Prepared in cooperation with the Minnesota Pollution Control Agency

\title{
Geomorphic Responses of Duluth-Area Streams to the June 2012 Flood, Minnesota
}
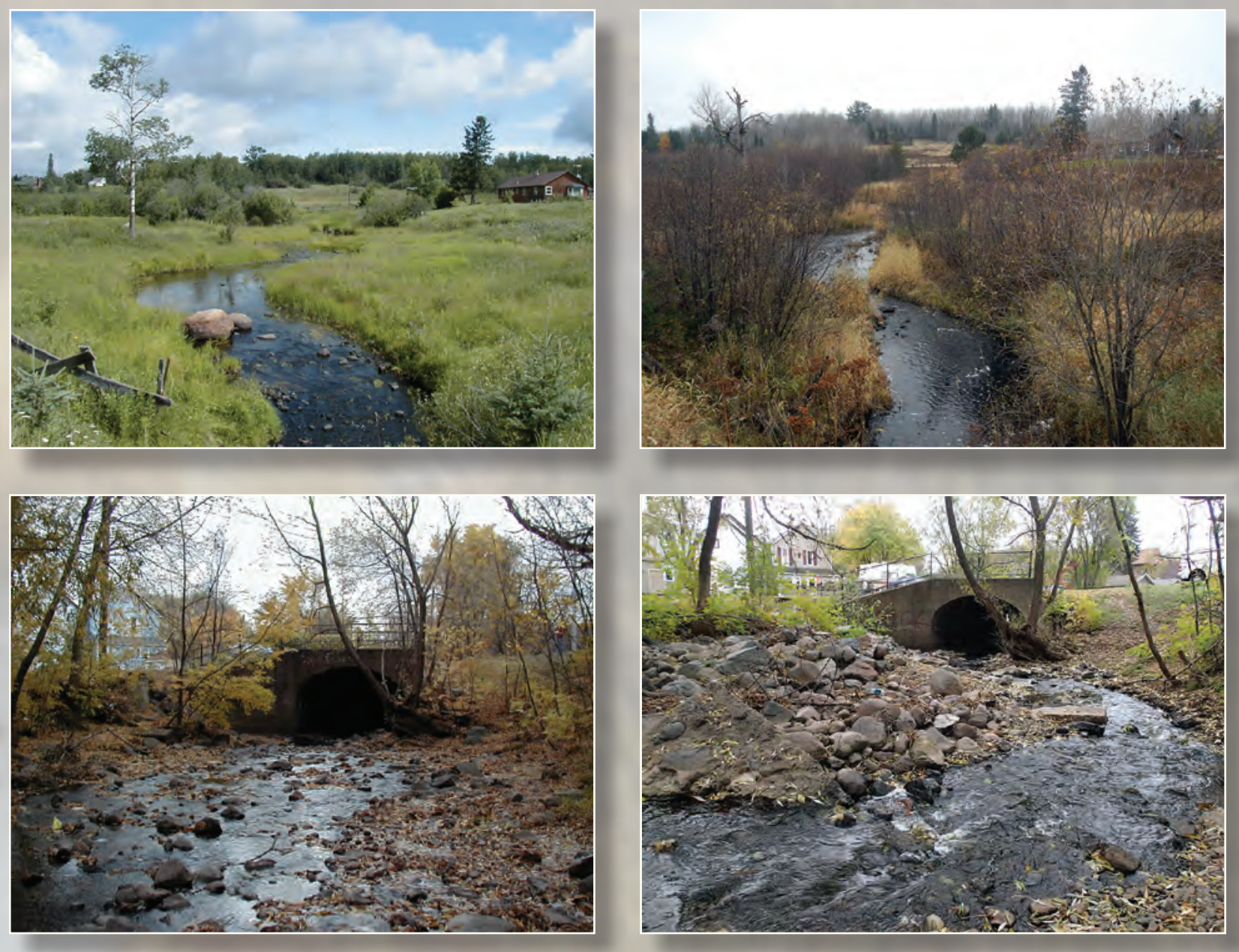

Scientific Investigations Report 2016-5104

U.S. Department of the Interior

U.S. Geological Survey 
Cover. Top photographs: Upper main stem, Lester River, slope 0.3-1.0 percent, no valley. Left: Photograph by Kathy Lee, U.S. Geological Survey, July 31, 2003.

Right: Photograph by Christiana Czuba, U.S. Geological Survey, October 30, 2013.

Bottom photographs: Lower main stem, Miller Creek, slope 0.3-1.0 percent, entrenched valley. Left: Photograph by Kathy Lee, U.S. Geological Survey, October 22, 2003.

Right: Photograph by Christiana Czuba, U.S. Geological Survey, October 29, 2013. 


\section{Geomorphic Responses of Duluth- Area Streams to the June 2012 Flood, Minnesota}

By Faith A. Fitzpatrick, Christopher A. Ellison, Christiana R. Czuba, Benjamin M.

Young, Molly M. McCool, and Joel T. Groten

Prepared in cooperation with the Minnesota Pollution Control Agency

Scientific Investigations Report 2016-5104 


\title{
U.S. Department of the Interior SALLY JEWELL, Secretary
}

\section{U.S. Geological Survey Suzette M. Kimball, Director}

\author{
U.S. Geological Survey, Reston, Virginia: 2016
}

For more information on the USGS - the Federal source for science about the Earth, its natural and living resources, natural hazards, and the environment—visit http://www.usgs.gov or call 1-888-ASK-USGS.

For an overview of USGS information products, including maps, imagery, and publications, visit http://store.usgs.gov.

Any use of trade, firm, or product names is for descriptive purposes only and does not imply endorsement by the U.S. Government.

Although this information product, for the most part, is in the public domain, it also may contain copyrighted materials as noted in the text. Permission to reproduce copyrighted items must be secured from the copyright owner.

Suggested citation:

Fitzpatrick, F.A., Ellison, C.A., Czuba, C.R., Young, B.M., McCool, M.M., and Groten, J.T., 2016, Geomorphic responses of Duluth-area streams to the June 2012 flood, Minnesota: U.S. Geological Survey Scientific Investigations Report 2016-5104, 53 p. with appendixes, http://dx.doi.org/10.3133/sir20165104.

ISSN 2328-0328 (online) 


\section{Contents}

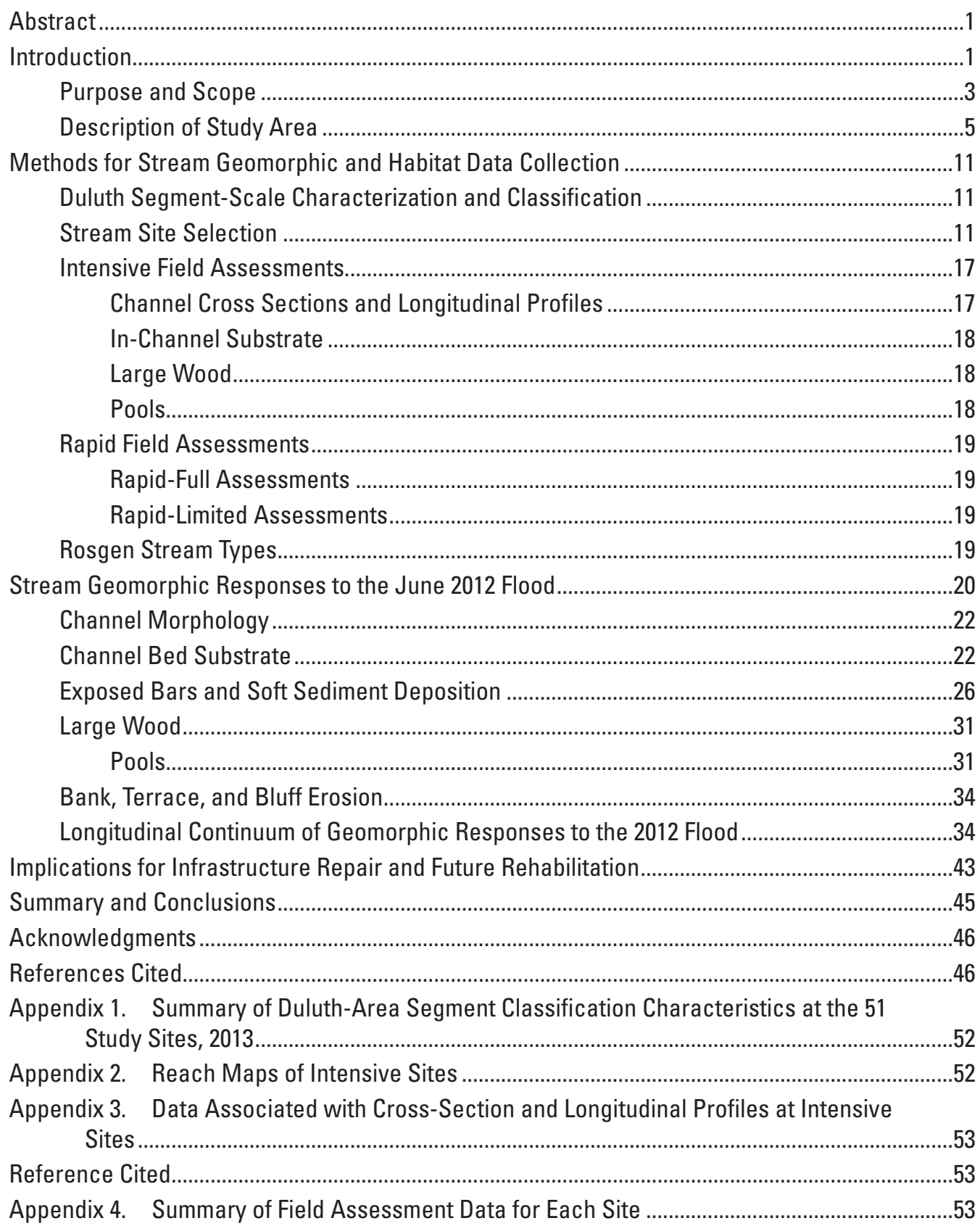




\section{Figures}

1. Map showing locations of 51 sites visited in 2013 as part of a flood geomorphic assessment of streams after the June 2012 flood in the Duluth, Minnesota, area ...........2

2. Map showing distribution of 2-day rainfall totals for 7 a.m. Central Daylight Time June 19 through 7 a.m. Central Daylight Time June 21, 2012.

3. Graph showing streamflow hydrograph for Knife River near Two Harbors, Minnesota for May 28 through July 27, 2012.

4. Diagrams of typical convex-up longitudinal profiles of altitude changes of Duluth-area streams from headwaters to rivermouths at Lake Superior with overlays.

5. Maps showing geomorphic segment classification for Duluth-area streams, Minnesota, overlain with 2013 geomorphic assessment sites

6. Graphs showing valley development and valley types along a longitudinal continuum

7. Map showing bedrock geology of the Duluth, Minnesota, area 15

8. Map showing surficial geology and geomorphology of the Duluth, Minnesota, area...

9. Diagram showing Rosgen Level II stream classification key

10. Maps showing stream channel succession and adjustment scenarios.........................21

11. Graphs showing overlays of 2003-4 and 2013 channel cross sections in riffles and runs at three sites in the Duluth, Minnesota, area..

12. Graphs showing relations between post-2012 flood bankfull channel characteristics for Duluth-area streams in 2013

13. Graph showing median particle size by Duluth segment-scale classification category for intensive and rapid-full sites, 2013.

14. Graphs showing cumulative frequency plots of substrate particle size at 2013 intensive sites in the Duluth, Minnesota, area grouped by Duluth segment-scale classification category

15. Graphs showing comparison of pebble count data in overlapping riffles, 2003-4 to 2013 .

16. Graphs showing percentage of reach area for 2013 intensive sites in the Duluth, Minnesota, area.....

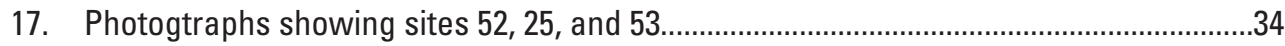

18. Graphs showing large wood per 150-meter reach length at intensive sites...................35

19. Graphs showing comparison of pool frequency and function per 150-meter reach length at intensive sites in the Duluth, Minnesota, area.

21. Photographs showing comparison of erosion at selected sites in the Duluth, Minnesota, area

20. Graph showing area of eroding banks, terraces, and bluffs for 2013 intensive sites in the Duluth, Minnesota, area.

22. Longitudinal profiles with comparison photographs showing effects from the 2012 flood

23. Photographs showing large wood accumulation along Mission Creek after the 2012 flood

24. Map showing overlay of roads in the Duluth, Minnesota, area with 2003-4 segment-scale classification by geomorphic sensitivity to disturbance. 


\section{Tables}

1. Geomorphic assessment sites in selected basins in the Duluth, Minnesota, area, 2013

2. Geomorphic segment-scale classification for streams in the Duluth, Minnesota, area with summaries of slopes, geologic settings, valley types, channel types, dominant geomorphic processes in 2003, geomorphic responses to the June 2012 flood, and Rosgen stream types.

3. Summary of post-2012 dominant geomorphic processes and Rosgen Level II stream types for eight intensive sites with overlapping data from 2003-4 geomorphic assessments.

4. Slope, channel morphology, and substrate characteristics related to Duluth segment-scale classification categories for intensive, rapid-full, and rapid-limited geomorphic assessment sites.

5. Observed correspondence between the Duluth segment-scale classification and Duluth channel types and Rosgen Level II stream types for sites sampled in 2013 based on segment-averaged slope

\section{Conversion Factors}

[International System of Units to U.S. customary units]

\begin{tabular}{lcl}
\hline \multicolumn{1}{c}{ Multiply } & By & \multicolumn{1}{c}{ To obtain } \\
\hline centimeter $(\mathrm{cm})$ & Length & inch (in.) \\
millimeter $(\mathrm{mm})$ & 0.3937 & inch (in.) \\
meter $(\mathrm{m})$ & 0.03937 & yard (yd) \\
meter $(\mathrm{m})$ & 1.094 & foot (ft) \\
kilometer $(\mathrm{km})$ & 3.281 & mile (mi) \\
kilometer $(\mathrm{km})$ & 0.6214 & mile, nautical $(\mathrm{nmi})$ \\
\hline & 0.5400 & \\
\hline square meter $\left(\mathrm{m}^{2}\right)$ & Area & acre \\
square kilometer $\left(\mathrm{km}^{2}\right)$ & 0.0002471 & acre \\
square centimeter $\left(\mathrm{cm}^{2}\right)$ & 247.1 & square foot $\left(\mathrm{ft}^{2}\right)$ \\
square meter $\left(\mathrm{m}^{2}\right)$ & 0.001076 & square foot $\left(\mathrm{ft}^{2}\right)$ \\
square kilometer $\left(\mathrm{km}^{2}\right)$ & 10.76 & square mile $\left(\mathrm{mi}^{2}\right)$ \\
\hline & 0.3861 & \\
\hline cubic meter $\left(\mathrm{m}^{3}\right)$ & Volume & cubic foot $\left(\mathrm{ft}^{3}\right)$ \\
cubic meter $\left(\mathrm{m}^{3}\right)$ & 35.31 & cubic yard $\left(\mathrm{yd}^{3}\right)$ \\
\hline & 1.308 & acre-foot per day $(\mathrm{acre}-\mathrm{ft} / \mathrm{d})$ \\
\hline cubic meter per second $\left(\mathrm{m}^{3} / \mathrm{s}\right)$ & Flow rate & \\
\hline
\end{tabular}

Vertical coordinate information is referenced to the National Geodetic Vertical Datum of 1929 (NGVD 29) or the North American Vertical Datum of 1988 (NAVD 88).

Horizontal coordinate information is referenced to the North American Datum of 1983 (NAD 83).

Altitude, as used in this report, refers to distance above the vertical datum. 


\author{
Abbreviations \\ $\pm \quad$ plus or minus \\ DEM digital elevation model \\ GIS geographic information system \\ GNSS global navigation satellite system \\ GPS global positioning system \\ lidar light detection and ranging \\ RTN real-time network \\ USGS U.S. Geological Survey \\ WSC Water Science Center
}




\title{
Geomorphic Responses of Duluth-Area Streams to the June 2012 Flood, Minnesota
}

\author{
By Faith A. Fitzpatrick, Christopher A. Ellison, Christiana R. Czuba, Benjamin M. Young, Molly M. McCool, and \\ Joel T. Groten
}

\section{Abstract}

In 2013, the U.S. Geological Survey, in cooperation with the Minnesota Pollution Control Agency, completed a geomorphic assessment of 51 Duluth-area stream sites in 20 basins to describe and document the stream geomorphic changes associated with the June 2012 flood. Heavy rainfall caused flood peaks with annual exceedance probabilities of less than 0.002 (flood recurrence interval of greater than 500 years) on large and small streams in and surrounding the Duluth area. A geomorphic segment-scale classification previously developed in 2003-4 by the U.S. Geological Survey for Duluth-area streams was used as a framework to characterize the observed flood-related responses along a longitudinal continuum from headwaters to rivermouths at Lake Superior related to drainage network position, slope, geologic setting, and valley type. Field assessments in 2013 followed and expanded on techniques used in 2003-4 at intensive and rapid sites. A third level of assessment was added in 2013 to increase the amount of quantitative data at a subset of 2003-4 rapid sites. Characteristics of channel morphology, channel bed substrate, exposed bars and soft sediment deposition, large wood, pools, and bank erosion were measured; and repeat photographs were taken. Additional measurements in 2013 included identification of Rosgen Level II stream types. The comparative analyses of field data collected in 2003-4 and again in 2013 indicated notable geomorphic changes, some of them expected and others not. As expected, in headwaters with gently sloping wetland segments, geomorphic changes were negligible (little measured or observed change). Downstream, middle main stems generally had bank and bluff erosion and bar formation as expected. Steep bedrock sites along middle and lower main stems had localized bank and bluff erosion in short sections with intermittent bedrock. Lower main stem and alluvial sites had bank erosion, widening, gravel bar deposition, and aggradation. Bar formation and accumulation of gravel was more widespread than expected among all main stems, especially for sites upstream and downstream from channel constrictions from road crossings, or even steep sites with localized, more gently sloping sections. Decreases in large wood and pools also were observed throughout the longitudinal continuum of main-stem sites, with immediate implications for fish and benthic invertebrate aquatic habitat. Whether or not the geomorphic conditions will return to their preflood condition depends on the location along the longitudinal continuum. The amount of large wood and pools may return after more moderate floods, whereas bars with coarse material may remain in place, locally altering flow direction and causing continued bank erosion. Results from this study can be used by local managers in postflood reconstruction efforts and provide baseline information for continued monitoring of geomorphic responses to the June 2012 flood.

\section{Introduction}

In 2003-4, the U.S. Geological Survey (USGS), in cooperation with the city of Duluth, Minnesota (Minn.), collected a suite of geomorphic data for 48 streams that would be fundamental for quantifying altered morphology resulting from an extreme flood that hit the Duluth area in June 2012 (hereafter referred to as the 2012 flood). As part of the postflood cleanup, the USGS, in cooperation with the Minnesota Pollution Control Agency, documented geomorphic changes to Duluth-area streams by revisiting sites in 2013 (fig. 1) that were part of the 2003-4 geomorphic assessment and classification study (Fitzpatrick and others, 2006). The goals of the 2003-4 study were to characterize and classify Duluth-area streams in terms of their geomorphic characteristics and processes and potential responses to a basin-wide hydrologic disturbance, such as urbanization. The 2003-4 geomorphic segment-scale classification for Duluth-area streams was used as a framework to characterize the observed flood-related changes in channel morphology and sediment dynamics along a longitudinal continuum of drainage network position, slope, geologic setting, and valley type. An extreme flood like the 2012 flood represents a one-time episodic disturbance to flows; thus, there is some expectation that channel morphology would return to the preflood conditions after several floods. Extensive erosion and deposition associated with the 2012 flood, however, may affect long-term morphological characteristics and sediment transport. 


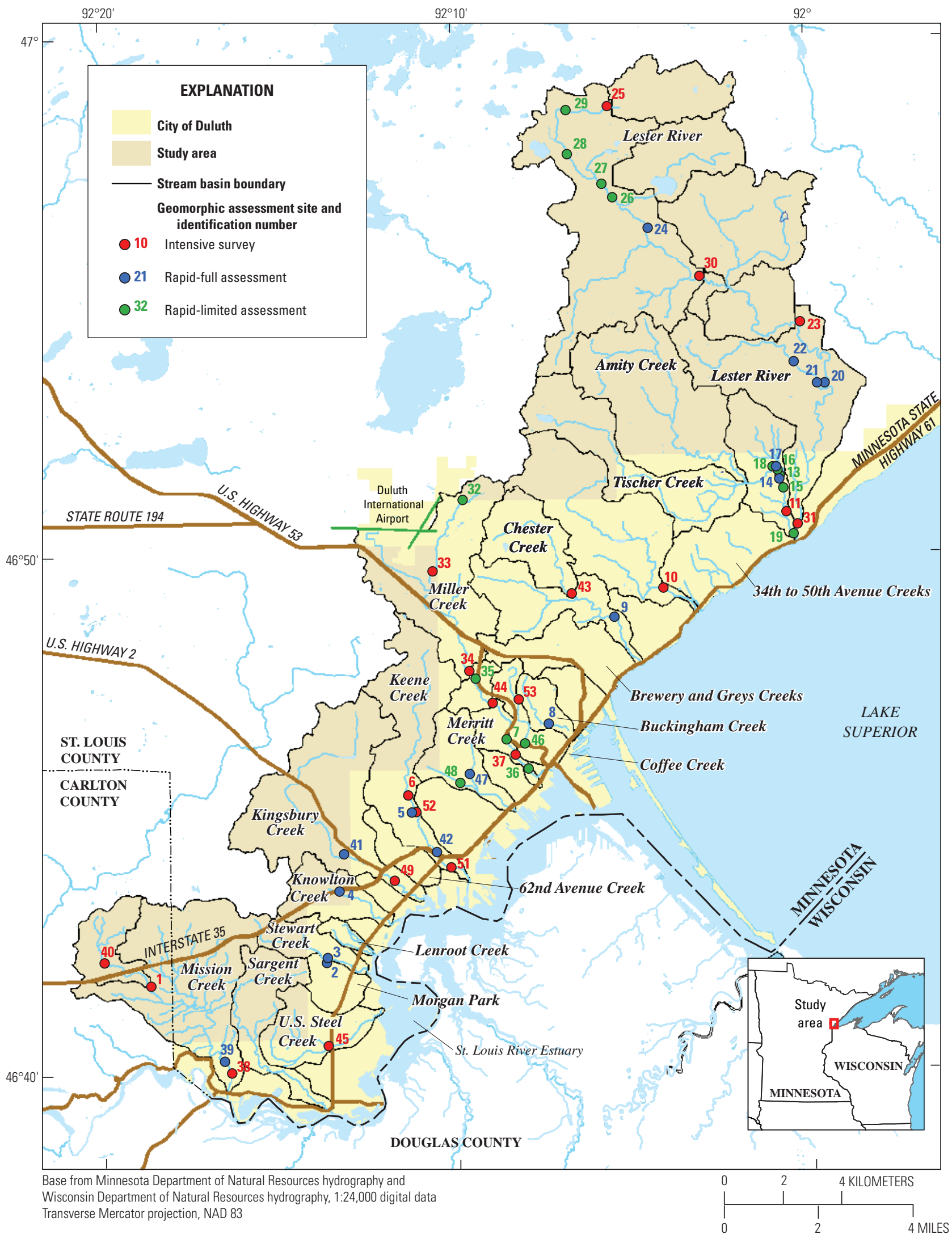

Figure 1. Locations of 51 sites visited in 2013 as part of a flood geomorphic assessment of streams after the June 2012 flood in the Duluth, Minnesota, area. 
Rainfall totals in the Duluth area for the June 19-21, 2012, flood event ranged from 15 centimeters $(\mathrm{cm})$ to greater than $20 \mathrm{~cm}$ (fig. 2; Czuba and others, 2012). This resulted in flood peaks with annual exceedance probabilities of less than 0.002 (flood recurrence interval of greater than 500 years) on large and small streams in and surrounding the Duluth area, including the Knife River. The flood hydrograph for the Knife River near Two Harbors, Minn. (USGS streamgage 04015330) illustrates the building effects of runoff related to smaller precipitation events in the days before the flood and the quick rise in flows for the main flood event (fig. 3).

The 2013 geomorphic assessments expanded the field techniques used in the 2003-4 assessments and kept the Duluth geomorphic segment-scale classification framework developed by Fitzpatrick and others (2006) as a context for describing the geomorphic changes from the 2012 flood (tables 1 and 2). All but 1 of the 2003-4 sites were revisited, and 3 new sites were added for a total of 51 sites spanning 20 stream basins. Several of the sites are within the same larger basins, including Lester River, Miller Creek, and Mission Creek. Additional quantitative measurements were added to the field surveys in 2013, including measurements needed to calculate the Rosgen Level II stream type (Rosgen, 1994, 1996).

The 2003-4 Duluth segment-scale classification was adapted from a channel classification and approach for prediction of stream geomorphic processes and sediment dynamics along a longitudinal continuum developed by Montgomery and Buffington (1993, 1997, 1998). The Duluth segment-scale classification has 15 segment categories with slope ranging from less than 0.3 to greater than 4 percent (figs. $4 \mathrm{~A}$ and 5; table 2). The main difference between the Duluth segmentscale classification and others that are more generic is that it reflects the convex-up longitudinal profile for Duluth-area streams, rather than the usual concave-up longitudinal profile (figs. 4B and 4C). Similar to other tributaries to Lake Superior, the convex-up longitudinal profile reflects the combined effects of glacial landforms and bedrock topography on stream slope, valley development, and stream erodibility (Fitzpatrick and others, 1998, 2015). Major geomorphic processes follow a predictable pattern along the longitudinal profile, such as incision, bluff erosion, bank erosion, widening, lateral migration, overbank sedimentation, bar deposition, and aggradation. Having the steepest slopes in the middle of basins instead of in the headwaters affects the usual distribution of expected channel bedforms and channel morphology (figs. 4B and 4C).

The longitudinal continuum of four major valley typesno valley development, confined V-shaped valley, unconfined valley with entrenched meanders, and unconfined valley with alluvial meanders-helps to predict zones of erosion, transfer, and deposition (fig. 6). Instead of steep confined channels in headwaters that would usually be the source of sediment through gullying and headcutting, Duluth-area headwater channels originating on glacial deposits have gently sloped, unconfined channels in wetlands. Middle main stems with entrenched valleys through Lake Superior-related paleo shoreline deposits provide the opportunity for large amounts of direct sediment source and delivery through bluff erosion along valley sides in steep sites (Fitzpatrick and others, 1998, 2015). Steep sites flowing on bedrock continue sediment transport to lower main stems. Lower main stems and alluvial sites with gentle slopes and unconfined valleys in the vicinity of Lake Superior are mainly depositional.

The Rosgen stream classification scheme (fig. 4C; Rosgen, 1985, 1994, 1996) was incorporated into the post-2012 flood study because of its common use among Minnesota State agencies as a standardized communication tool and aid in river restoration projects (Karl Koller, Minnesota Department of Natural Resources, oral commun., September 9, 2013). The combination of the Duluth segment-scale classification and the Rosgen Level II stream type classification provided a dualpurpose framework for discussing river geomorphology and links to the underlying geomorphic processes related to the 2012 flood.

\section{Purpose and Scope}

The purpose of this report is to provide an update on geomorphic conditions and processes in streams in the vicinity of Duluth, Minn. (fig. 1) after the 2012 flood and compare those results with preflood 2003-4 conditions. Specifically, the report aims to do the following: (1) quantify geomorphic responses to the 2012 flood at sites previously sampled in 2003-4; (2) summarize 2012 flood-related responses in terms of the broader geomorphic setting using the Duluth segmentscale classification; and (3) describe how relations among channel processes, sediment dynamics, and geomorphic setting can be used to assist managers in postflood reconstruction activities and stream restoration.

The scope of the report includes the following:

- Descriptions of the updated methods used for stream geomorphic assessments, including intensive, rapidfull, and rapid-limited assessments, and Rosgen Level II stream classification;

- Descriptions of the geomorphic responses to the 2012 flood of the studied sites, set in the context of their geomorphic and geologic settings and longitudinal profile;

- Comparisons of geomorphic responses to the 2012 flood among Duluth segment-scale classification categories and Rosgen Level II stream types, and channel bedforms; and

- Implications of the results in terms of infrastructure repair and future rehabilitation. 


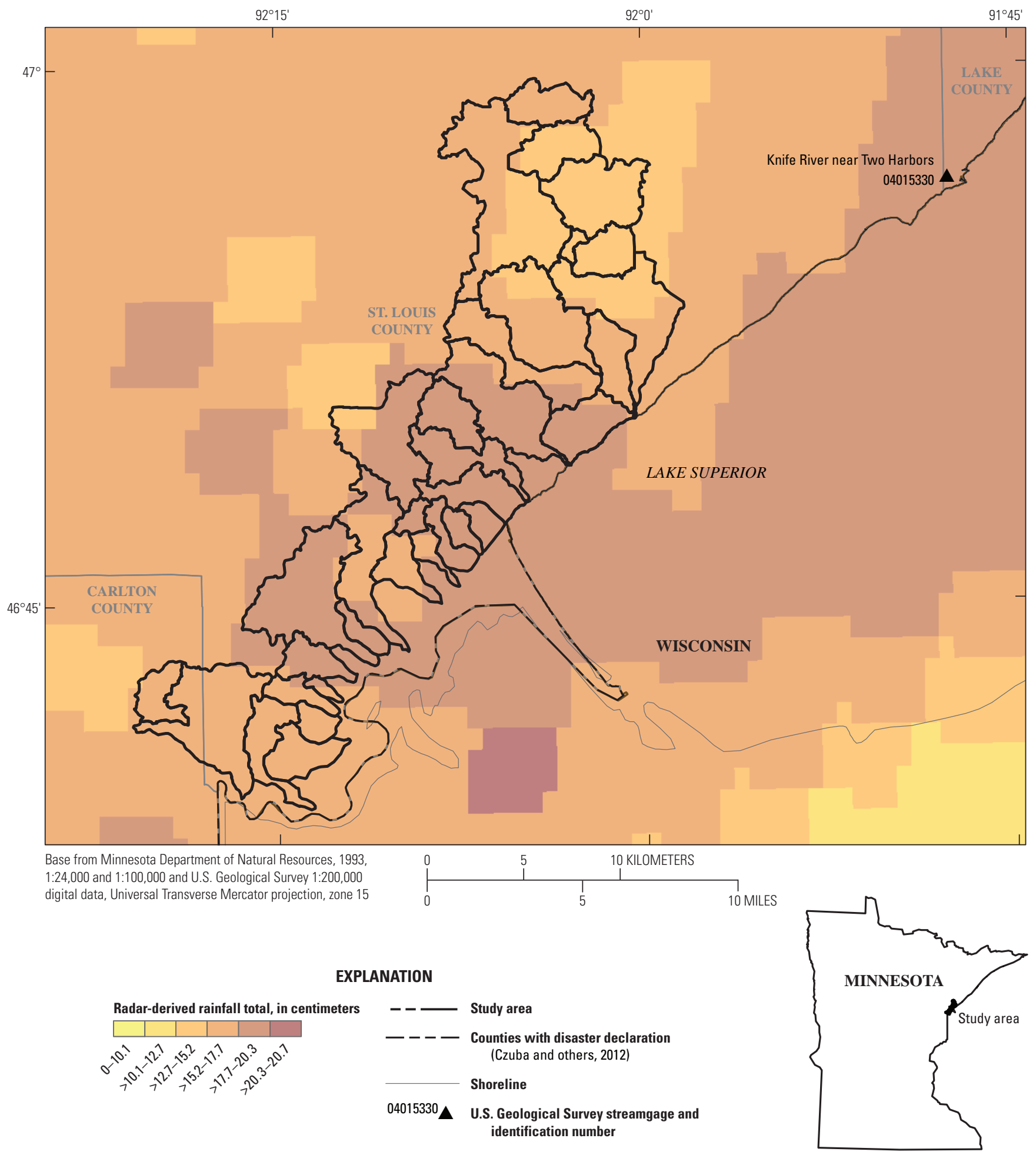

Figure 2. Distribution of 2-day rainfall totals for 7 a.m. Central Daylight Time June 19 through 7 a.m. Central Daylight Time June 21, 2012 (Czuba and others, 2012). Rainfall data provided by Steve Gohde and Diane Cooper (National Weather Service, written commun., 2012). 


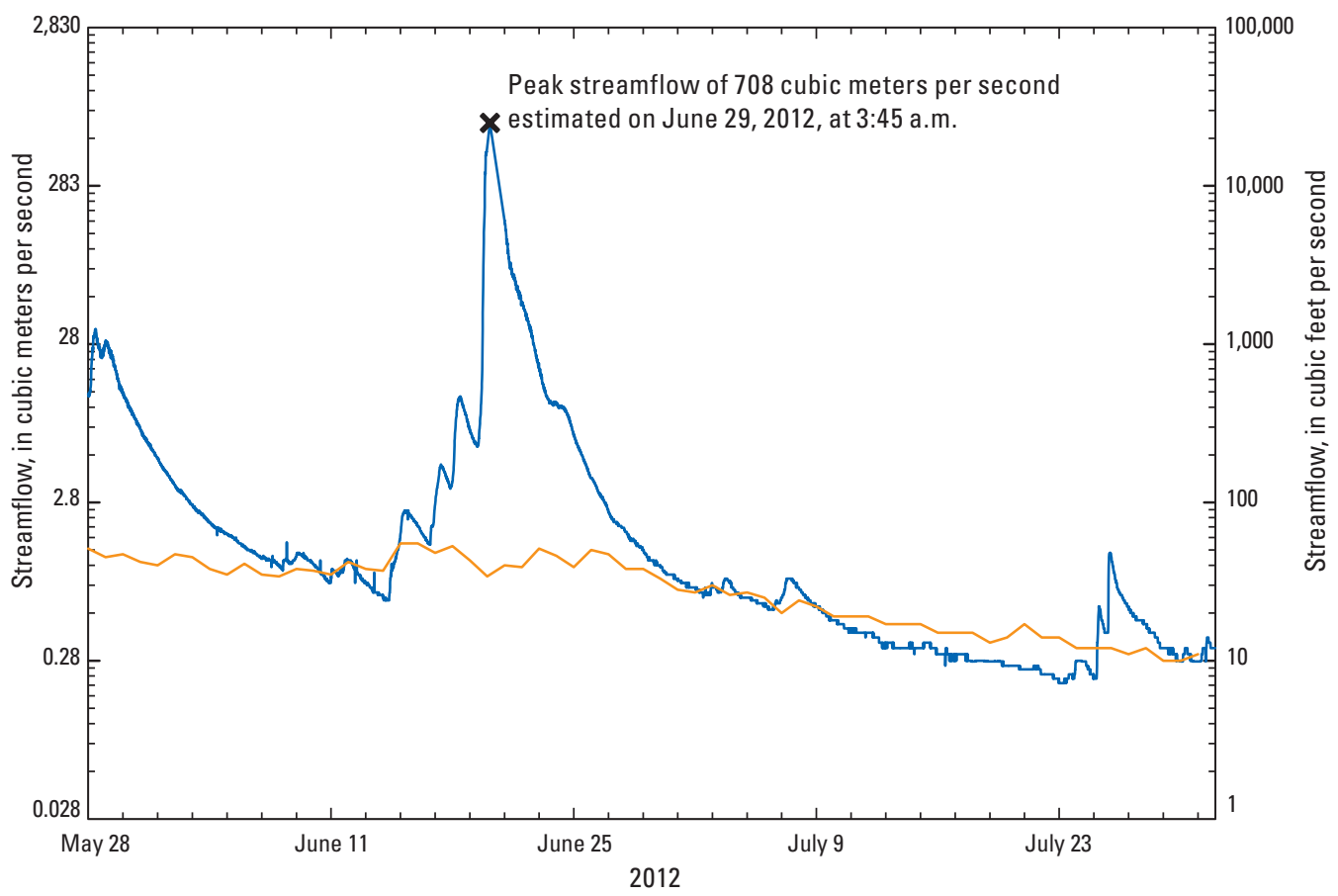

Figure 3. Streamflow hydrograph for Knife River near Two Harbors, Minnesota (U.S. Geological Survey streamgage 04015330) for May 28 through July 27, 2012. (Data from U.S. Geological Survey, 2013.)

\section{EXPLANATION}

\section{Description of Study Area}

Streams in the Duluth area generally flow perpendicular to the shoreline of Lake Superior, from northwest to southeast (fig. 1). Altitudes of basins range from about 430 meters (m) (above the National Geodetic Vertical Datum of 1929) in the headwaters to $183.5 \mathrm{~m}$ at Lake Superior. Most of the altitude change (topographic relief) happens along the middle and lower main stems as streams flow over bedrock bluffs and outcrops near the shore of Lake Superior.

Bedrock is at or near the surface in the Duluth area and mainly consists of Proterozoic volcanic and igneous rocks, intrusions, and sedimentary rocks (fig. 7; Miller and others, 2001). Nomenclature for geologic names of bedrock units follows that of the Minnesota Geological Survey. Bedrock type and faulting affects the pattern and density of the stream networks. Right-angle bends in the channel and stream confluences are indicative of underlying contacts between bedrock units or faulting. The Duluth Complex of the Keweenawan Supergroup and miscellaneous other intrusive rocks form a prominent steep rocky bluff that parallels the shoreline of the St. Louis River Estuary and Lake Superior. The Duluth segment-scale classification used four categories of bedrock - sedimentary rocks in the southwest part of the Duluth area, mainly in the Mission Creek Basin; the Duluth Complex gabbro and other intrusive rocks in the center part of the study area; felsic and mafic volcanic rocks in the northeastern part of the study area, and intrusions in the volcanic rocks.
Quaternary (Holocene and Late Wisconsinan) surficial deposits in the Duluth area are generally in the upper parts of most of the basins but are thin or absent from the middle main stems where bedrock is exposed at the land surface (fig. 8). Glacial deposits in the basins are from the Late Wisconsinan Lake Superior Lobe (Goebel and others, 1983). Glacial deposits in the headwaters and the upper parts of the basins above an altitude of about $365 \mathrm{~m}$ consist of supraglacial drift composed of sandy loamy till of the Cromwell Formation (Goebel and others, 1983; University of Minnesota-Duluth Geology Department and others, 1997; Hobbs, 2004). Later glacial readvances resulted in the deposition of silty loam till of the Lakewood Member, clay loam to silty clay loam till of the Moose Lake Member, and clay till of the informally named Knife River member, all of the Barnum Till Formation (Hobbs, 2004). In the Duluth area, the Lakewood Member is at altitudes from about 350 to $365 \mathrm{~m}$, the Moose Lake Member is at altitudes from about 335 to 350 m, and the Knife River member is at altitudes up to about $320 \mathrm{~m}$.

Shoreline features from wave action and beaches are present at altitudes from 311 to $335 \mathrm{~m}$ and were caused by multiple phases of glacial Lake Duluth in the southwest part of Lake Superior during glacial retreats in the Late Wisconsinan and early Holocene (Leverett, 1929; Hobbs, 2004).

Land cover in the Duluth area consists of a mix of mainly urban land (developed/barren), forest, and shrub (Minnesota Department of Natural Resources, 2002). Urban land is concentrated in Duluth and along transportation corridors leading into Duluth (Fitzpatrick and others, 2006). Marsh, lowland 
Table 1. Geomorphic assessment sites in selected basins in the Duluth, Minnesota, area, 2013. See table 2 for description of segment categories.

[Locations are for the downstream end of the reaches. Segment categories based on Fitzpatrick and others (2006). USGS, U.S. Geological Survey; ID, identification; NAD 83, North American Datum of 1983; $\mathrm{mi}^{2}$, square mile; $\mathrm{km}^{2}$, square kilometer, $\mathrm{n} / \mathrm{a}$, not applicable]

\begin{tabular}{|c|c|c|c|c|c|c|c|c|c|}
\hline $\begin{array}{c}\text { Geomorphic } \\
\text { assessment } \\
\text { site ID } \\
\text { number }^{1} \\
\text { (fig. 1) }\end{array}$ & Site name & $\begin{array}{l}\text { Latitude } \\
\text { (north) } \\
\text { (NAD 83) }\end{array}$ & $\begin{array}{l}\text { Longitude } \\
\text { (west) } \\
\text { (NAD 83) }\end{array}$ & $\begin{array}{c}\text { Drainage } \\
\text { area } \\
\left(\mathrm{mi}^{2}\right)\end{array}$ & $\begin{array}{c}\text { Drainage } \\
\text { area } \\
\left(\mathrm{km}^{2}\right)\end{array}$ & $\begin{array}{c}2003 \\
\text { Assessment } \\
\text { type }\end{array}$ & $\begin{array}{c}2013 \\
\text { Assessment } \\
\text { type } \\
\text { (fig. 1) }\end{array}$ & $\begin{array}{c}2013 \\
\text { Duluth segment- } \\
\text { scale } \\
\text { classification } \\
\text { category } \\
\text { (fig. 5) }\end{array}$ & $\begin{array}{c}2013 \\
\text { Rosgen } \\
\text { Level II } \\
\text { stream type } \\
\text { (fig. 9) }\end{array}$ \\
\hline 1 & Mission Creek at Stenman Road & $46^{\circ} 41^{\prime} 43^{\prime \prime}$ & $92^{\circ} 18^{\prime} 42^{\prime \prime}$ & 2.40 & 6.22 & Intensive & Intensive & M1 & E4 \\
\hline 2 & Stewart Creek Tributary at Skyline Road & $46^{\circ} 42^{\prime} 07^{\prime \prime}$ & $92^{\circ} 13^{\prime} 43^{\prime \prime}$ & 0.14 & 0.36 & Rapid & Rapid full & BT & АЗ + \\
\hline 3 & Stewart Creek at Skyline Road & $46^{\circ} 42^{\prime} 13^{\prime \prime}$ & $92^{\circ} 13^{\prime} 41^{\prime \prime}$ & 1.04 & 2.69 & Rapid & Rapid full & B & АЗ + \\
\hline 4 & Knowlton Creek at South Boundary Access Road & $46^{\circ} 43^{\prime} 30^{\prime \prime}$ & $92^{\circ} 13^{\prime} 20^{\prime \prime}$ & 1.39 & 3.60 & Rapid & Rapid full & B & ВЗа \\
\hline 5 & Keene Creek Tributary at Skyline Road/Getchell Road & $46^{\circ} 45^{\prime} 01^{\prime \prime}$ & $92^{\circ} 11^{\prime} 17^{\prime \prime}$ & 0.15 & 0.39 & Rapid & Rapid full & $\mathrm{BT}$ & A3 \\
\hline 6 & Keene Creek at Skyline Road & $46^{\circ} 45^{\prime} 21^{\prime \prime}$ & $92^{\circ} 11^{\prime} 21^{\prime \prime}$ & 4.15 & 10.8 & Rapid & Intensive & M1 & B4c \\
\hline 7 & Miller Creek at Skyline Road & $46^{\circ} 46^{\prime} 25^{\prime \prime}$ & $92^{\circ} 08^{\prime} 35^{\prime \prime}$ & 9.36 & 24.2 & Drive by & Rapid limited & B & A3 \\
\hline 8 & Buckingham Creek at Skyline Road & $46^{\circ} 46^{\prime} 43^{\prime \prime}$ & $92^{\circ} 07^{\prime} 23^{\prime \prime}$ & 0.75 & 1.94 & Rapid & Rapid full & B & $\mathrm{A} 1 \mathrm{a}+$ \\
\hline 9 & Chester Creek at Skyline Road & $46^{\circ} 48^{\prime} 46^{\prime \prime}$ & $92^{\circ} 05^{\prime} 30^{\prime \prime}$ & 6.38 & 16.5 & Rapid & Rapid full & M2 & B2 \\
\hline 10 & Tischer Creek at Skyline Road/Vermillion Road & $46^{\circ} 49^{\prime} 20^{\prime \prime}$ & $92^{\circ} 04^{\prime} 07^{\prime \prime}$ & 6.99 & 18.1 & Drive by & Intensive & B & B2a \\
\hline 11 & Amity Creek at Occidental Road, Lester Park & $46^{\circ} 50^{\prime} 39^{\prime \prime}$ & $92^{\circ} 00^{\prime} 37^{\prime \prime}$ & 16.5 & 42.7 & Rapid & Intensive & L1 & B3c \\
\hline 13 & $\begin{array}{l}\text { Amity Creek at Occidental Road, Amity Creek Park, } \\
\text { Number } 2\end{array}$ & $46^{\circ} 51^{\prime} 14^{\prime \prime}$ & $92^{\circ} 00^{\prime} 41^{\prime \prime}$ & 15.9 & 41.2 & Rapid & Rapid limited & L1 & B2c \\
\hline 14 & $\begin{array}{l}\text { Amity Creek at Occidental Road, Amity Creek Park, } \\
\text { Number } 3\end{array}$ & $46^{\circ} 51^{\prime} 25^{\prime \prime}$ & $92^{\circ} 00^{\prime} 48^{\prime \prime}$ & 15.9 & 41.2 & Rapid & Rapid full & $\mathrm{L} 2$ & B3 \\
\hline 15 & $\begin{array}{l}\text { Amity Creek at Occidental Road, Amity Creek Park, } \\
\text { Number } 4\end{array}$ & $46^{\circ} 51^{\prime} 29^{\prime \prime}$ & $92^{\circ} 00^{\prime} 47^{\prime \prime}$ & 15.8 & 40.9 & Rapid & Rapid limited & L1 & B3c \\
\hline 16 & $\begin{array}{l}\text { Amity Creek at Occidental Road, Amity Creek Park, } \\
\text { Number } 5\end{array}$ & $46^{\circ} 51^{\prime} 35^{\prime \prime}$ & $92^{\circ} 00^{\prime} 51^{\prime \prime}$ & 15.8 & 40.9 & Rapid & Rapid limited & L1 & B2c \\
\hline 17 & $\begin{array}{l}\text { Amity Creek at Occidental Road, Amity Creek Park, } \\
\text { Number } 6\end{array}$ & $46^{\circ} 51^{\prime} 39^{\prime \prime}$ & $92^{\circ} 00^{\prime} 53^{\prime \prime}$ & 14.0 & 36.3 & Rapid & Rapid full & B & B1a \\
\hline 18 & Amity Creek at Skyline Road & $46^{\circ} 51^{\prime} 40^{\prime \prime}$ & $92^{\circ} 00^{\prime} 59^{\prime \prime}$ & 14.0 & 36.3 & Rapid & Rapid limited & L1 & B1c \\
\hline 19 & Lester River at Superior Street & $46^{\circ} 50^{\prime} 21^{\prime \prime}$ & $92^{\circ} 00^{\prime} 25^{\prime \prime}$ & 36.5 & 94.5 & Rapid & Rapid limited & L2 & B1 \\
\hline 20 & Lester River at Strand Road & $46^{\circ} 53^{\prime} 16^{\prime \prime}$ & $91^{\circ} 59^{\prime} 29^{\prime \prime}$ & 29.6 & 76.7 & Rapid & Rapid full & M1 & $\mathrm{C} 4$ \\
\hline 21 & Lester River Tributary at Strand Road & $46^{\circ} 53^{\prime} 16^{\prime \prime}$ & $91^{\circ} 59^{\prime} 42^{\prime \prime}$ & 2.73 & 7.07 & Drive by & Rapid full & M1 & C4 \\
\hline 22 & Lester River Tributary at Beyer Road & $46^{\circ} 53^{\prime} 41^{\prime \prime}$ & $92^{\circ} 00^{\prime} 21^{\prime \prime}$ & 2.46 & 6.37 & Rapid & Rapid full & M1 & B4c \\
\hline 23 & Lester River at North Tischer Road & $46^{\circ} 54^{\prime} 27^{\prime \prime}$ & $92^{\circ} 00^{\prime} 20^{\prime \prime}$ & 28.5 & 73.8 & Intensive & Intensive & M.3 & F4 \\
\hline 24 & Lester River at Hwy 43, Lismore Road & $46^{\circ} 56^{\prime} 18^{\prime \prime}$ & $92^{\circ} 04^{\prime} 26^{\prime \prime}$ & 12.6 & 32.6 & Rapid & Rapid full & W.3 & C5 \\
\hline 25 & Lester River at Arnold Road, Number 1 & $46^{\circ} 58^{\prime} 40^{\prime \prime}$ & $92^{\circ} 05^{\prime} 26^{\prime \prime}$ & 2.91 & 7.54 & Intensive & Intensive & W & E5 \\
\hline
\end{tabular}


Table 1. Geomorphic assessment sites in selected basins in the Duluth, Minnesota, area, 2013. See table 2 for description of segment categories. -Continued

[Locations are for the downstream end of the reaches. Segment categories based on Fitzpatrick and others (2006). USGS, U.S. Geological Survey; ID, identification; NAD 83, North American Datum of 1983; $\mathrm{mi}^{2}$, square mile; $\mathrm{km}^{2}$, square kilometer, n/a, not applicable]

\begin{tabular}{|c|c|c|c|c|c|c|c|c|c|}
\hline $\begin{array}{c}\text { Geomorphic } \\
\text { assessment } \\
\text { site ID } \\
\text { number } \\
\text { (fig. 1) }\end{array}$ & Site name & $\begin{array}{l}\text { Latitude } \\
\text { (north) } \\
\text { (NAD 83) }\end{array}$ & $\begin{array}{l}\text { Longitude } \\
\text { (west) } \\
\text { (NAD 83) }\end{array}$ & $\begin{array}{c}\text { Drainage } \\
\text { area } \\
\left(\mathrm{mi}^{2}\right)\end{array}$ & $\begin{array}{c}\text { Drainage } \\
\text { area } \\
\left(\mathrm{km}^{2}\right)\end{array}$ & $\begin{array}{c}2003 \\
\text { Assessment } \\
\text { type }\end{array}$ & $\begin{array}{c}2013 \\
\text { Assessment } \\
\text { type } \\
\text { (fig. 1) }\end{array}$ & $\begin{array}{c}2013 \\
\text { Duluth segment- } \\
\text { scale } \\
\text { classification } \\
\text { category } \\
\text { (fig. } 5 \text { ) }\end{array}$ & $\begin{array}{c}2013 \\
\text { Rosgen } \\
\text { Level II } \\
\text { stream type } \\
\text { (fig. 9) }\end{array}$ \\
\hline 26 & Lester River at Arnold Road, Number 2 & $46^{\circ} 56^{\prime} 54^{\prime \prime}$ & $92^{\circ} 05^{\prime} 26^{\prime \prime}$ & 8.29 & 21.5 & Rapid & Rapid limited & $\mathrm{W}$ & C5c- \\
\hline 27 & Lester River at Emerson Road & $46^{\circ} 57^{\prime} 10^{\prime \prime}$ & $92^{\circ} 05^{\prime} 44^{\prime \prime}$ & 7.07 & 18.3 & Rapid & Rapid limited & $\mathrm{W}$ & E5 \\
\hline 28 & Lester River at Howard Gnesen Road, Number 1 & $46^{\circ} 57^{\prime} 45^{\prime \prime}$ & $92^{\circ} 06^{\prime} 42^{\prime \prime}$ & 5.31 & 13.8 & Rapid & Rapid limited & W & $\mathrm{C} 4$ \\
\hline 29 & Lester River at Howard Gnesen Road, Number 2 & $46^{\circ} 58^{\prime} 36^{\prime \prime}$ & $92^{\circ} 06^{\prime} 43^{\prime \prime}$ & 3.87 & 10.0 & Rapid & Rapid limited & W & C5 \\
\hline 30 & Lester River at Highway 37, Jean Duluth Road & $46^{\circ} 55^{\prime} 18^{\prime \prime}$ & $92^{\circ} 02^{\prime} 54^{\prime \prime}$ & 19.4 & 50.2 & Intensive & Intensive & M.3 & F3 \\
\hline 31 & Lester River near Lester River Road & $46^{\circ} 50^{\prime} 32^{\prime \prime}$ & $92^{\circ} 00^{\prime} 21^{\prime \prime}$ & 36.4 & 94.3 & Intensive & Intensive & L1 & F3 \\
\hline 32 & Miller Creek at Ridgeview Road & $46^{\circ} 51^{\prime} 04^{\prime \prime}$ & $92^{\circ} 09^{\prime} 45^{\prime \prime}$ & 0.56 & 1.45 & Drive by & Rapid limited & W.3 & C5 \\
\hline 33 & Miller Creek at Swan Lake Road & $46^{\circ} 49^{\prime} 43^{\prime \prime}$ & $92^{\circ} 10^{\prime} 34^{\prime \prime}$ & 2.76 & 7.15 & Rapid & Intensive & W.3 & E5 \\
\hline 34 & Miller Creek upstream from Chambersburg Avenue & $46^{\circ} 47^{\prime} 46^{\prime \prime}$ & $92^{\circ} 09^{\prime} 37^{\prime \prime}$ & 7.91 & 20.5 & Intensive & Intensive & M.3 & $\mathrm{C} 4$ \\
\hline 35 & Miller Creek at Anderson Road & $46^{\circ} 47^{\prime} 36^{\prime \prime}$ & $92^{\circ} 09^{\prime} 26^{\prime \prime}$ & 8.18 & 21.2 & Intensive & Rapid limited & M1 & B3c \\
\hline 36 & Miller Creek between 2nd and 3rd Street and 26th Avenue & $46^{\circ} 45^{\prime} 51^{\prime \prime}$ & $92^{\circ} 07^{\prime} 58^{\prime \prime}$ & 9.83 & 25.5 & Rapid & Rapid limited & A & A3 \\
\hline 37 & Miller Creek at 10th Street & $46^{\circ} 46^{\prime} 15^{\prime \prime}$ & $92^{\circ} 08^{\prime} 23^{\prime \prime}$ & 9.39 & 24.3 & Rapid & Intensive & $\mathrm{B}$ & B3 \\
\hline 38 & Mission Creek at Highway 23 & $46^{\circ} 39^{\prime} 39^{\prime \prime}$ & $92^{\circ} 16^{\prime} 32^{\prime \prime}$ & 11.0 & 28.5 & Rapid & Intensive & A & D4 \\
\hline 39 & Mission Creek at 131st Avenue West & $46^{\circ} 40^{\prime} 13^{\prime \prime}$ & $92^{\circ} 16^{\prime} 37^{\prime \prime}$ & 10.6 & 27.5 & Rapid & Rapid full & L1 & В3с \\
\hline 40 & Mission Creek at Helburg Road & $46^{\circ} 42^{\prime} 11^{\prime \prime}$ & $92^{\circ} 20^{\prime} 02^{\prime \prime}$ & 1.20 & 3.11 & Rapid & Intensive & W.3 & E6 \\
\hline 41 & Kingsbury Creek south of Alice Street and 1st Avenue North & $46^{\circ} 44^{\prime} 13^{\prime \prime}$ & $92^{\circ} 13^{\prime} 12^{\prime \prime}$ & 7.47 & 19.4 & Rapid & Rapid full & M.3 & E4 \\
\hline 42 & Keene Creek at Bristol Street & $46^{\circ} 44^{\prime} 15^{\prime \prime}$ & $92^{\circ} 10^{\prime} 35^{\prime \prime}$ & 5.20 & 13.5 & Rapid & Rapid full & L2 & СЗb \\
\hline 43 & Chester Creek at Triggs Road & $46^{\circ} 49^{\prime} 12^{\prime \prime}$ & $92^{\circ} 06^{\prime} 40^{\prime \prime}$ & 2.79 & 7.23 & Intensive & Intensive & M.3 & E4 \\
\hline 44 & Miller Creek at Lake Superior College & $46^{\circ} 47^{\prime} 06^{\prime \prime}$ & $92^{\circ} 08^{\prime} 52^{\prime \prime}$ & 8.82 & 22.8 & Intensive & Intensive & $\mathrm{B}$ & G4 \\
\hline 45 & U.S. Steel Creek upstream from Highway 23 & $46^{\circ} 40^{\prime} 31^{\prime \prime}$ & $92^{\circ} 13^{\prime} 41^{\prime \prime}$ & 1.16 & 3.00 & $\mathrm{n} / \mathrm{a}$ & Intensive & M1 & E4 \\
\hline 46 & Coffee Creek at West 10th Street & $46^{\circ} 46^{\prime} 20^{\prime \prime}$ & $92^{\circ} 08^{\prime} 04^{\prime \prime}$ & 0.88 & 2.28 & $\mathrm{n} / \mathrm{a}$ & Rapid limited & $\mathrm{BT}$ & A2 \\
\hline 47 & Merritt Creek tributary at Skyline Drive & $46^{\circ} 45^{\prime} 45^{\prime \prime}$ & $92^{\circ} 09^{\prime} 38^{\prime \prime}$ & 1.13 & 2.93 & $\mathrm{n} / \mathrm{a}$ & Rapid full & $\mathrm{BT}$ & B2 \\
\hline 48 & Merritt Creek at Skyline Drive & $46^{\circ} 45^{\prime} 35^{\prime \prime}$ & $92^{\circ} 09^{\prime} 54^{\prime \prime}$ & 0.47 & 1.22 & $\mathrm{n} / \mathrm{a}$ & Rapid limited & $\mathrm{BT}$ & A2 \\
\hline 49 & Kingsbuy Creek downstream from Interstate 35 & $46^{\circ} 43^{\prime} 49^{\prime \prime}$ & $92^{\circ} 12^{\prime} 01^{\prime \prime}$ & 8.41 & 21.8 & $\mathrm{n} / \mathrm{a}$ & Intensive & B & B4a \\
\hline 51 & Keene Creek between Grand Avenue and 59th Avenue West & $46^{\circ} 43^{\prime} 59^{\prime \prime}$ & $92^{\circ} 10^{\prime} 20^{\prime \prime}$ & 5.52 & 14.3 & $\mathrm{n} / \mathrm{a}$ & Intensive & A & $\mathrm{C} 4$ \\
\hline 52 & Keene Creek upstream from Highland Avenue & $46^{\circ} 44^{\prime} 59^{\prime \prime}$ & $92^{\circ} 11^{\prime} 07^{\prime \prime}$ & 4.54 & 11.8 & $\mathrm{n} / \mathrm{a}$ & Intensive & $\mathrm{B}$ & A2 \\
\hline 53 & Coffee Creek upstream from Arlington Road & $46^{\circ} 47^{\prime} 07^{\prime \prime}$ & $92^{\circ} 08^{\prime} 14^{\prime \prime}$ & 0.45 & 1.17 & $\mathrm{n} / \mathrm{a}$ & Intensive & LT & $\mathrm{B} 4 \mathrm{c}$ \\
\hline
\end{tabular}

${ }^{1}$ Site 12, Amity Creek at Occidental Road Number 1, was a rapid reach in 2003 but not sampled in 2013 because it was immediately adjacent to site 13. Site 50, Kingsbury Creek upstream from Ugstad Road, was a new reach considered in 2013 but was dropped before sampling. 
Table 2. Geomorphic segment-scale classification for streams in the Duluth, Minnesota, area (from Fitzpatrick and others, 2006) with summaries of slopes, geologic settings, valley types, channel types, dominant geomorphic processes in 2003, geomorphic responses to the June 2012 flood, and Rosgen stream types.

[Reaches with intensive and rapid-full assessments have quantitative data. Remaining reaches with rapid-limited assessments have visual observations and photographs. Figure 5 contains a map of segment categories. Figure 9 has explanation of Rosgen stream types. Definition of geologic setting column: SD, supraglacial drift; SH, paleolake shoreline; BED, bedrock surface; TP, till plain; LA, glacial lake plain. Definition of valley type column: N, no valley development; E, entrenched; C, confined; A, alluvial. Definition of channel type column: WE, wetland; PR, pool-riffle; SP, step-pool; PB, plane-bed; BE, bedrock; CA, cascade; CO, colluvial; AR, artificial. >, greater than]

\begin{tabular}{|c|c|c|c|c|c|c|c|c|c|c|}
\hline $\begin{array}{l}\text { Duluth segment- } \\
\text { scale } \\
\text { classification } \\
\text { category } \\
\text { (fig. 5) }\end{array}$ & $\begin{array}{c}\text { Slope } \\
\text { (percent) }\end{array}$ & $\begin{array}{l}\text { Geologic } \\
\text { setting }\end{array}$ & $\begin{array}{l}\text { Valley } \\
\text { type } \\
\text { (fig. 6) }\end{array}$ & $\begin{array}{l}\text { Channel } \\
\text { type }\end{array}$ & $\begin{array}{l}\text { Dominant geomorphic } \\
\text { processes in } 2003\end{array}$ & $\begin{array}{l}\text { Geomorphic responses to } \\
2012 \text { flood }\end{array}$ & $\begin{array}{l}\text { Large wood } \\
\text { and pool } \\
\text { changes after } \\
2012 \text { flood }\end{array}$ & $\begin{array}{l}\text { Rosgen } \\
\text { Level II } \\
\text { stream } \\
\text { type in } \\
2013 \\
\text { (fig. 9) }\end{array}$ & $\begin{array}{l}\text { Number } \\
\text { of } \\
\text { segments }\end{array}$ & $\begin{array}{c}\text { Number of } \\
\text { reaches } \\
\text { measured in } 2013 \\
\text { (intensive+ } \\
\text { [rapid-full]) }\end{array}$ \\
\hline $\mathrm{W}$ & $<0.3$ & SD & $\mathrm{N}$ & WE & $\begin{array}{l}\text { Incision during floods, } \\
\text { aggradation during low } \\
\text { flow, runoff source }\end{array}$ & Relatively unchanged & $\begin{array}{l}\text { Potentially less } \\
\text { large wood }\end{array}$ & $\mathrm{C}, \mathrm{E}$ & 7 & $5(2)$ \\
\hline W.3 & $0.3-1$ & SD & $\mathrm{N}$ & WE & $\begin{array}{l}\text { Incision during floods, } \\
\text { aggradation during low } \\
\text { flow, runoff source }\end{array}$ & Relatively unchanged & Unknown & $\mathrm{C}, \mathrm{E}$ & 19 & $4(2)$ \\
\hline M.3 & $0.3-1$ & $\mathrm{SD} / \mathrm{SH}$ & $\mathrm{N} / \mathrm{E}$ & PR & $\begin{array}{l}\text { Bank/bluff erosion, lateral } \\
\text { migration, bar formation, } \\
\text { overbank sedimentation }\end{array}$ & $\begin{array}{l}\text { Bank/bluff erosion, widen- } \\
\text { ing, aggradation, exposed } \\
\text { bar formation, increase in } \\
\text { gravel substrate }\end{array}$ & $\begin{array}{l}\text { Less large wood, } \\
\text { fewer pools }\end{array}$ & C, F & 7 & $5(5)$ \\
\hline M1 & $>1-2$ & $\begin{array}{l}\mathrm{BED} / \mathrm{SH} \\
\text { transition }\end{array}$ & $\mathrm{C} / \mathrm{E} / \mathrm{N}$ & $\mathrm{PR} / \mathrm{SP}$ & $\begin{array}{l}\text { Bank/bluff erosion, lateral } \\
\text { migration, bar formation, } \\
\text { overbank sedimentation }\end{array}$ & $\begin{array}{l}\text { Bank/bluff erosion, widen- } \\
\text { ing, aggradation, exposed } \\
\text { bar formation, increase in } \\
\text { gravel substrate }\end{array}$ & $\begin{array}{l}\text { Less large wood, } \\
\text { fewer pools }\end{array}$ & $\mathrm{B}, \mathrm{C}, \mathrm{E}, \mathrm{F}$ & 19 & $7(6)$ \\
\hline M2 & $>2-4$ & $\mathrm{BED} / \mathrm{SH}$ & $\mathrm{C}$ & $\mathrm{SP} / \mathrm{PB}$ & $\begin{array}{l}\text { Bank/bluff erosion, lateral } \\
\text { migration, bar formation }\end{array}$ & $\begin{array}{l}\text { Bank/bluff erosion, widening, } \\
\text { aggradation }\end{array}$ & Unknown & $\mathrm{B}, \mathrm{E}$ & 6 & $1(1)$ \\
\hline B & $>4$ & BED & $\mathrm{C} / \mathrm{E}$ & $\mathrm{BE} / \mathrm{CA}$ & $\begin{array}{l}\text { Channel expansion, bluff } \\
\text { erosion }\end{array}$ & $\begin{array}{l}\text { Incision, exposed bar forma- } \\
\text { tion, variable bank/bluff } \\
\text { erosion, increase in gravel } \\
\text { substrate }\end{array}$ & $\begin{array}{l}\text { Unknown wood, } \\
\text { number of } \\
\text { pools remain } \\
\text { relatively high }\end{array}$ & A, B, G & 30 & $11(9)$ \\
\hline $\mathrm{BT}$ & $>4$ & BED & $\mathrm{C}$ & $\mathrm{CO} / \mathrm{CA}$ & $\begin{array}{l}\text { Channel expansion, incision, } \\
\text { gully erosion }\end{array}$ & Unknown & Unknown & A, B & 19 & $5(3)$ \\
\hline L2 & $>2-4$ & $\begin{array}{l}\mathrm{BED} / \mathrm{TP} \\
\text { transition }\end{array}$ & $\mathrm{C} / \mathrm{E}$ & $\mathrm{PB} / \mathrm{BE}$ & $\begin{array}{l}\text { Channel expansion, widen- } \\
\text { ing, bank erosion, bar } \\
\text { formation }\end{array}$ & $\begin{array}{l}\text { Mostly aggradation but some } \\
\text { localized incision, bank/ } \\
\text { bluff erosion, increase in } \\
\text { gravel substrate }\end{array}$ & $\begin{array}{l}\text { Less large wood, } \\
\text { fewer pools }\end{array}$ & $\mathrm{B}, \mathrm{F}$ & 10 & $3(2)$ \\
\hline
\end{tabular}


Table 2. Geomorphic segment-scale classification for streams in the Duluth, Minnesota, area (from Fitzpatrick and others, 2006) with summaries of slopes, geologic settings, valley types, channel types, dominant geomorphic processes in 2003, geomorphic responses to the 2012 flood, and Rosgen stream types. - Continued

[Reaches with intensive and rapid-full assessments have quantitative data. Remaining reaches with rapid-limited assessments have visual observations and photographs. Figure 5 contains a map of segment categories. Figure 9 has explanation of Rosgen stream types. Definition of geologic setting column: SD, supraglacial drift; SH, paleolake shoreline; BED, bedrock surface; TP, till plain; LA, glacial lake plain. Definition of valley type column: N, no valley development; E, entrenched; C, confined; A, alluvial. Definition of channel type column: WE, wetland; PR, pool-riffle; SP, step-pool; PB, plane-bed; BE, bedrock; CA, cascade; $\mathrm{CO}$, colluvial; AR, artificial. >, greater than]

\begin{tabular}{|c|c|c|c|c|c|c|c|c|c|c|}
\hline $\begin{array}{l}\text { Duluth segment- } \\
\text { scale } \\
\text { classification } \\
\text { category } \\
\text { (fig. 5) }\end{array}$ & $\begin{array}{c}\text { Slope } \\
\text { (percent) }\end{array}$ & $\begin{array}{l}\text { Geologic } \\
\text { setting }\end{array}$ & $\begin{array}{l}\text { Valley } \\
\text { type } \\
\text { (fig. 6) }\end{array}$ & $\begin{array}{l}\text { Channel } \\
\text { type }\end{array}$ & $\begin{array}{c}\text { Dominant geomorphic } \\
\text { processes in } 2003\end{array}$ & $\begin{array}{l}\text { Geomorphic responses to } \\
2012 \text { flood }\end{array}$ & $\begin{array}{l}\text { Large wood } \\
\text { and pool } \\
\text { changes after } \\
2012 \text { flood }\end{array}$ & $\begin{array}{l}\text { Rosgen } \\
\text { Level II } \\
\text { stream } \\
\text { type in } \\
2013 \\
\text { (fig. 9) }\end{array}$ & $\begin{array}{l}\text { Number } \\
\text { of } \\
\text { segments }\end{array}$ & $\begin{array}{c}\text { Number of } \\
\text { reaches } \\
\text { measured in } 2013 \\
\text { (intensive+ } \\
\text { [rapid-full]) }\end{array}$ \\
\hline L1 & $>1-2$ & TP/LA & $\mathrm{C} / \mathrm{E}$ & $\mathrm{PB}$ & $\begin{array}{l}\text { Channel expansion, widen- } \\
\text { ing }\end{array}$ & $\begin{array}{l}\text { Channel expansion, widening, } \\
\text { variable bar bank/bluff ero- } \\
\text { sion, variable bar formation }\end{array}$ & Unknown & $\mathrm{B}, \mathrm{C}$ & 6 & $7(3)$ \\
\hline LT & $>2-4$ & $\begin{array}{l}\mathrm{SD} / \mathrm{BED} / \\
\mathrm{SH}\end{array}$ & $\mathrm{C}$ & $\begin{array}{l}\mathrm{PB} / \mathrm{CO} / \\
\mathrm{BE}\end{array}$ & $\begin{array}{l}\text { Incision, gully erosion, bank } \\
\text { erosion, lateral migration }\end{array}$ & Unknown & Unknown & B & 11 & $1(1)$ \\
\hline A & $0.3-1$ & TP/LA & $\mathrm{A} / \mathrm{N}$ & PR/AR & Aggradation & $\begin{array}{l}\text { Aggradation, bank/bluff } \\
\text { erosion, widening, bar } \\
\text { formation }\end{array}$ & Unknown & $\begin{array}{l}\text { A, B, C, } \\
\text { D }\end{array}$ & 9 & $3(2)$ \\
\hline U1 & $>1-2$ & SD & $\mathrm{N}$ & PR? & Incision, bank erosion & Unknown & Unknown & Unknown & 4 & $0(0)$ \\
\hline $\mathrm{U} 2$ & $>2-4$ & $\begin{array}{l}\mathrm{SD} / \mathrm{BED} / \\
\mathrm{SH}\end{array}$ & $\mathrm{C}$ & $\mathrm{PB} / \mathrm{SP} ?$ & Incision, bank/bluff erosion & Unknown & Unknown & Unknown & 7 & $0(0)$ \\
\hline $\mathrm{T} 1$ & $>1-2$ & $\begin{array}{l}\mathrm{SD} / \mathrm{BED} \\
\text { transition }\end{array}$ & $\mathrm{E} / \mathrm{C} / \mathrm{N}$ & PR? & $\begin{array}{l}\text { Incision, widening, bank } \\
\text { erosion, gully erosion }\end{array}$ & Unknown & Unknown & Unknown & 12 & $0(0)$ \\
\hline $\mathrm{T} 2$ & $>2-4$ & $\mathrm{BED} / \mathrm{SH}$ & $\mathrm{C} / \mathrm{E}$ & $\mathrm{PB} ?$ & $\begin{array}{l}\text { Incision, gully erosion, bank } \\
\text { erosion }\end{array}$ & Unknown & Unknown & Unknown & 21 & $0(0)$ \\
\hline
\end{tabular}



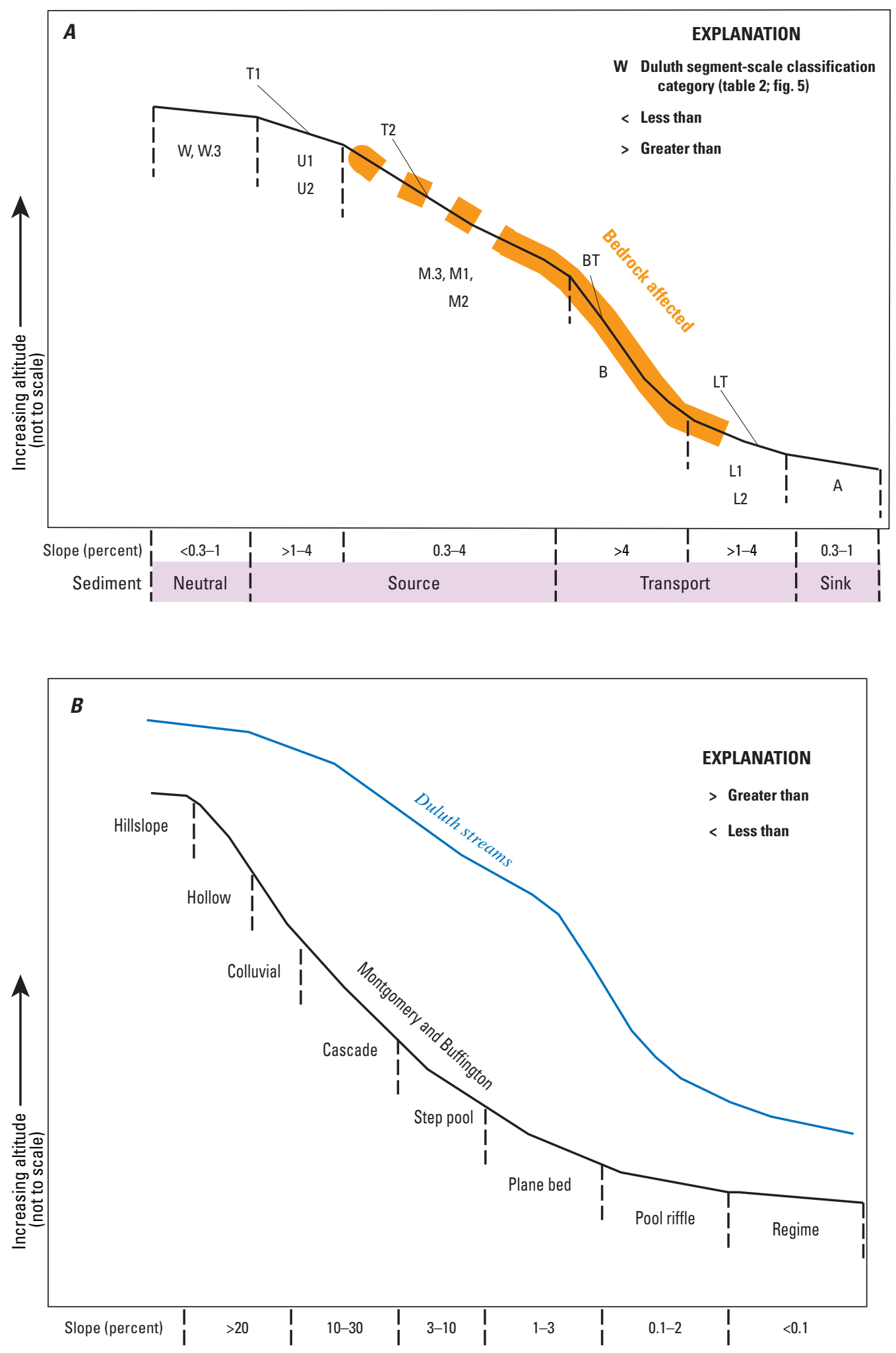

Figure 4. Typical convex-up longitudinal profiles of altitude changes of Duluth-area streams from headwaters to rivermouths at Lake Superior with overlays. $A$, Duluth segment-scale classification (Fitzpatrick and others, 2006). B, Montgomery-Buffington channel bedform types (Montgomery and Buffington, 1998). C, Rosgen Level II stream types (Rosgen, 1994). 


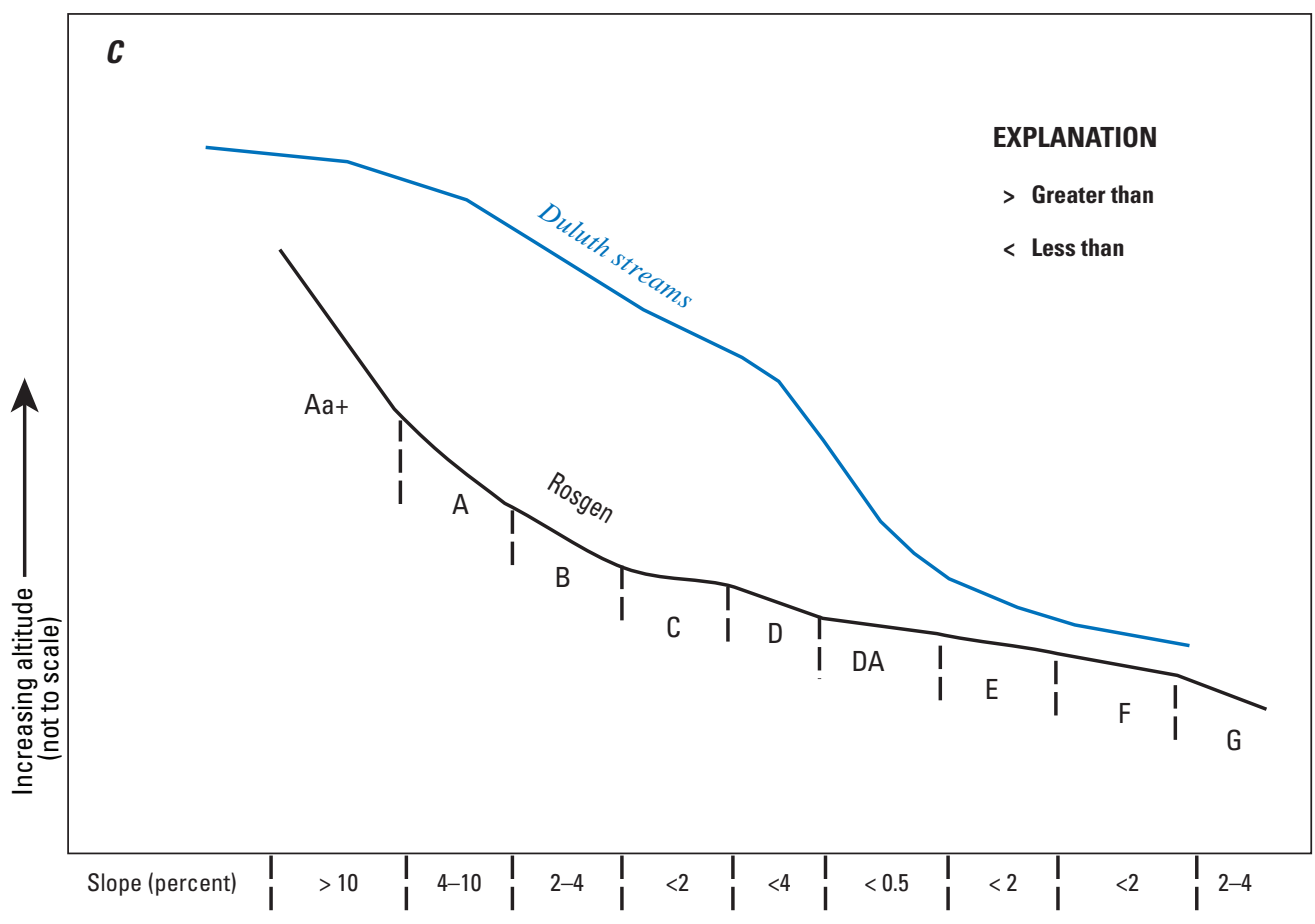

Figure 4. Typical convex-up longitudinal profiles of altitude changes of Duluth-area streams from headwaters to rivermouths at Lake Superior with overlays. $A$, Duluth segment-scale classification (Fitzpatrick and others, 2006). B, MontgomeryBuffington channel bedform types (Montgomery and Buffington, 1998). C, Rosgen Level II stream types (Rosgen, 1994).-Continued shrub, and lowland forest cover types are present in wetland settings.

\section{Methods for Stream Geomorphic and Habitat Data Collection}

The 2013 postflood assessment built off of the 2003-4 geomorphic study in two main aspects. First, newly available digital elevation model (DEM) data generated from light detection and ranging (lidar) data were used to check 2013 channel slopes against the 2003-4 channel slopes that were hand measured from streamline distances between contour lines on 1:24,000-scale USGS topographic maps. Secondly, field measurements and observations were collected from August to October 2013 at 51 sites (table 1). The field measurements combined quantitative and qualitative methods at three tiered levels of intensity: intensive, rapid-full, and rapidlimited (fig. 1). Site selection and intensity of field measurements were chosen to provide comparability with the 2003-4 results. Detailed methods are described in the following sections for the segment-scale classification; reach selection; field assessments at intensive, rapid-full, and rapid-limited sites; and calculation of Rosgen Level II stream types.

\section{Duluth Segment-Scale Characterization and Classification}

The 2003-4 Duluth geomorphic segment-scale classification, partially based on the Montgomery and Buffington (1993,
1997, 1998) channel classification, is thoroughly described in Fitzpatrick and others (2006) and is the primary segment-scale classification used for the 2013 study to determine the longitudinal continuum of geomorphic responses related to the 2012 flood (table 2; fig. 5). In 2003-4, Duluth-area stream segments were hand-delineated in a geographic information system (GIS) with a base of topographic contour lines and stream blue lines from 1:24,000-scale USGS topographic maps (Fitzpatrick and others, 2006).

In 2013, a slope check was done for the study sites based on lidar data (National Oceanic and Atmospheric Administration, 2008) collected in 2012 for Minnesota (Minnesota Department of Natural Resources, 2015) overlain with 2013 aerial photography (St. Louis County Minnesota, 2014). The lidar-based slopes sometimes varied from the estimated slopes for 2003-4 reconnaissance and drive-by sites. After the slope check using lidar data, as well as checks of presence of bedrock and any differences in reach locations between 2003-4 and 2013 assessments, the Duluth segment-scale classification categories for the 2013 sites were updated if needed. Data for each reach comparing 2003-4 and 2013 segment categories are in appendix 1.

\section{Stream Site Selection}

In 2003-4, field-based geomorphic assessments were completed at 48 sites in 20 stream basins in the Duluth area. The sites were chosen to verify the map-based segment-scale categorization and further describe channel morphologic and sediment characteristics. Intensive assessments were done at 9 of the 48 sites representing the most common segment 


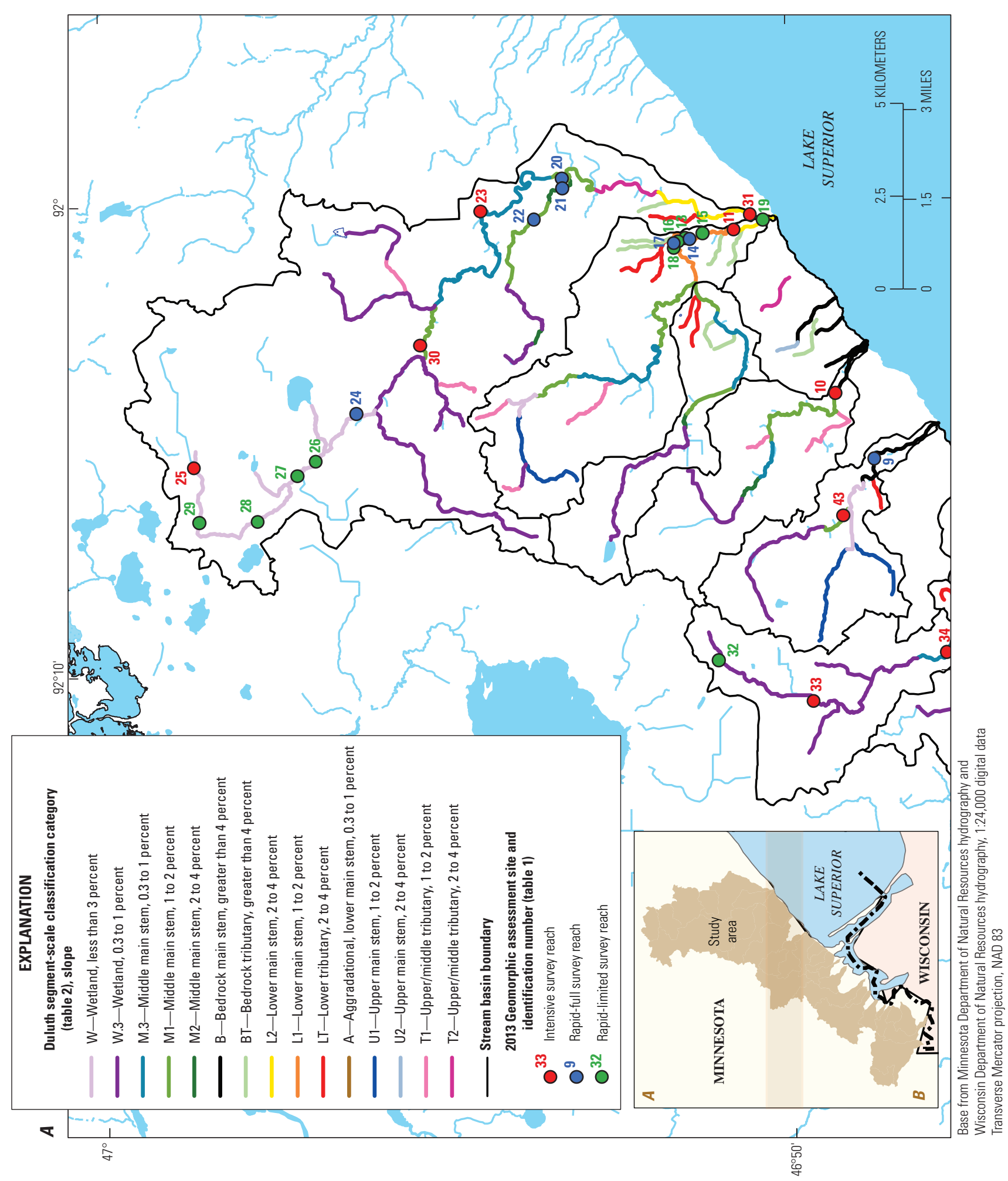

Figure 5. Geomorphic segment classification for Duluth-area streams, Minnesota (Fitzpatrick and others, 2006), overlain with 2013 geomorphic assessment sites. $A$, northern area. $B$, southern area. 


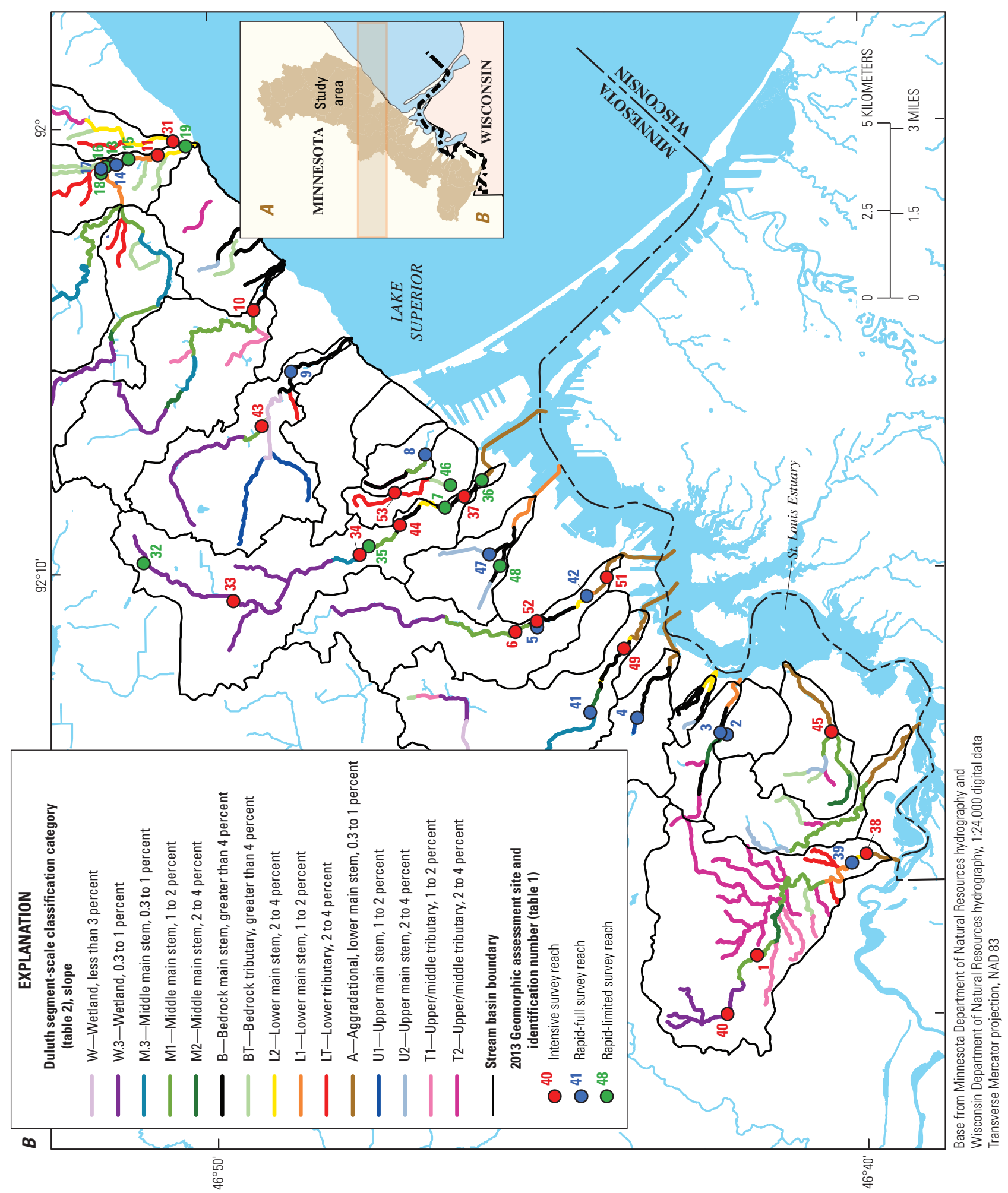

Figure 5. Geomorphic segment classification for Duluth-area streams, Minnesota (Fitzpatrick and others, 2006), overlain with 2013 geomorphic assessment sites. $A$, northern area. $B$, southern area.-Continued 

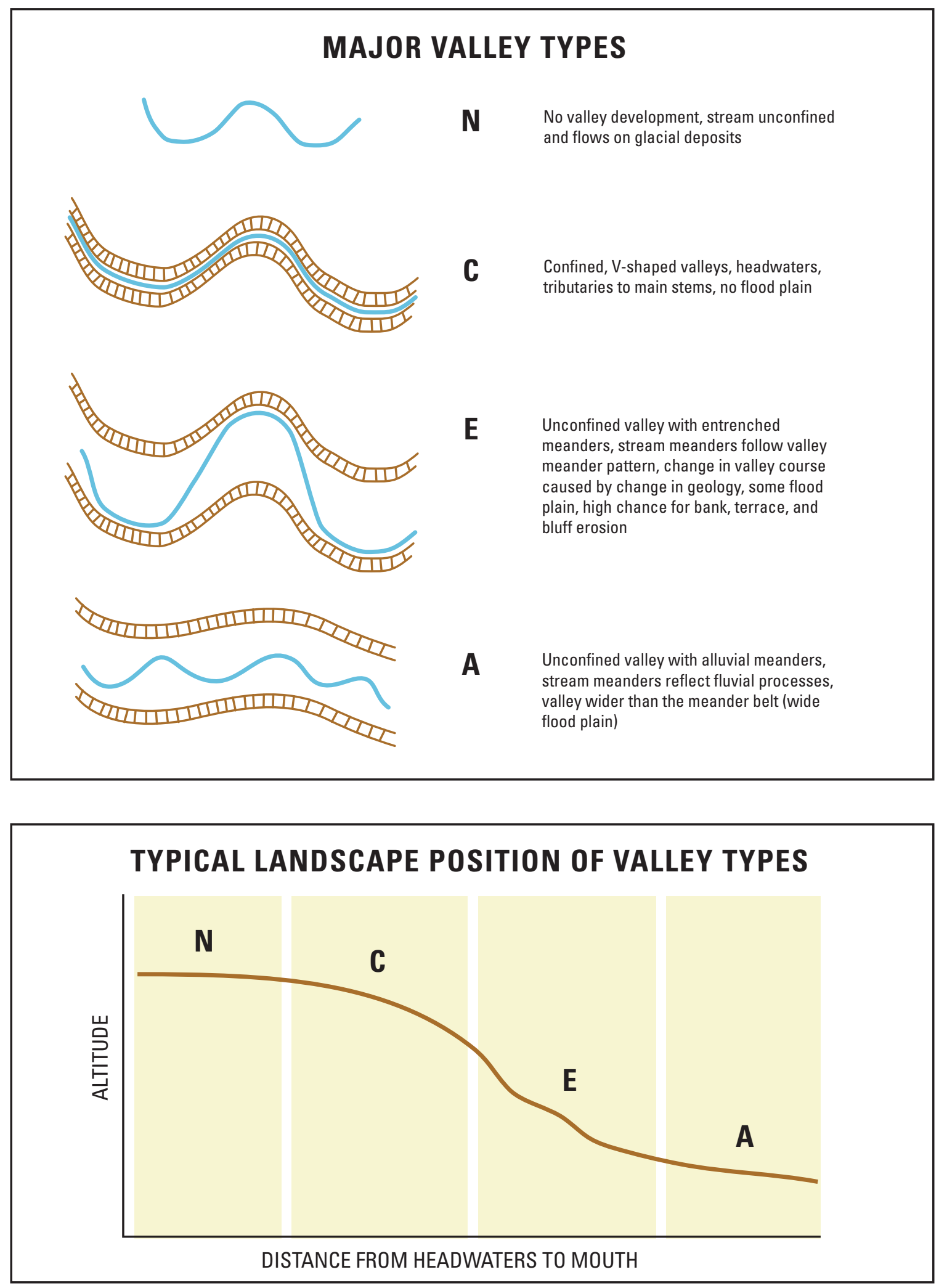

Figure 6. Valley development and valley types along a longitudinal continuum (from Fitzpatrick and others, 2006). 
$92^{\circ}$



Figure 7. Bedrock geology of the Duluth, Minnesota, area (from Miller and others, 2001). 


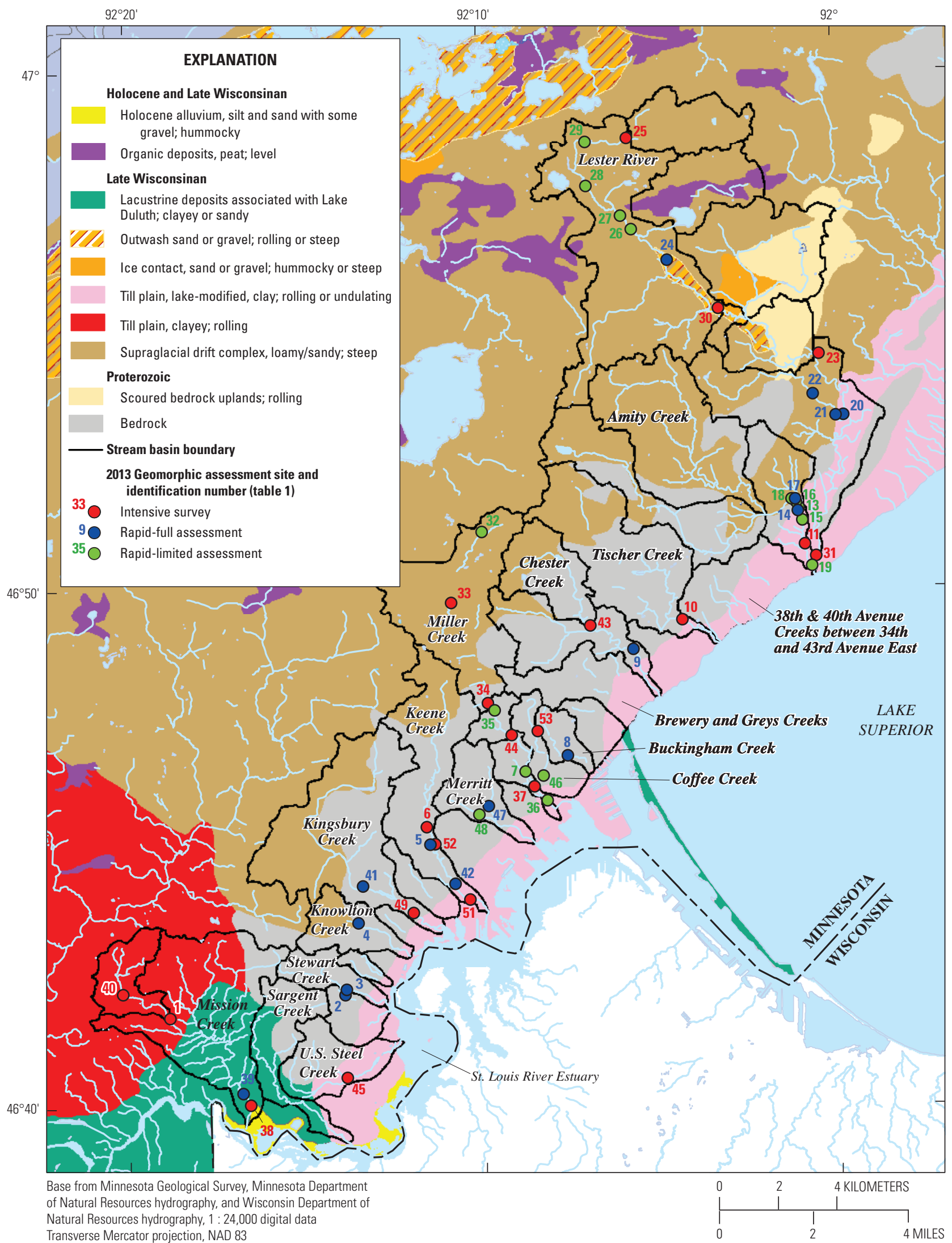

Figure 8. Surficial geology and geomorphology of the Duluth, Minnesota, area. 
types. In addition, multiple sites were assessed in the Mission Creek, Keene Creek, Miller Creek, and Lester River Basins to describe how geomorphic characteristics and processes changed along the longitudinal profiles.

In 2013, field-based assessments were completed at the 48 sites of 2003-4, and at 3 new sites (fig. 1; table 1). In addition to expanding the number of sites with intensive assessments from 9 in 2003-4 to 20 in 2013, two types of rapid assessments were completed at the remaining 2013 sites at what were reconnaissance or drive-by sites in 2003-4. Out of the 202013 intensive sites, 8 had repeat surveys at 2003-4 intensive sites, and 12 additional intensive sites were either rapid assessment sites in 2003-4 or were new sites that had notable geomorphic change during the 2012 flood. Detailed maps showing the locations of the intensive assessment sites in 2003-4 and 2013 are in appendix 2. Rapid-full assessments included a subset of quantitative data collected at the intensive sites. Rapid-limited assessments included photographs and qualitative field observations.

\section{Intensive Field Assessments}

Intensive field assessments involved collecting qualitative and quantitative data that were chosen to match measurements used in previous geomorphic assessment studies, such as the 2003-4 Duluth geomorphic assessment (Fitzpatrick and others, 2006; Thorne, 1998), modified habitat assessments used for the National Water-Quality Assessment Program (Fitzpatrick and others, 1998), and bankfull regional curve studies (for example, Cinotto, 2003; Rosgen, 1996, 2009). Reach length was determined to be $150 \mathrm{~m}$. Descriptive categories for general reach conditions included flood plain and valley setting, overbank deposits, bed and width controls, channel types, and stream type (perennial, intermittent, or ephemeral). Channel types were identified as colluvial, bedrock, cascade, step-pool, pool-riffle, artificial, plane-bed, or wetland (modified from Montgomery and Buffington, 1998; Fitzpatrick and others, 2006). A diagrammatic map was drawn that included notable features, such as bends, downed trees, eroding banks, and transect locations (Fitzpatrick and others, 1998). Identifying bankfull depth and measuring bankfull channel widths can be difficult in urban streams (Rosgen, 1985, 1996; Bent and Waite, 2013), not to mention the extra difficulty of having recently eroded channels after the 2012 flood. Following Fitzpatrick and others (1998), bankfull channel dimensions were exclusively based on physical indicators of channel morphology.

The reach was divided into 21 equidistant transects spaced $7.5 \mathrm{~m}$ apart with additional measurements at every other transect. Bankfull and wetted width, bankfull depth, and entrenchment ratio (Rosgen, 1994, 1996) were measured, and the geomorphic channel unit (riffle, glide, pool, rapids, or falls) was recorded at each transect. The entrenchment ratio was calculated from methods consistent with Rosgen (1994, 1996) and is the ratio of the flood-prone width to the bankfull width. The flood-prone width is measured at a height of twice the maximum depth of the bankfull channel along a transect. Bank-related measurements of water depth, total bank height, bank angle, categorical bank condition, bank vegetation type and amount of cover, and dominant substrate were collected at each transect endpoint and summarized into a bank stability index (Simon and Hupp, 1992; Fitzpatrick and others, 1998). Photographs upstream, downstream, and of left and right banks were taken at each transect.

In addition to measurements at transects, the length and area of eroding banks and exposed bars were measured between transects. Locations were noted with a hand-held global positioning system device and relative position to transect numbers. The length, height, and extent of undercut banks were recorded, along with the predominant mechanism forcing erosion at each. Similarly, the location, position in the channel, length, width, dominant substrate, and vegetation type were recorded for exposed bars and islands.

Any evidence of artificial channel alterations was noted; the length of alterations along the channel was measured; and bank stabilization, habitat improvements, and grade control structures also were noted. The length of channelization and fencing along both banks was recorded as a percent of the reach length. The presence of lunker structures, cattle crossings, log cross vanes, constructed riffles, rock vanes, habitat cover, coir logs, erosion blankets, rootwads, sheet pile, gabions, live stakes, riprap or river rock, concrete, or bank shaping was recorded. Distance upstream and downstream to nearest grade control, along with the head drop and type, were noted. An important part of the assessment was to look for visual indicators of major geomorphic processes, including evidence of headcutting, incision, bluff erosion, bank erosion, widening, lateral migration, overbank sedimentation, bar formation, aggradation, and expansion of the flow area at bedrock sites. Similar to Thorne (1998) techniques, the visual indicators were qualified with a degree of confidence in the observation as discerned by the observer.

\section{Channel Cross Sections and Longitudinal Profiles}

Channel topographic cross sections and longitudinal profiles were surveyed using an electronic total station, optical level and tape, or real-time network (RTN) survey-grade global navigation satellite system (GNSS) (Henning, 2011; Rydlund and Densmore, 2012). Existing benchmarks from the 2003-4 surveys were located and used in the 2013 surveys. All surveys had centimeter or subcentimeter precision. The RTNGNSS was the primary means of surveying. At sites where the RTN-GNSS was unable to get sufficient satellite coverage because of overhead vegetation or obstructions, the electronic total station or optical level was used with relative horizontal and vertical coordinates. For about one-half of the intensive sites surveyed in relative coordinates, one or two placed rebar benchmarks were surveyed with RTN-GNSS, allowing translation from arbitrary $\mathrm{x}, \mathrm{y}$, and $\mathrm{z}$ coordinates into absolute coordinates. For surveys without RTN-GNSS, arbitrary 
coordinates in the survey data were converted to approximate georeferenced altitudes by overlaying transect points located with handheld GNSS readings with aerial photography and the 2012 lidar in a GIS. The estimated altitudes were selected based on lidar-based altitudes of the overbank survey points, such as top of bank or terrace points. The data for reach surveys and associated benchmarks are in appendix 3. Altitudes for survey data and lidar are referenced to the North American Vertical Datum of 1988.

Three to seven channel cross sections were surveyed at each intensive site. These cross sections characterized typical riffles, runs, and pools. Semipermanent benchmarks (rebar stakes) were established at each cross section. Topographic survey points included terrace and flood-plain surfaces (if necessary), tops of banks, bankfull indicators, bank slopes, channel toe, channel bed and thalweg, or any other major change in slope along the transect.

In addition to surveyed topographic cross sections, longitudinal profiles also were surveyed. Water-surface and channel thalweg points were surveyed along the reach; points were taken at intervals of one channel width, as well as at all local slope breaks. These long profiles were used to compute water surface and streambed slopes from riffle to riffle and for the reach.

\section{In-Channel Substrate}

Sediment characteristics were quantified along sites using three techniques: (1) using modified Wolman pebble counts (Wolman, 1954; Young and others, 2015), (2) mapping of areas of silt deposition, and (3) mapping of coarse-grained exposed bars. Wolman pebble counts were completed by selecting 5 equidistant points across the channel at each of the 21 transects yielding 105 total points per reach. At each point, a meter stick or rod held vertically along a tape strung perpendicular to the channel was used to determine a point on the channel bed. At this point, the water depth and soft sediment thickness (if present) was measured with the meter stick; and particle size for the soft and hard substrate was recorded. If the particle size was gravel or larger, a gravelometer was used. A sand card was used to visually determine sand-size categories. Other categories included silt, clay, and organic detritus. Also noted at each point was the presence of riprap, macrophytes, silt coatings, or wood.

The 2013 pebble count method was different than that used during the 2003-4 assessments in two ways. The b-axis of about 100 or more pebbles was measured with a ruler instead of a gravelometer. Additionally, the step-and-point method was used at a representative surveyed cross section in a riffle instead of the entire reach (Fitzpatrick and others, 2006; Rosgen and others, 2008). For comparing substrates in sites with overlapping 2003-4 and 2013 pebble count data, cumulative frequency plots were constructed with a subset of 2013 transects that overlapped the riffle sampled in 2003-4.

Exposed bars and islands were described by type (marginal, midchannel, point bar, or island) and measured for exposed length and width. Dominant substrate and vegetation cover (bar, herbaceous, or woody) were recorded.

The volume and areal extent of soft sediment deposits were measured for any deposit larger than 30 square centimeters $\left(\mathrm{cm}^{2}\right)$. Soft sediment deposits are defined as those unable to support the weight of a human while wading and usually consisted of fine-grained silts and clays with high water content. The type was described; length, width, and thickness were measured; and vegetation cover was described for each soft sediment deposit.

\section{Large Wood}

Wood that is embedded, lodged, or both in the main-stem channel, near the edges of the channel, or partially obstructing the channel exerts a positive effect on aquatic ecology and can force striking changes to the morphology of the stream (Beschta, 1979; Montgomery and others, 1995). Embedded wood dissipates energy by creating bed features, such as step-pools and cascades in steeper sites, to reduce sediment transport, helping to balance the transport capacity/sediment supply ratio (Heede, 1972; Smith and others, 1993; Gurnell and others, 1995).

The number, length, and average diameter of large wood pieces were measured in each reach using methods similar to the 2003-4 assessment (Fitzpatrick and others, 2006). Geomorphic function and source for the wood were recorded. Possible functions included pool scour, bank stability, bar stabilizer, sediment trap, or step former. Possible sources for the wood included side slope, upstream, or bank. All wood within the bankfull channel was measured that was larger than $3 \mathrm{~cm}$ in diameter and $0.3 \mathrm{~m}$ in length. The small minimum size of wood counted in this study was selected to maximize options for comparing wood counts in Duluth-area streams with wood surveys completed by others.

\section{Pools}

Pools are important morphological features that affect stream morphology by dissipating stream energy and enhance the ecosystem by providing critical habitat for fish and other aquatic organisms. Pools form from localized convergent flow within the channel or may be created by local obstructions (bedrock, boulders, bank projections, and large wood) that cause scour to the channel bed (Keller and Swanson, 1979; Beschta, 1983; Lisle, 1986). Pools vary in shape and size according to obstruction characteristics, such as size, amount of channel constriction, vertical displacement in relation to bankfull depth, and horizontal angle of deflection (Beschta, 1983; Sullivan and others, 1987; Lisle, 1986). Where logs or boulders form dams across the channel, deep, short plunge pools are formed; and when obstructions only partly span the channel, scoured pools tend to be longer and shallower (Sullivan and others, 1987). Pools are also at meander bends and across the channel from point bars. Pool features can 
be lost if streams respond to disturbances by changing from being relatively deep and narrow to being shallower and wider (Beschta and Platts, 1986). Large inputs of coarse sediments from streambank failure and mass wasting also can effectively remove channel depressions by filling pools (Sullivan and others, 1987).

Pools provide important habitat for fish populations during average flows and are critical fish-rearing habitat during low flows when much of the stream's water volume resides in pool recessions in the stream channel (Beshta and Platts, 1986). Deep, slow-velocity pools with overhanging cover are associated with the highest and most stable fish populations (Saunders and Smith, 1962).

The area and maximum depth of pools were measured in 2013, similar to the 2003-4 assessment. Pools were identified by having relatively deep, slow-moving water and fine-grained bed material compared to the rest of the reach. Types of pool forcing were recorded and included free, woody debris, or bedrock/boulder/bank. Average pool-to-pool spacing was calculated by dividing the reach length by the number of pools.

\section{Rapid Field Assessments}

Rapid field assessments of geomorphic characteristics and processes were completed at 31 sites from August through October 2013 (fig. 1). Rapid assessments completed in 2013 were designated as either rapid-full (subset of quantitative data collected at intensive sites) or rapid-limited (mainly photo comparison and observational notes). The additional measurements collected at rapid-full sites in 2013 helped to expand the spatial extent and variability measured at the intensive sites.

\section{Rapid-Full Assessments}

Geomorphic and habitat data were collected at 16 rapidfull assessment sites, which consisted of a smaller subset of data that were collected at the intensive sites. Reach length was held at $150 \mathrm{~m}$ similar to intensive sites, but only 5 transects were measured compared to the 21 transects measured at intensive sites. If available, the five transects represented two riffles, two runs, and a pool. Channel morphology, bar formation, general substrate categories, controls on incision and lateral migration, and bank stability were measured and described at each of the five transects. Field indicators for delineation of bankfull channel characteristics were identified according to Fitzpatrick and others (1998). Bankfull width, bankfull depth, entrenchment ratio (Rosgen, 1985, 1994, 1996), and wetted width were measured with a tape by hand at each transect. At three equidistant points along each transect, the wetted depth, average soft sediment thickness, and dominant streambed substrate were recorded.

Other data were collected at a similar quantitative level as intensive sites, including length and height of eroding banks. Similarly, the number and length of stream habitat structures, bank stabilization, grade control, channelization, and riparian fencing were measured along both banks. Type of road crossings, potential fish-passage problems through culverts, and any other potential local effect to the stream channel were noted. Culverts are common in Duluth-area streams and, if inappropriately constructed, can be obstructions to fish migration (Gibson and others, 2005). Photographs were taken at measured transects looking upstream, looking downstream, and of both banks.

Channel slopes for the rapid-full sites were estimated in a GIS from the DEMs generated from the 2012 airborne lidar data. These DEMs were used to generate stream reach maps, which then were superimposed on the corresponding Land Pictometry 2013 aerial imagery (St. Louis County Minnesota, 2014).

\section{Rapid-Limited Assessments}

Rapid-limited assessments were completed at 15 sites from August through October 2013. These sites were included in the 2003-4 assessments as rapid sites, which consisted of repeat photographs taken from similar locations as 2003-4 photographs and visual observations of valley type, channel type, general substrate size, and bedrock type. In 2003-4, a quick slope check was done with a hand level and rod to verify that the reach slope fell within the category of segment slope that it represented. Visually determined notes on geomorphic changes and sediment transport from the 2012 flood were recorded. Similar to rapid-full sites, 2013 channel slopes were estimated from lidar data. A visual check of valley and channel types was done to verify the 2003-4 Duluth segment-scale classification category.

\section{Rosgen Stream Types}

Rosgen Level I analyses and Level II stream types (fig. 9; Rosgen, 1985, 1994, 1996) were assembled at the sites with intensive and rapid-full geomorphic assessments. Level I describes geomorphic characteristics that result from the integration of basin topographic relief, landform, and valley morphology. Level II field measurements included entrenchment ratio (ratio of flood-prone width to bankfull width), bankfull width/depth ratio, sinuosity, slope, and categorical channel bed particle size. The Rosgen Level II classification assigns an alphanumeric code that identifies a range of geometric parameters along with a specific channel material (that is, boulders, cobbles, or gravel). The classification is founded on "reference streams" that demonstrate stability (reference streams transport the supply of sediment with no substantial change in dimension, pattern, or profile [Rosgen, 1994]). Channel dimensions, planform, amount of entrenchment, and slope are used to delineate eight major stream types. Type "A" streams are steep (4-10 percent slopes) and have cascading, step-pool bed morphologies. Type "B" streams have moderate slopes ranging from 2 to 4 percent and bed morphologies dominated by rapids. Stream types of "C," "E," and "F" have 


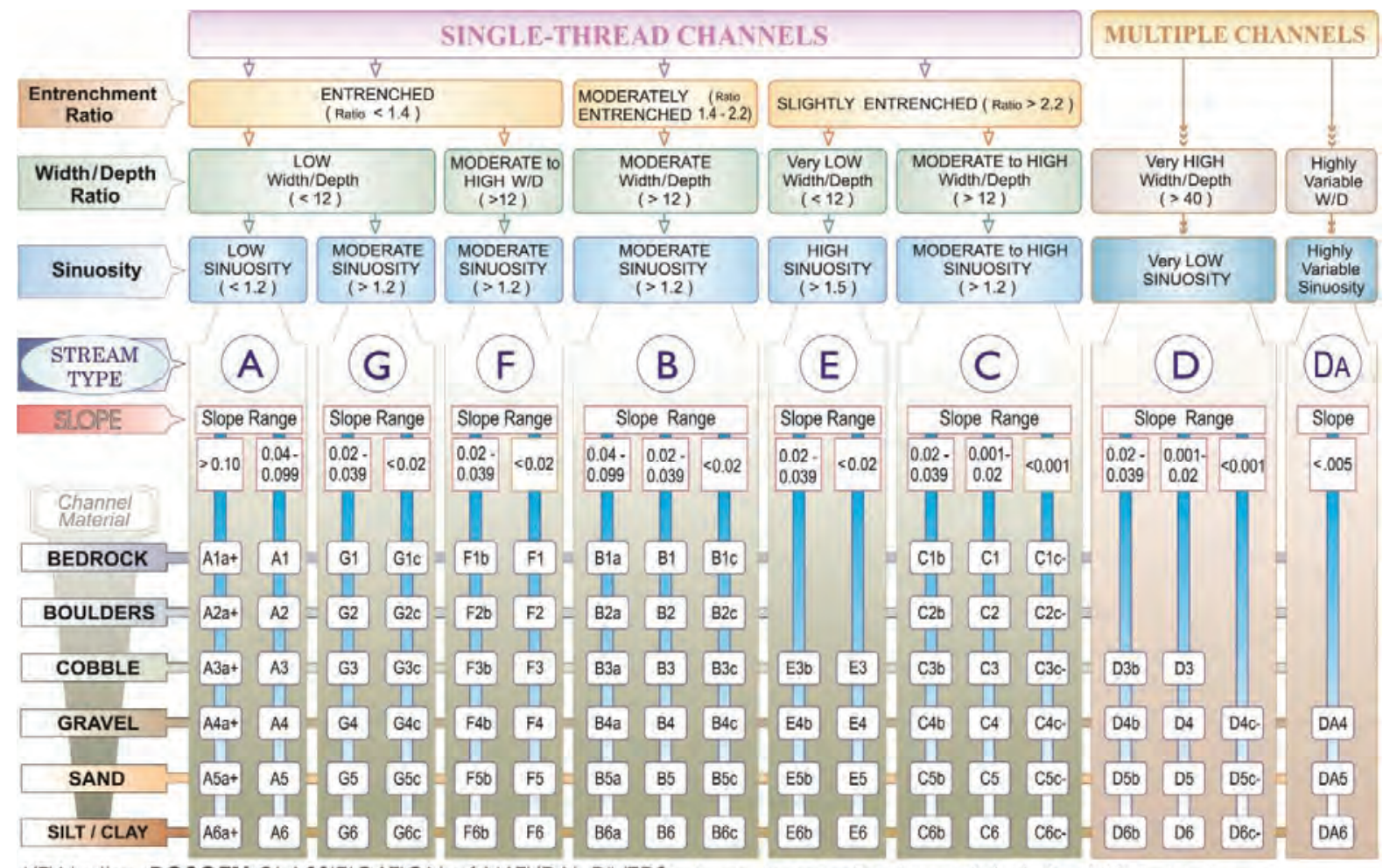

EXPLANATION

$<$ Less than

$>$ Greater than

$+/-$ Plus or minus

KEY to the ROSGEN CLASSIFICATION of NATURAL RIVERS. As a function of the "continuum of physical variables" within stream

reaches, values of Entrenchment and Sinuosity ratios can vary by $+1-0.2$ units, while values for Width / Depth ratios can vary by $+1-2.0$ units.

Figure 9. Rosgen Level II stream classification key (Rosgen 1994, 1996).

gentle slopes and riffle/pool bed morphologies. Types " $\mathrm{D}$ " and " $\mathrm{D}_{\mathrm{A}}$ " are multithread channels with gentle slopes. Type "G"

streams are steep step-pool channels or gullies (Rosgen, 1994). Level II classification provides a more detailed morphological description from quantitative field measurements, and recent geomorphic changes caused by flooding in June 2012 offered new insights into responses of specific stream types defined in the Rosgen Level II classification scheme.

Rosgen (1996) also identified specific stream types that are vulnerable to change or are in a degraded condition because of imposed natural or anthropogenic changes to streamflow or sediment supply; for example, "C" stream types are vulnerable to substantial alterations and may rapidly destabilize when the effects of imposed changes in bank stability, basin condition, or flow regime are combined to cause an imbalance between transport capacity and sediment supply. Type " $D$ " streams are associated with high bank-erosion rates, high sediment supply, and bed features that have resulted from geomorphic processes of local bed scour and sediment deposition such that aggradation and lateral extension are dominant channel adjustment processes. Even though type "E" streams are considered to be highly stable under steady boundary conditions, they are identified as very sensitive to disturbance and can be rapidly modified and converted to other stream types in a relatively short time. Type "F" streams can develop very high bank-erosion rates; develop lateral-extension rates; and have substantial bar deposition and accelerated channel aggradation, degradation, or both while providing for high sediment supply and storage capacities. Rosgen (2001) expanded the application of stream types to predict channel adjustments and stability, where morphological adjustments happen as a result of change in magnitude, frequency, and intensity of streamflow, and (or) changes in sediment supply. Large magnitude or persistent changes (or both) in hydrology or sediment supply may cause morphologic adjustments to a point where a stream's type classification changes. Some examples of a small subset of all the possible changes in Level II stream types are shown in figure 10. Comparisons of 2003-4 and 2013 stream types were possible for eight intensive sites.

\section{Stream Geomorphic Responses to the June 2012 Flood}

The longitudinal continuum approach used in the Dulutharea (fig. 1) segment-scale classification helped to explain overall patterns in dominant geomorphic responses to the 2012 flood, although some notable exceptions were observed (table 2). The 2003-4 and repeated 2013 assessments at a subset of intensive sites provided direct comparison of quantitative data on channel morphology, substrate size, large wood abundance, and pool frequency changes associated with the 2012 flood. Combined quantitative data of all the 2013 intensive sites were used for describing spatial variability in these four components, as well as additionally the amount of exposed 


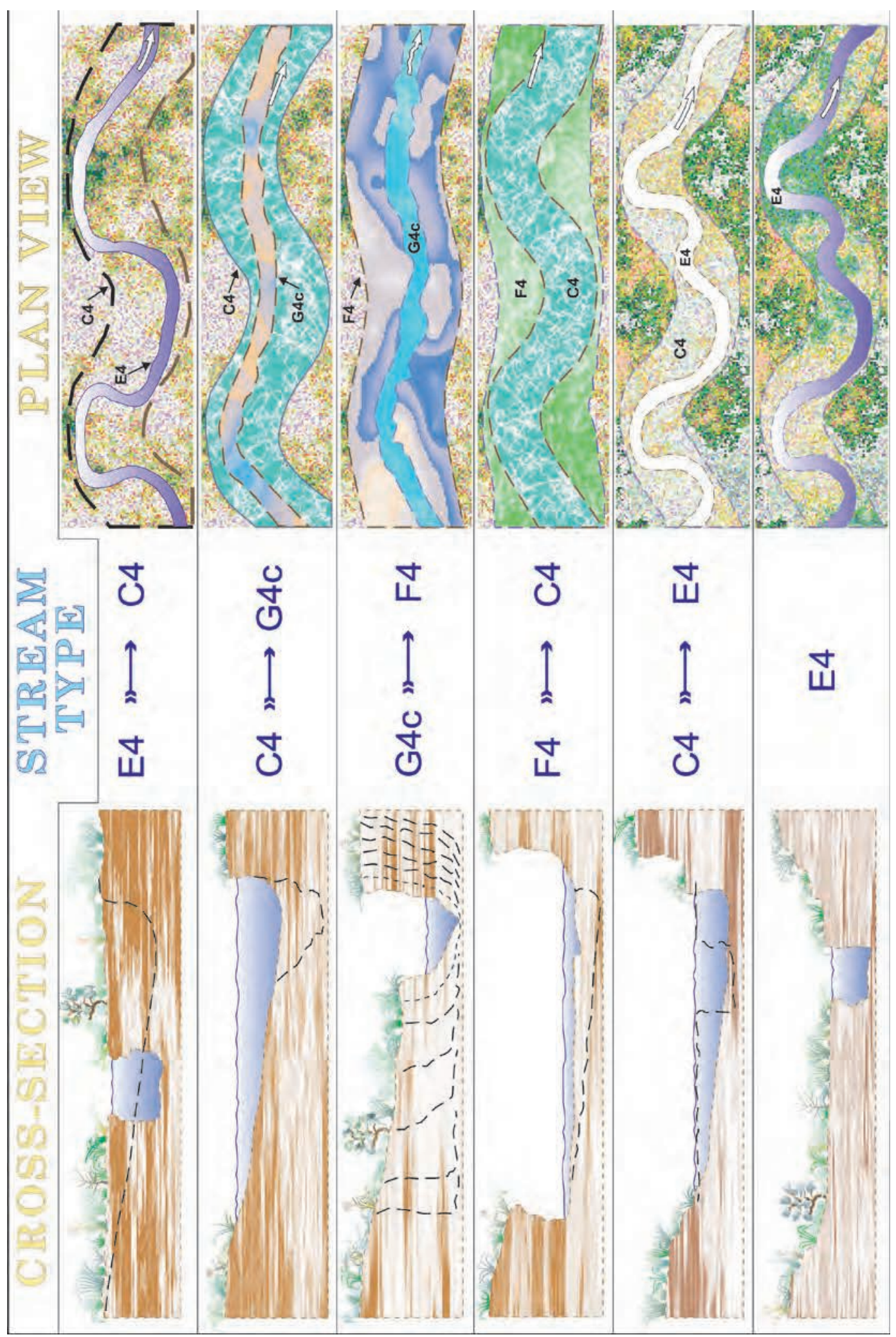

Figure 10. Stream channel succession and adjustment scenarios (Rosgen, 1996). 
bars, soft sediment, and bank erosion. Data from rapid-full sites on channel morphology, substrate, and bank erosion were used to further describe the spatial variability in 2013. Repeat photographs at rapid-limited sites helped to verify geomorphic responses, especially for signs of channel scour, bank erosion and bar deposition. Summary field assessment data by site is in appendix 4.

Some differences in expected changes were noted given that the 2012 flood was an extreme event and not a sustained long-term change in hydrology, as was the basis of the major geomorphic processes identified in the 2003-4 Duluth-area segment-scale classification. The pervasive occurrence of bar formation and coarse sediment deposition, especially in localities with flood-plain or channel-width constrictions, were the most notable differences for expected geomorphic processes (table 2). Bar formation was a dominant process at many of the segment categories in 2003-4, but the magnitude of the amount of coarse sediment deposition associated with the 2012 flood locally affected some steep bedrock sites as well.

The following sections describe the overall results in relation to Duluth segment-scale classification categories while also documenting the variability in the magnitude of the responses for the sampled sites. Examples of the longitudinal continuum of geomorphic responses are given for Mission Creek, Miller Creek, Lester River, and Keene Creek.

\section{Channel Morphology}

Changes in channel morphology varied across segment categories with some expected and unexpected outcomes. Three major sources of measurements were used to summarize channel morphology changes associated with the 2012 floodrepeat surveys of channel cross sections, bankfull width and depth measurements at intensive and rapid-full sites, and Rosgen Level II classification. The channel cross sections are useful for indicating the magnitude of lateral and vertical erosion and deposition. In general, there was more aggradation than expected in segment categories M.3 and M1 (table 2). Alternatively, a few sites in segment categories B and L2 had localized incision, indicating the power of the flood to transport even boulder-sized material.

Overlapping channel cross-section surveys were done mainly at riffles of three intensive sites - site 43 (Chester Creek, segment category M.3, fig. 11A), site 44 (Miller Creek, segment category B, figs. 11B and 11C), and site 31 (Lester River, segment category L1, figs. 11D and 11E). The cross section at site 43 (segment category M.3) verified aggradation, bank erosion, and widening in 2013. In contrast, site 44 (segment category B) had incision at both riffle and run cross sections in 2013, which was unexpected because of nearby bedrock control. Incision along this Miller Creek site has implications for a nearby sanitary sewer line that runs along the banks, as well as other infrastructure lines that cross the channel. Site 31 (segment category L1) had within-reach variability with localized aggradation at one cross section and incision at another. Bedrock banks remained unchanged at one riffle but eroded at the other cross section with unconsolidated banks. Of the three sites, site 43 has no bedrock control, whereas sites 44 and 31 have discontinuous bedrock along their banks and channel bottoms in places. Overall, the amount of vertical channel change was relatively small at these cross sections, in the order of plus or minus $( \pm) 30 \mathrm{~cm}$.

Another line of evidence for potential channel morphology change is outliers of channel bankfull cross-sectional area and width when plotted against drainage area. Post-2012 flood data at rapid-full and intensive sites indicates some variability in bankfull channel areas and widths within the same basins (fig. 12). Some unknown amount of variability may be due to difficulty in measurement of bankfull channel dimensions in an urban setting or sites with bedrock banks; however, the fit of a power function for a linear regression line (Helsel and Hirsch, 2002) was relatively good given the circumstances. Relatively larger channels than what might be expected included sites 23 and 31 (Lester River, segment categories M.3 and L1, respectively), site 44 (Miller Creek, segment category B), sites 38 and 39 (Mission Creek, segment categories A and L1, respectively), and site 52 (Keene Creek, segment category B) (fig. 12A). These channels were all more than 1.5 times larger than a nearby site, and site 39 was more than twice the size of nearby site 38 . Similarly, three of the six sites had relatively wide channel widths, all at sites without bedrock in segment categories M.3, L1, and A (fig. 12B). The lower main stem of Mission Creek seemed to be particularly wide compared to the other Duluth-area streams with similar drainage areas.

Using the Rosgen Level II calculations, four out of eight intensive sites with overlapping data changed stream types between 2003-4 and 2013 (table 3). The changes were in two metrics: width/depth ratio and entrenchment ratio. Site 34 (Miller Creek, segment category M.3) changed from an "E4b" stream type to a "C4," indicating widening of the channel (increase in the bankfull width/depth ratio from less than 12 to greater than 12). Similarly, site 1 (Mission Creek, segment category M1) changed from an "E3" to an "E4," indicating an increase in width and gravel substrate. Site 31 (Lester River, segment category L1) changed from stream type "C3" to "F3," indicating a change in the entrenchment ratio from slightly entrenched at greater than 2.2 to entrenched at less than 1.4. Gravel substrate increased at the expense of cobble at site 23 (Lester River, segment category M.3). These eight sites had Rosgen Level II stream types that have general sensitivity to disturbance from moderate to extreme (table 3 ).

\section{Channel Bed Substrate}

In general, the longitudinal continuum of Duluth-area segment-scale classification categories follow a pattern of channel bed substrate sizes, starting with fine-grained sediment (silt and sand) at wetland sites (segment categories $\mathrm{W}$ and W.3) as expected because of gentle reach slopes (fig. 13; 

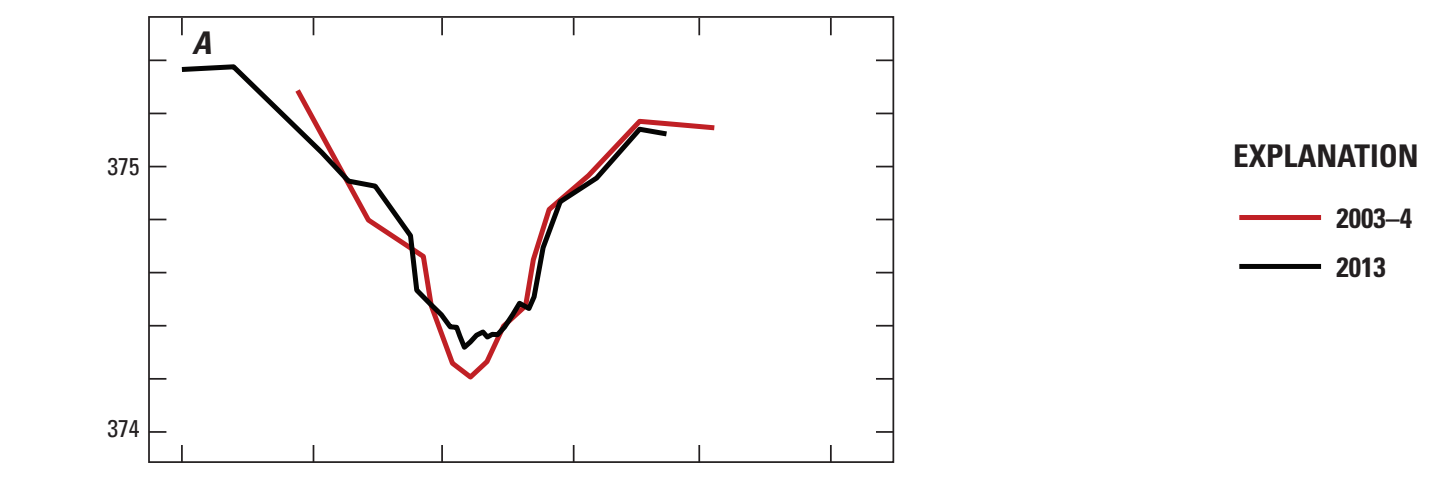

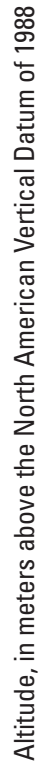

Site 43 (riffle number 1)
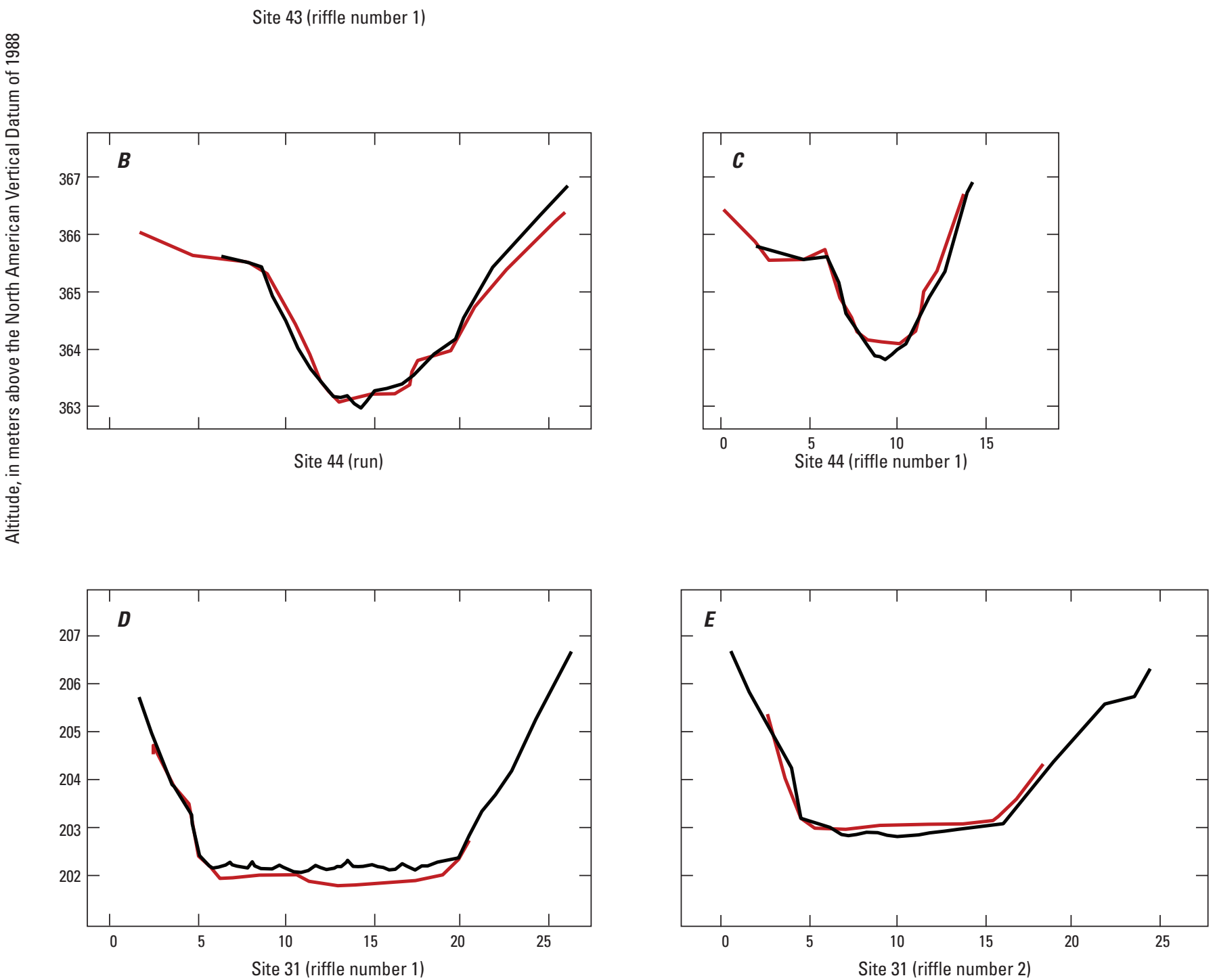

Distance from left side looking downstream, in meters

Figure 11. Overlays of 2003-4 and 2013 channel cross sections in riffles and runs at three sites (Lester River near Lester River Road, site 43; Miller Creek at Lake Superior College, site 44; and Lester River near Lester River Road, site 31) in the Duluth, Minnesota, area. $A$, site 43 (riffle number 1). $B$, site 44 (run). $C$, site 44 (riffle number 1). $D$, site 31 (riffle number 1). $E$, site 31 (riffle number 2). 


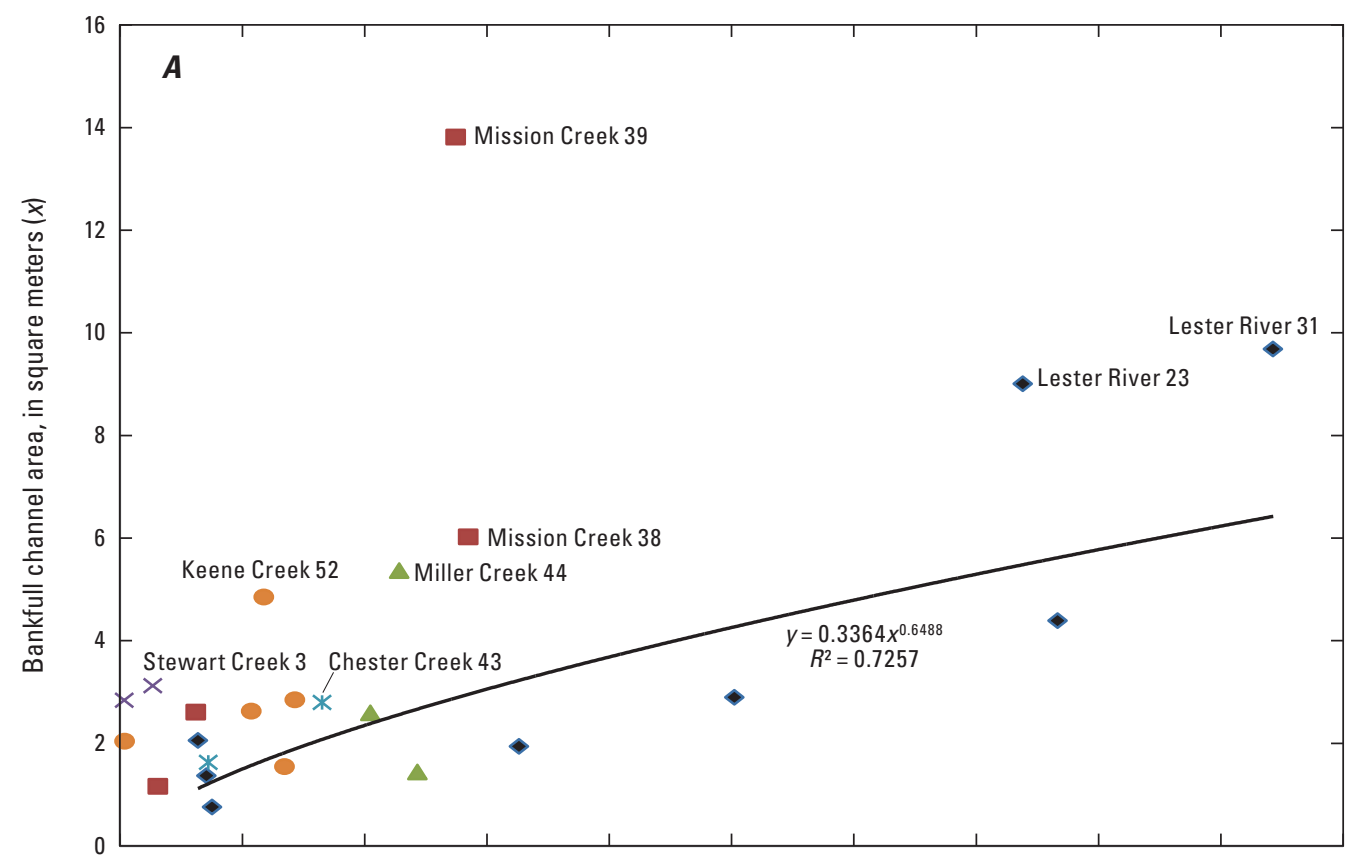

\section{EXPLANATION}

- Power function regression line for Lester River data

Stream name

- Lester River

* Chester Creek

$\triangle \quad$ Miller Creek

- Keene Creek

$\times \quad$ Stewart Creek

- Mission Creek

39 Site identifier

$R^{2}$ Coefficient of determination

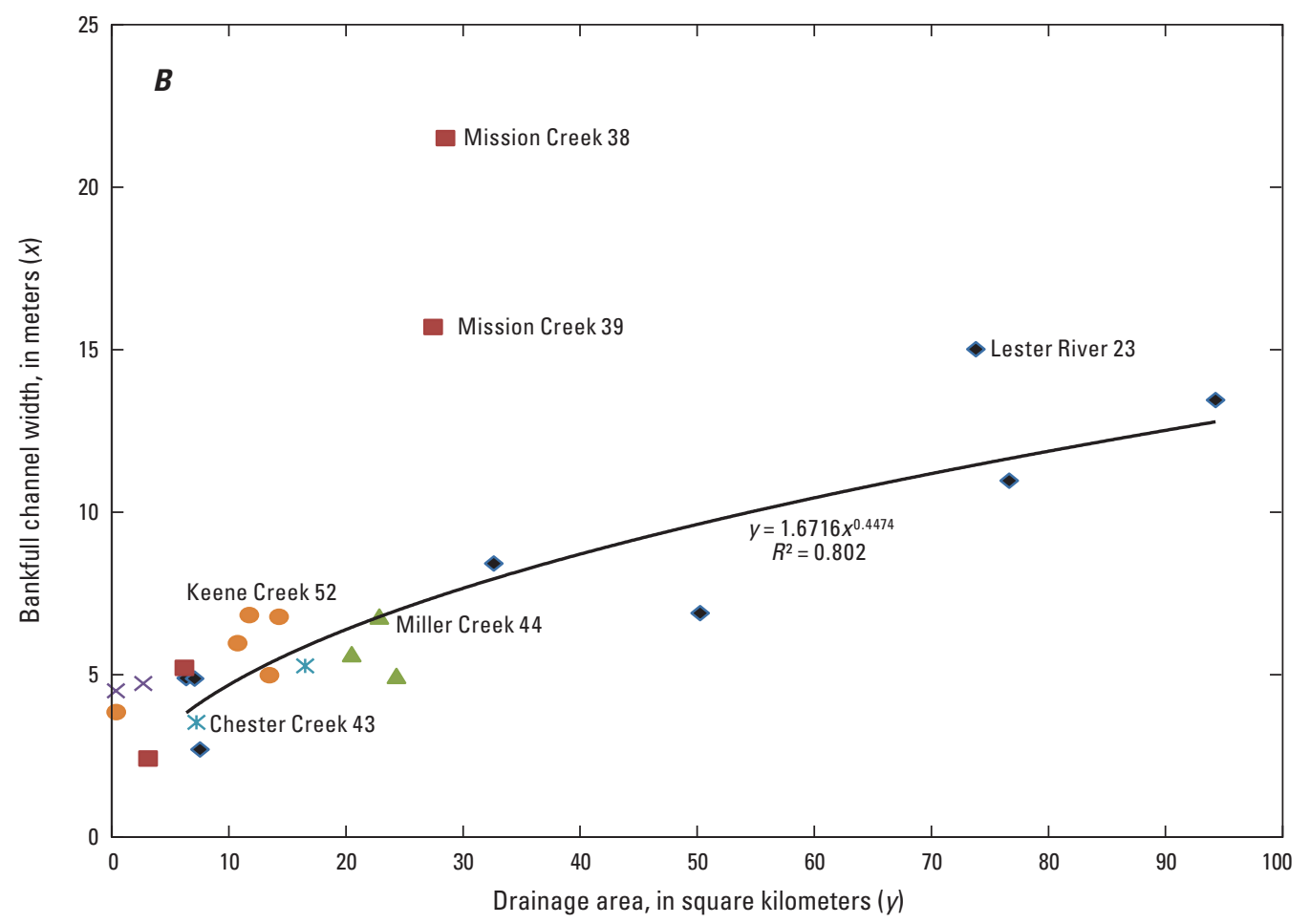

Figure 12. Relations between post-2012 flood bankfull channel characteristics for Duluth-area streams in 2013. $A$, bankfull channel area. $B$, bankfull channel width. 
Table 3. Summary of post-2012 dominant geomorphic processes and Rosgen Level II stream types for eight intensive sites with overlapping data from 2003-4 geomorphic assessments.

[Rosgen characteristics are from Rosgen (1994, 1996). Data for 2012 reach-specific 2013 field assessments and Rosgen metrics are found in appendix 4. USGS, U.S. Geological Survey; ID, identification; EBL, bluff erosion; EBA, bank erosion; W, widening; LM, lateral migration; BF, bar formation; A, aggradation; >, greater than; OS, overbank sedimentation; <, less than; ST, stable; NA, not applicable; EX, exansion of flow area; I, incision]

\begin{tabular}{|c|c|c|c|c|c|c|c|c|c|}
\hline $\begin{array}{c}\text { Geomorphic } \\
\text { assessment } \\
\text { site ID } \\
\text { number } \\
\text { (fig. 1) }\end{array}$ & Stream name & $\begin{array}{l}\text { Duluth } \\
\text { segment-scale } \\
\text { classification } \\
\text { category } \\
\text { (fig. 5) }\end{array}$ & $\begin{array}{c}\text { Geomorphic } \\
\text { responses to } \\
2012 \text { flood }\end{array}$ & $\begin{array}{c}\text { Rosgen } \\
\text { Level II } \\
\text { stream } \\
\text { type } \\
\text { 2003-4 } \\
\text { (fig. 9) }\end{array}$ & $\begin{array}{c}\text { Rosgen } \\
\text { Level II } \\
\text { stream } \\
\text { type } \\
2013 \\
\text { (fig. 9) }\end{array}$ & $\begin{array}{c}\text { Rosgen } \\
\text { general } \\
\text { sensitivity } \\
\text { to } \\
\text { distubance }\end{array}$ & $\begin{array}{l}2013 \text { Width/ } \\
\text { depth ratio }\end{array}$ & $\begin{array}{c}2013 \\
\text { Entrenchment } \\
\text { ratio }\end{array}$ & $\begin{array}{c}\text { Cause of } \\
\text { stream type } \\
\text { change }\end{array}$ \\
\hline 1 & $\begin{array}{r}\text { Mission Creek at } \\
\text { Stenman Road }\end{array}$ & M1 & $\begin{array}{c}\text { EBL, EBA, } \\
\text { W, LM, } \\
\text { BF, A }\end{array}$ & E3 & E4 & Very high & 10.42 & $>2.2$ & $\begin{array}{l}\text { Increasing } \\
\text { width, } \\
\text { increasing } \\
\text { gravel. }\end{array}$ \\
\hline 23 & $\begin{array}{l}\text { Lester River at } \\
\text { North Tischer } \\
\text { Road }\end{array}$ & M.3 & $\begin{array}{c}\text { EBL, EBA, } \\
\text { W, LM, } \\
\text { OS, BF }\end{array}$ & F3 & F4 & Extreme & 25.02 & $<1.4$ & $\begin{array}{c}\text { Increasing } \\
\text { gravel. }\end{array}$ \\
\hline 25 & $\begin{array}{l}\text { Lester River at } \\
\text { Arnold Road, } \\
\text { Number } 1\end{array}$ & $\mathrm{~W}$ & ST & $\mathrm{n} / \mathrm{a}$ & E5 & Very high & 9.64 & $>2.2$ & $\mathrm{n} / \mathrm{a}$ \\
\hline 31 & $\begin{array}{l}\text { Lester River near } \\
\text { Lester River } \\
\text { Road }\end{array}$ & L1 & $\begin{array}{l}\text { EBL, W, } \\
\text { OS, BF, A, } \\
\text { EX }\end{array}$ & C3 & F3 & Moderate & 18.68 & $<1.4$ & $\begin{array}{l}\text { Decreasing } \\
\text { entrench- } \\
\text { ment ratio. }\end{array}$ \\
\hline 34 & $\begin{array}{l}\text { Miller Creek } \\
\text { upstream from } \\
\text { Chambersburg } \\
\text { Avenue }\end{array}$ & M.3 & $\begin{array}{l}\text { EBA, W, } \\
\text { LM, OS, } \\
\quad \text { BF }\end{array}$ & $\mathrm{E} 4 \mathrm{~b}$ & $\mathrm{C} 4$ & Very high & 12.24 & $>2.2$ & $\begin{array}{l}\text { Increasing } \\
\text { width. }\end{array}$ \\
\hline 43 & $\begin{array}{c}\text { Chester Creek at } \\
\text { Triggs Road }\end{array}$ & M.3 & $\begin{array}{l}\text { EBA, W, } \\
\text { LM, OS, } \\
\text { BF, A }\end{array}$ & E4 & E4 & Very high & 7.67 & $>2.2$ & No change. \\
\hline
\end{tabular}




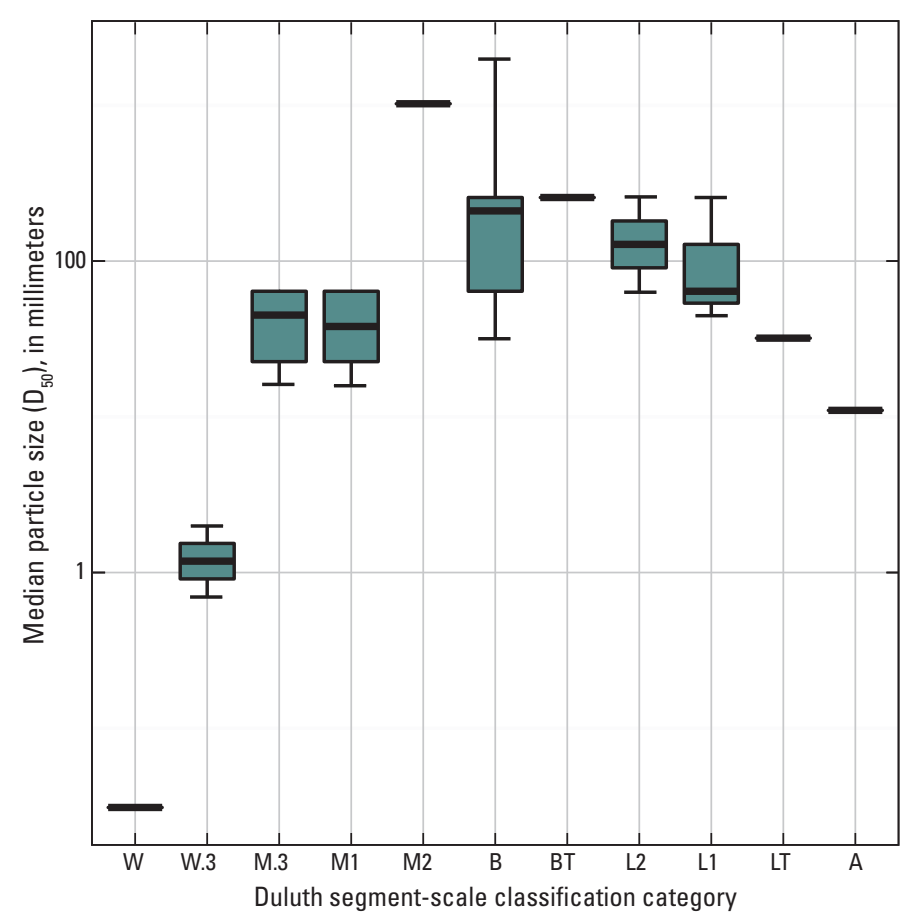

EXPLANATION

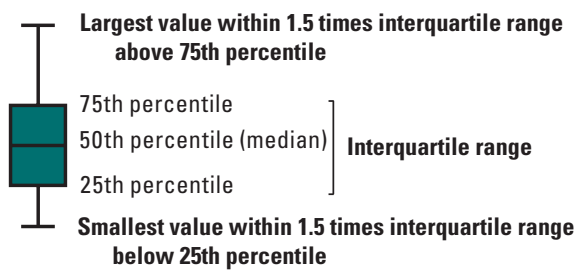

Figure 13. Median particle size by Duluth segment-scale classification category for intensive and rapid-full sites, 2013.

table 4). Middle main stems with moderate slopes have mostly gravel-sized substrate, whereas steep middle main-stem bedrock sites have cobble and larger median particle sizes. Lower main stems, with similar slopes as middle main stems, have coarser sizes because of their downstream proximity to steep sites and possibility of discontinuous bedrock near the surface. Aggradational sites have small gravel substrates. The full cumulative frequency plots are shown for intensive sites organized by segment category (figs. 14A-14D).

Seven intensive sites had overlapping pebble count data for riffles from 2003-4 and 2013. The seven sites were from four segment categories-M.3, M1, B, and L1. Riffle particle sizes at four of the seven sites were smaller in 2013 compared to 2003-4 (sites 1, 30, 31, and 34; fig. 15). These included segment categories M.3, M1, and L1. The largest size change was observed at Mission Creek site 1 (segment category M1) where the predominantly cobble and boulder-sized bed material observed in 2003-4 had transitioned to nearly all gravelsized material. In contrast, at site 44 (Miller Creek, segment category B) the distribution transitioned from about 80 percent of a range of gravel sizes to 60 percent medium to coarse gravel and 40 percent bedrock. The four sites in the M.3 segment category show the range in local variations; for example, site 34 had more sand and gravel in 2013, whereas site 43 had less sand and gravel.

\section{Exposed Bars and Soft Sediment Deposition}

For the 20 intensive sites measured in 2013, the areal extent of exposed bars (gravel and coarser sizes) and soft sediment (organic-rich silt and clay) were useful indications for nearby sediment supply, mode of sediment transport, and sediment transport capacity. No comparable measurements were made in 2003-4; however, some general statements can be made about their relation to the 2012 flood. The areal extent of exposed bars within the study sites was highly variable; for example, exposed bars ranged from 0 to more than 90 percent in the B segment-scale classification category (fig. 16A). The high percentage of bars at some of the sites in the B segment category was unexpected because of the steep slopes (table 4). Based on slope ranges and position within the stream network, it would be expected that segment categories M.3, M1, and L1 would have the highest amount of bars. Sites in segment categories W and W.3 with low slopes and low coarse-sediment supply (sites 25 and 40) had no exposed bars as expected. Sites with steep slopes may have a high amount of bars if the site is upstream from a constriction in channel width from a bridge or culvert (or where a section goes underground) that locally decreases water velocity and bedload transport. Another possibility is a locally excessive sediment supply from an upstream catastrophic valley-side failure. A photograph of site 52 (Keene Creek, segment category B) shows large boulders accumulated in the channel and along flood chutes adjacent to the channel (fig. 17A) between sections of scoured bedrock falls. This gives an indication of the power and depth of the floodwaters in Keene Creek, even with its relatively small drainage area of just less than 11 square kilometers $\left(\mathrm{km}^{2}\right)$. Keene Creek flows through an area with ample cobble and boulders in banks and terrace cuts. Soft sediment was present at the three wetland sites $(25,40$, and 33$)$ as expected (fig. 16B). Soft sediment covered 50 to 90 percent of the wetland sites, with average soft sediment thicknesses of 4 to $17 \mathrm{~cm}$ at site 25 (fig. 17B). One other site had notable soft sediment deposition—a lower main stem tributary (site 53). Site 53 had a relatively higher slope than the wetland sites, but soft sediment deposition was in a lengthy pooled section upstream from a rocky step (fig. 17C).

Photographs of site 52 (fig. 17A) and site 53 (fig. 17C) contrast the difference between the segment categories of $\mathrm{B}$ and LT. At site 53 (segment category LT), Coffee Creek flows through large cobble and boulders, yet the smaller drainage area and lower slope helped to keep the channel intact from scour or movement of the large substrate during the 2012 flood. Some of the rocks are scoured, but many remained moss covered and banks were not peeled back like at site 52 (Keene Creek, segment category B). 
Table 4. Slope, channel morphology, and substrate characteristics related to Duluth segment-scale classification categories for intensive, rapid-full, and rapid-limited geomorphic assessment sites.

[Comparable stream types for 2003 data are included for comparison.USGS, U.S. Geological Survey; ID, identification; Lidar, light detection and ranging; PR, pool riffle; PB, plane bed; SP, step-pool; CO, colluvial; BE, bedrock; CA, cascade; NS, not sampled ; WE, wetland; AR, artificial]

\begin{tabular}{|c|c|c|c|c|c|c|}
\hline $\begin{array}{l}\text { Duluth } \\
\text { segment-scale } \\
\text { classification } \\
\text { category } \\
\text { (fig. 5) }\end{array}$ & $\begin{array}{c}\text { Geomorphic } \\
\text { assessment } \\
\text { site ID } \\
\text { number } \\
\text { (fig. 1) }\end{array}$ & $\begin{array}{c}2013 \\
\text { Assessment } \\
\text { type } \\
\text { (fig. 1) }\end{array}$ & $\begin{array}{l}\text { Lidar reach } \\
\text { slope } \\
\text { (percent) }\end{array}$ & $\begin{array}{c}D_{50} \\
\text { particle size } \\
\text { (millimeters) }\end{array}$ & $\begin{array}{c}2013 \\
\text { Channel type }\end{array}$ & $\begin{array}{c}2013 \\
\text { Rosgen Level II } \\
\text { stream type } \\
\text { (fig. 9) }\end{array}$ \\
\hline M1 & 1 & Intensive & 1.21 & 22.6 & PR to $\mathrm{PB} / \mathrm{SP}$ & E4 \\
\hline $\mathrm{BT}$ & 2 & Rapid full & 14.76 & 256 & $\mathrm{CO} / \mathrm{BE} / \mathrm{CA}$ & АЗ + \\
\hline B & 3 & Rapid full & 12.05 & 64 & $\mathrm{BE} / \mathrm{CA}$ & АЗа + \\
\hline B & 4 & Rapid full & 4.41 & 256 & $\mathrm{BE} / \mathrm{CA}$ & B3a \\
\hline $\mathrm{BT}$ & 5 & Rapid full & 5.40 & 256 & CA & A3 \\
\hline M1 & 6 & Intensive & 1.24 & 22.6 & PR to long SP & B4c \\
\hline B & 7 & Rapid limited & 8.76 & NS & $\mathrm{BE}$ & A3 \\
\hline B & 8 & Rapid full & 10.32 & 2,000 & $\mathrm{BE}$ to $\mathrm{SP}$ & $\mathrm{A} 1 \mathrm{a}^{+}$ \\
\hline M2 & 9 & Rapid full & 2.72 & 1,024 & $\mathrm{BE} / \mathrm{SP}$ & $\mathrm{B} 2$ \\
\hline B & 10 & Intensive & 7.02 & 256 & $\mathrm{BE}$ & $\mathrm{B} 2 \mathrm{a}$ \\
\hline L1 & 11 & Intensive & 0.55 & 45 & $\begin{array}{l}\text { BE outcrop, } \mathrm{PB} \text { to } \\
\text { PR transition }\end{array}$ & B3c \\
\hline L1 & 13 & Rapid limited & 1.63 & NS & $\mathrm{PB} / \mathrm{BE}$ & $\mathrm{B} 2 \mathrm{c}$ \\
\hline $\mathrm{L} 2$ & 14 & Rapid full & 1.99 & 64 & $\mathrm{~PB}$ & B3 \\
\hline L1 & 15 & Rapid limited & 1.24 & NS & $\mathrm{PB}$ & B3c \\
\hline L1 & 16 & Rapid limited & 1.88 & NS & $\mathrm{PB} / \mathrm{BE}$ & B2c \\
\hline B & 17 & Rapid full & 7.07 & 2,000 & $\mathrm{BE}$ & B1a \\
\hline L1 & 18 & Rapid limited & 1.82 & NS & $\mathrm{BE} / \mathrm{PB} / \mathrm{SP}$ & B1c \\
\hline $\mathrm{L} 2$ & 19 & Rapid limited & 2.74 & NS & $\mathrm{BE}$ & B1 \\
\hline M1 & 20 & Rapid full & 1.24 & 64 & $\mathrm{~PB} / \mathrm{PR}$ & $\mathrm{C} 4$ \\
\hline M1 & 21 & Rapid full & 1.04 & 64 & $\mathrm{~PB} / \mathrm{PR}$ & $\mathrm{C} 4$ \\
\hline M1 & 22 & Rapid full & 1.16 & 64 & $\mathrm{PR} / \mathrm{PB}$ & B4c \\
\hline M.3 & 23 & Intensive & 0.33 & 45 & PR & F4 \\
\hline W.3 & 24 & Rapid full & 0.52 & 2 & $\mathrm{PR} / \mathrm{PB}$ & C5 \\
\hline W & 25 & Intensive & 0.02 & $<0.0625$ & $\begin{array}{c}\text { WE/active Beaver } \\
\text { Pond }\end{array}$ & E5 \\
\hline W & 26 & Rapid limited & 0.01 & NS & WE & C5c- \\
\hline W & 27 & Rapid limited & 0.13 & NS & WE & E5 \\
\hline W & 28 & Rapid limited & 0.26 & NS & WE & $\mathrm{C} 4$ \\
\hline W.3 & 29 & Rapid limited & 0.86 & NS & WE & C5 \\
\hline M.3 & 30 & Intensive & 0.74 & 64 & PB to PR & F3 \\
\hline L1 & 31 & Intensive & 1.07 & 64 & $\mathrm{BE}$ & F3 \\
\hline W.3 & 32 & Rapid limited & 1.00 & NS & WE & C5 \\
\hline W.3 & 33 & Intensive & 0.39 & 0.7 & $\mathrm{~PB} / \mathrm{PR}$ & E5 \\
\hline M.3 & 34 & Intensive & 0.59 & 16 & PR & $\mathrm{C} 4$ \\
\hline M1 & 35 & Rapid limited & 1.18 & NS & $\mathrm{PR} / \mathrm{SP}$ & B3c \\
\hline A & 36 & Rapid limited & 7.59 & NS & $\mathrm{CA} / \mathrm{PB} / \mathrm{AR}$ & A3 \\
\hline B & 37 & Intensive & 6.14 & 64 & $\mathrm{BE}$ & B3 \\
\hline A & 38 & Intensive & 0.85 & 11 & $\mathrm{~PB} / \mathrm{AR}$ & D4 \\
\hline
\end{tabular}


Table 4. Slope, channel morphology, and substrate characteristics related to Duluth segment-scale classification categories for intensive, rapid-full, and rapid-limited geomorphic assessment sites.-Continued

[Comparable stream types for 2003 data are included for comparison.USGS, U.S. Geological Survey; ID, identification; Lidar, light detection and ranging; PR, pool riffle; PB, plane bed; SP, step-pool; CO, colluvial; BE, bedrock; CA, cascade; NS, not sampled ; WE, wetland; AR, artificial]

\begin{tabular}{ccccccc}
\hline $\begin{array}{c}\text { Duluth } \\
\text { segment-scale } \\
\text { classification } \\
\text { category } \\
\text { (fig. 5) }\end{array}$ & $\begin{array}{c}\text { Geomorphic } \\
\text { assessment } \\
\text { site ID } \\
\text { number } \\
\text { (fig. 1) }\end{array}$ & $\begin{array}{c}\mathbf{2 0 1 3} \\
\text { Assessment } \\
\text { type } \\
\text { (fig. 1) }\end{array}$ & $\begin{array}{c}\text { Lidar reach } \\
\text { slope } \\
\text { (percent) }\end{array}$ & $\begin{array}{c}\mathbf{D}_{50} \\
\text { particle size } \\
\text { (millimeters) }\end{array}$ & $\begin{array}{c}\mathbf{2 0 1 3} \\
\text { Channel type }\end{array}$ & $\begin{array}{c}\text { 2013 } \\
\text { Rosgen Level II } \\
\text { stream type } \\
\text { (fig. 9) }\end{array}$ \\
\hline L1 & 39 & Rapid full & 1.22 & 256 & PB & B3c \\
W.3 & 40 & Intensive & 0.42 & $<0.0625$ & WE/AR?/PB & E6 \\
\hline M.3 & 41 & Rapid full & 0.70 & 64 & PB & E4 \\
\hline L2 & 42 & Rapid full & 2.07 & 256 & PB/AR & C3b \\
M.3 & 43 & Intensive & 0.78 & 22.6 & PR/SP & E4 \\
\hline B & 44 & Intensive & 1.77 & 32 & $\mathrm{CA} / \mathrm{SP}$ & $\mathrm{G} 4$ \\
\hline M1 & 45 & Intensive & 1.08 & 16 & $\mathrm{~PB} / \mathrm{AR}$ & $\mathrm{E} 4$ \\
\hline BT & 46 & Rapid limited & 7.19 & $\mathrm{NS}$ & $\mathrm{CO} / \mathrm{BE}$ & $\mathrm{A} 2$ \\
\hline BT & 47 & Rapid full & 3.66 & 256 & $\mathrm{BE} / \mathrm{SP}$ & $\mathrm{B} 2$ \\
\hline BT & 48 & Rapid limited & 9.17 & $\mathrm{NS}$ & $\mathrm{BE} / \mathrm{CO}$ & $\mathrm{A} 2$ \\
\hline B & 49 & Intensive & 5.85 & 38 & $\mathrm{BE} / \mathrm{SP}$ & $\mathrm{B} 4 \mathrm{a}$ \\
\hline A & 51 & Intensive & 0.33 & 11 & $\mathrm{PR}$ & $\mathrm{C} 4$ \\
\hline B & 52 & Intensive & 6.27 & 210 & $\mathrm{SP}$ & $\mathrm{A} 2$ \\
\hline LT & 53 & Intensive & 1.80 & 32 & $\mathrm{BE}, \mathrm{SP}, \mathrm{PR}$ & $\mathrm{B} 4 \mathrm{c}$ \\
\hline
\end{tabular}

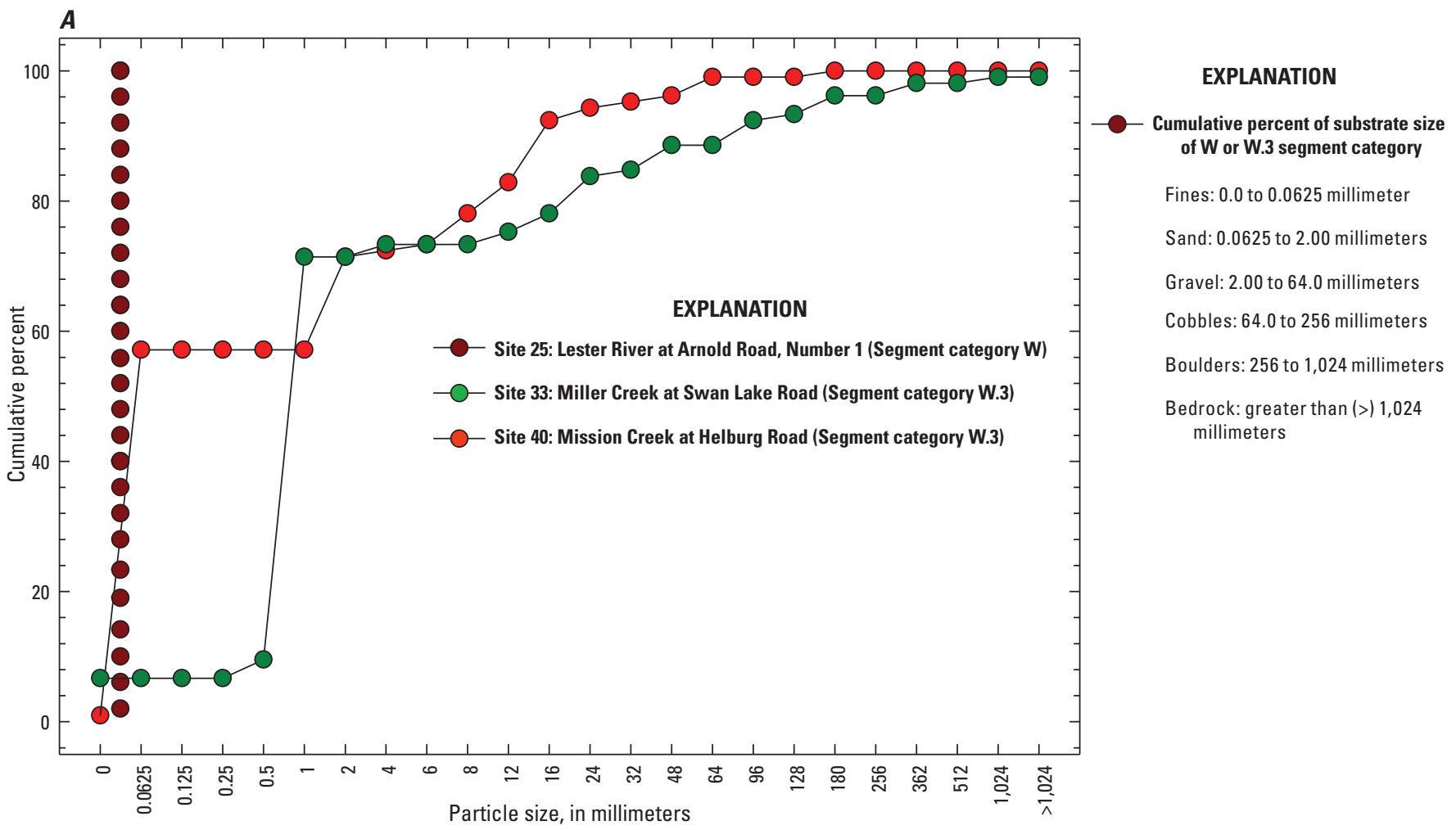

Figure 14. Cumulative frequency plots of substrate particle size (pebble counts) at 2013 intensive sites in the Duluth, Minnesota, area grouped by Duluth segment-scale classification category. A, W or W.3. B, M.3, M1, or M2. C, B, BT, L2, L1, or LT. D, A. 


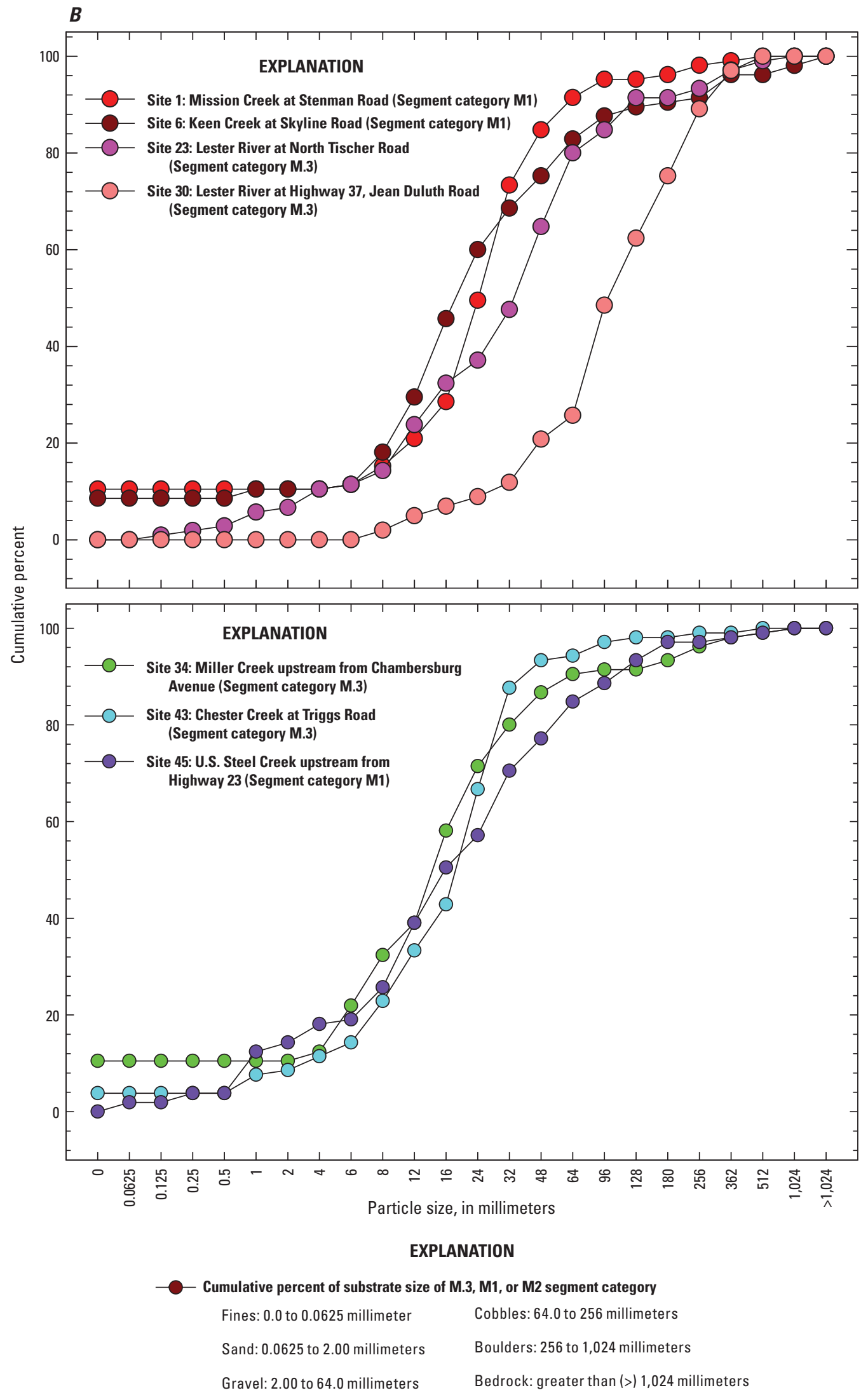

Figure 14. Cumulative frequency plots of substrate particle size (pebble counts) at 2013 intensive sites in the Duluth, Minnesota, area grouped by Duluth segment-scale classification category. $A, W$ or W.3. B, M.3, M1, or M2. C, B, BT, L2, L1, or LT. D, A.—Continued 


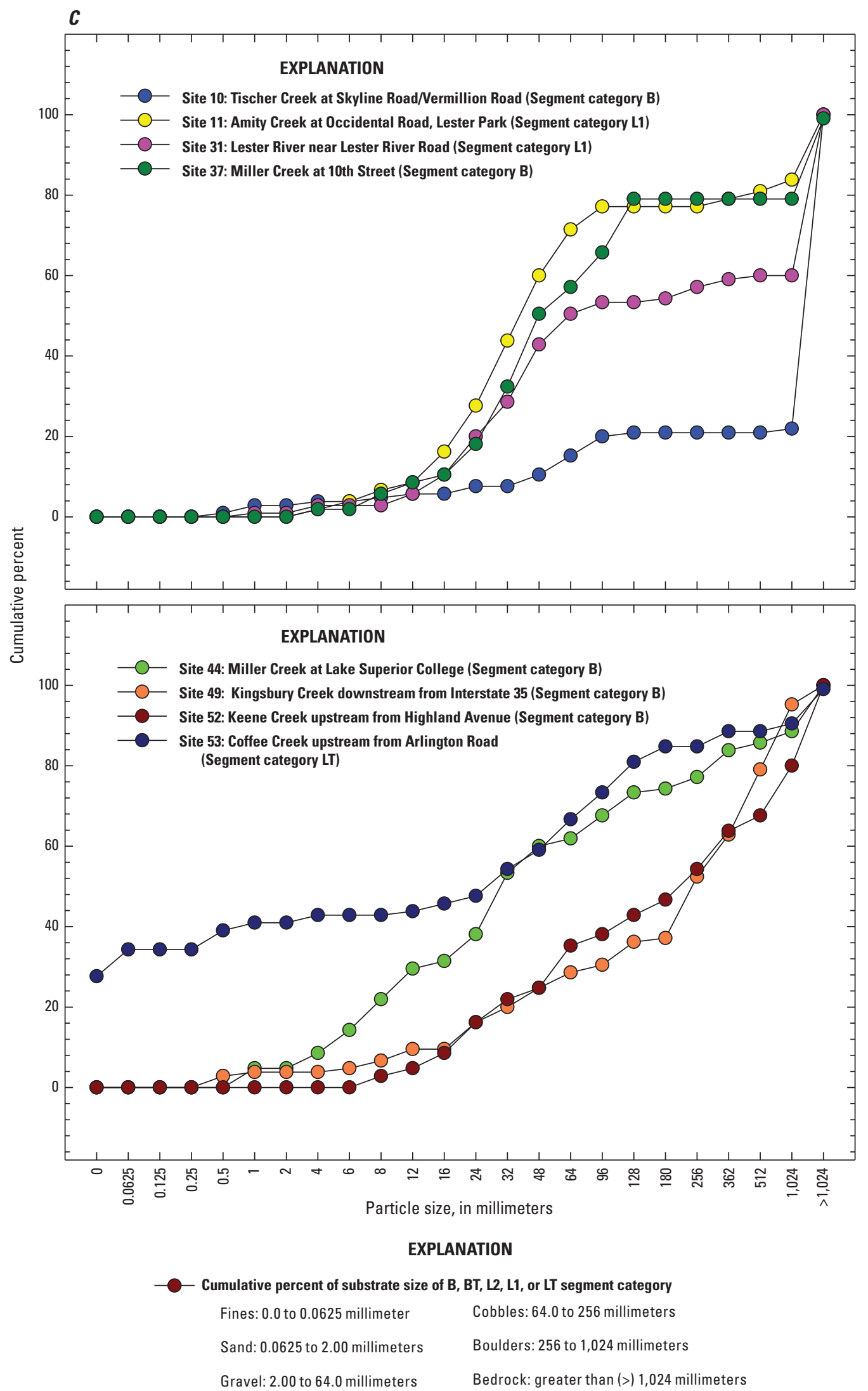

Figure 14. Cumulative frequency plots of substrate particle size (pebble counts) at 2013 intensive sites in the Duluth, Minnesota, area grouped by Duluth segment-scale classification category. $A, W$ or W.3. B, M.3, M1, or M2. C, B, BT, L2, L1, or LT. D, A.-Continued 


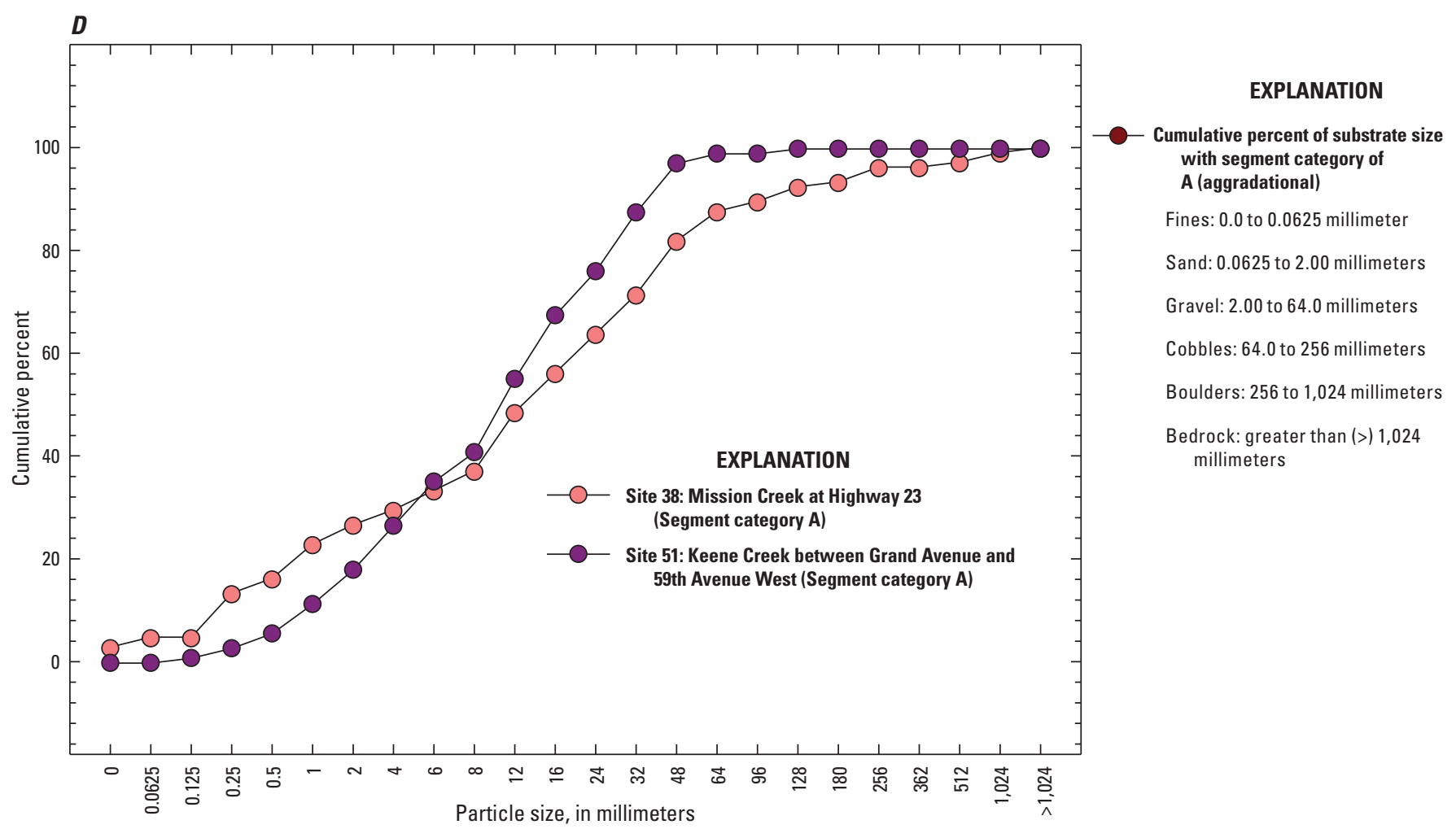

Figure 14. Cumulative frequency plots of substrate particle size (pebble counts) at 2013 intensive sites in the Duluth, Minnesota, area grouped by Duluth segment-scale classification category. A, W or W.3. B, M.3, M1, or M2. C, B, BT, L2, L1, or LT. D, A.-Continued

\section{Large Wood}

The 2012 flood reduced the amount of large wood and potentially altered the function of the wood in regard to channel bedforms in all eight intensive sites with 2003-4 and 2013 comparison data (fig. 18A). These sites included five segment categories (W, M.3, M1, B, and L1) that span the longitudinal continuum of headwaters to lower main stems. The decreases in wood were expected in all but the $\mathrm{W}$ segment category. The middle main stems (M.3 and M1) had the largest frequency of wood counts in 2003-4, ranging from 40 to near 160 pieces of wood per 150-m reach. In addition, middle main stem site 23 had a large log jam (about 70 cubic meters $\left[\mathrm{m}^{3}\right]$ —data not included in figure 18A) that was moved out of the reach by the 2012 flood. The wetland site 25 had similar counts as the lower range for the middle main stem sites in 2003-4. The ponded water and soft sediment in 2013 at site 25 may have obscured the wood that was easier to identify in 2003-4. The lower main stem sites were just slightly near or less than 40 pieces per reach length. Keeping in mind that data are limited to three middle main stem sites, wood function may have also changed in response to the 2012 flood, indicating that multiple complex functions had been reduced or eliminated (fig. 18A).

When looking at the full number of intensive sites for 2013 only, the function of most of the large wood is for bank stability in all segment categories (fig. 18C). Bar stabilizing attributes were at sites in four segment categories (W.3, LT,
M.3, and L1). Only three sites (31, 37, and 43), in segment categories M.3, B, and L1 had a few pieces of wood that were functioning as a step former. These sites had gentle slopes around 1.0 percent or less to more than 6 percent in the bedrock category (table 4).

\section{Pools}

For the eight intensive sites with measured pools in 2003-4 and 2013, middle main stems (segment categories M.3 and M1) had a large reduction in pool frequency after the 2012 flood (fig. 19A). Most notable was site 43, which went from 21 pools in 2003-4 to 3 in 2013 (86-percent reduction). Four sites-1, 23, 34, and 43-also had decreases in large wood, some of which was forming pools (figs. 18A and 19A). Site 1, which went from 17 pools to 1 pool, also had potential losses from gravel deposition. It is likely that these sites lost pools because of a combination of decreases in large wood and deposition of gravel.

In 2013, pools were still most frequent in middle main stems (segment categories M.3 and M1) and bedrock (segment cateogory B) sites compared to headwater wetlands (segment categories W and W.3) and especially lower main stems (segment category L1) (fig. 19B). The relatively large number of pools in middle main stems is likely attributable to slope, related channel bedforms (pool-riffle and step-pool), and large wood. For bedrock sites, pools likely are caused by scour 
Site 1 (segment category M1)

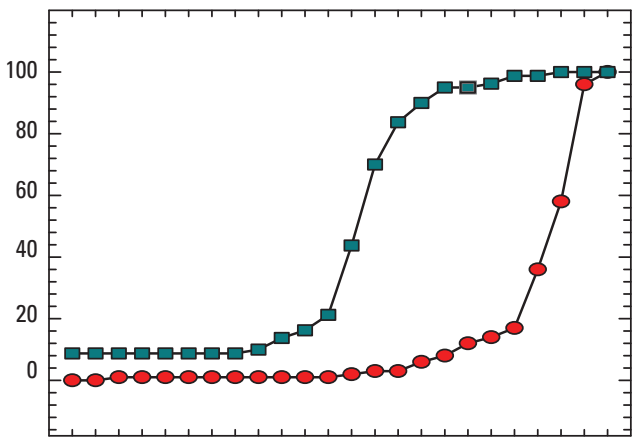

Site 30 (segment category M.3)

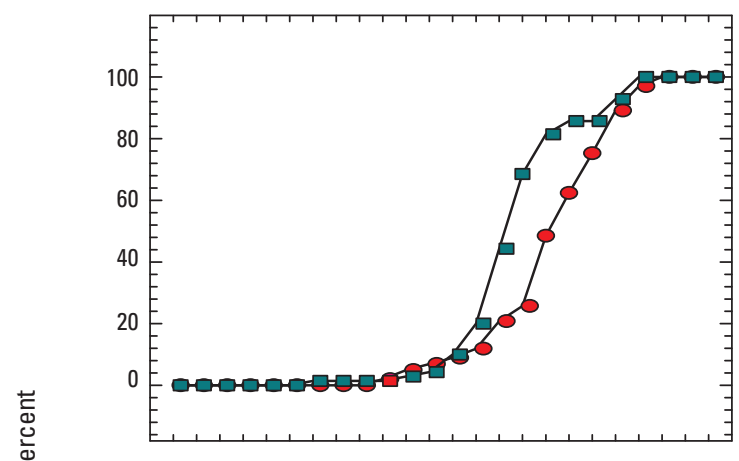

Site 34 (segment category M.3)

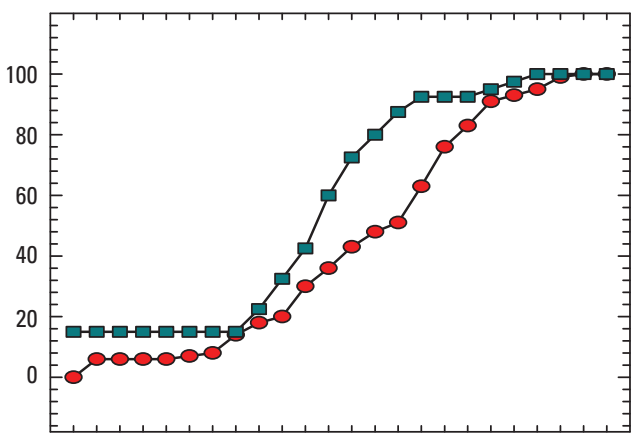

Site 44 (segment category B)

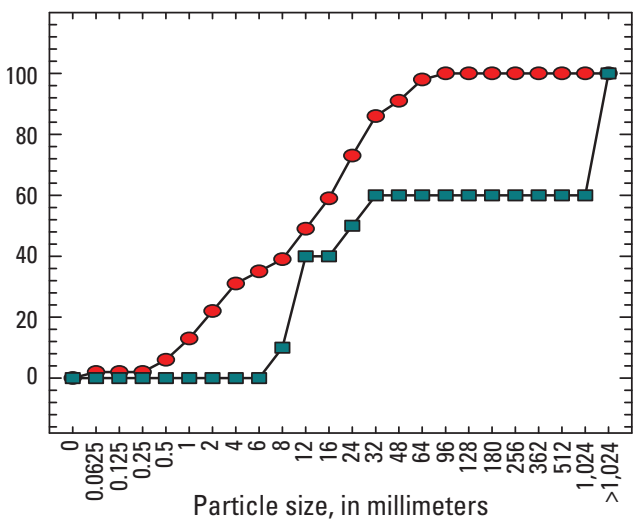

Site 23 (segment category M.3)

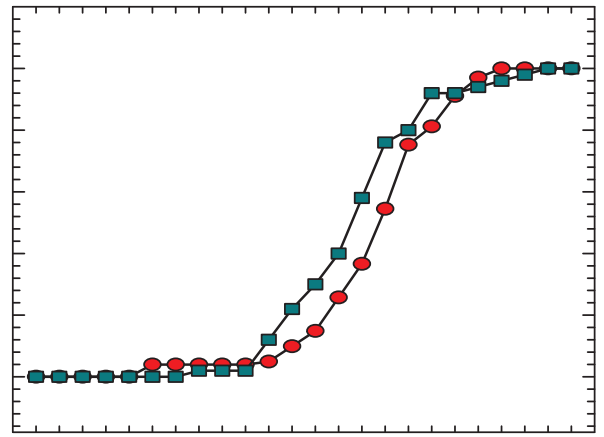

Site 31 (segment category L1)

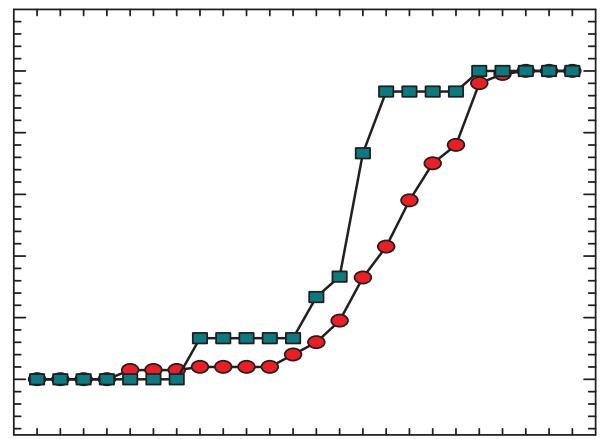

Site 43 (segment category M.3)

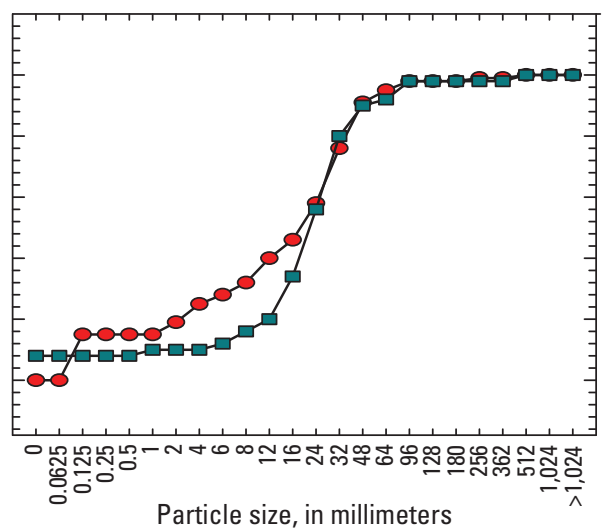

EXPLANATION

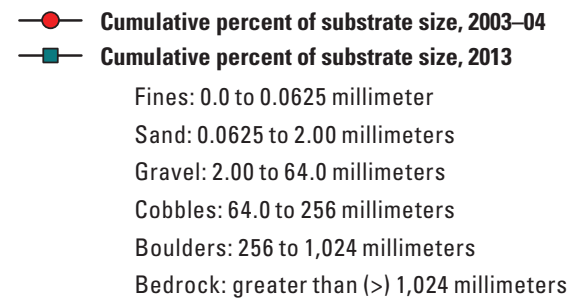

Figure 15. Comparison of pebble count data in overlapping riffles, 2003-4 to 2013. 

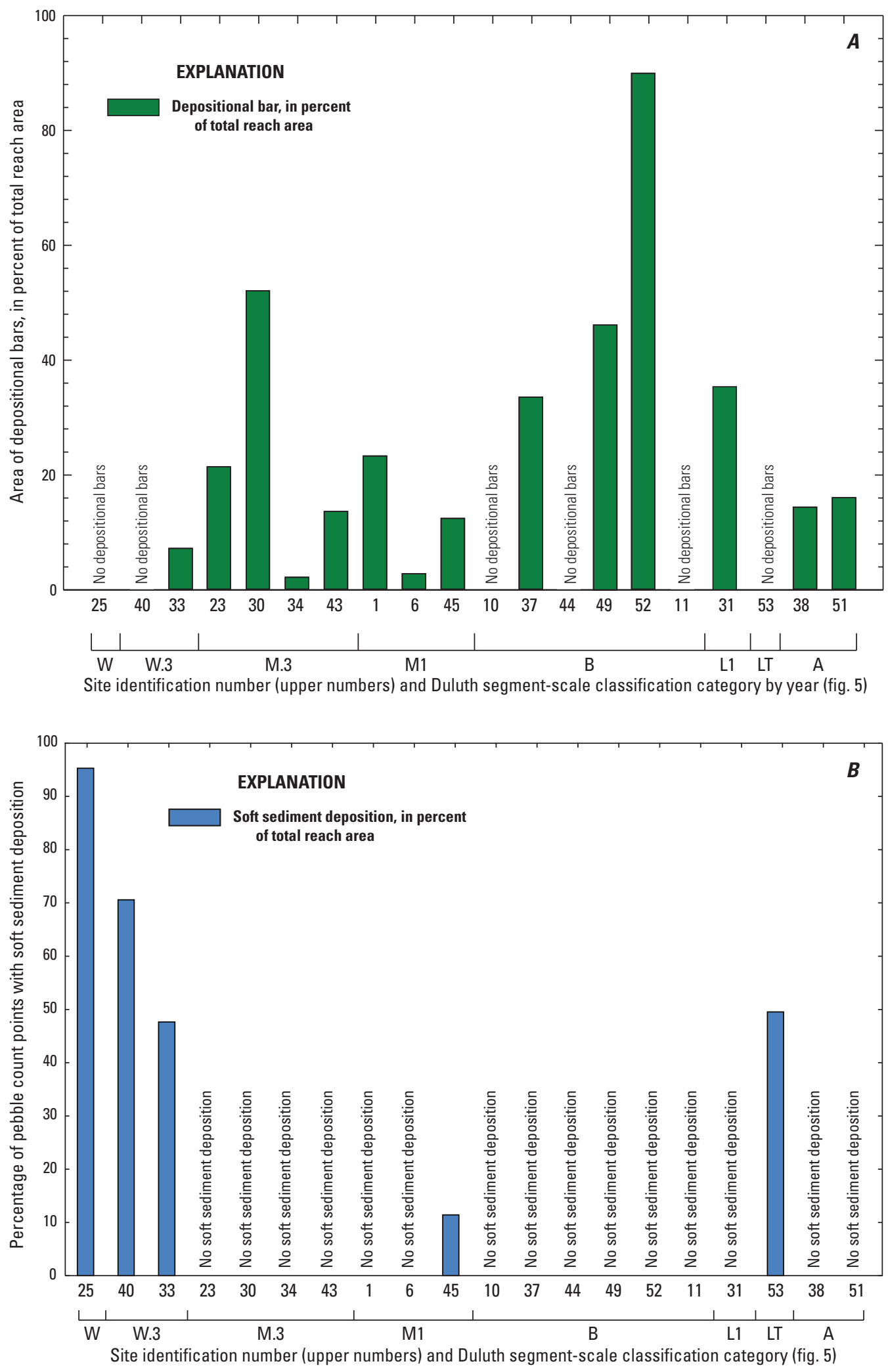

Figure 16. Percentage of reach area for 2013 intensive sites in the Duluth, Minnesota, area. $A$, area of depositional bars. $B$, percentage of pebble count points with soft sediment deposition. 


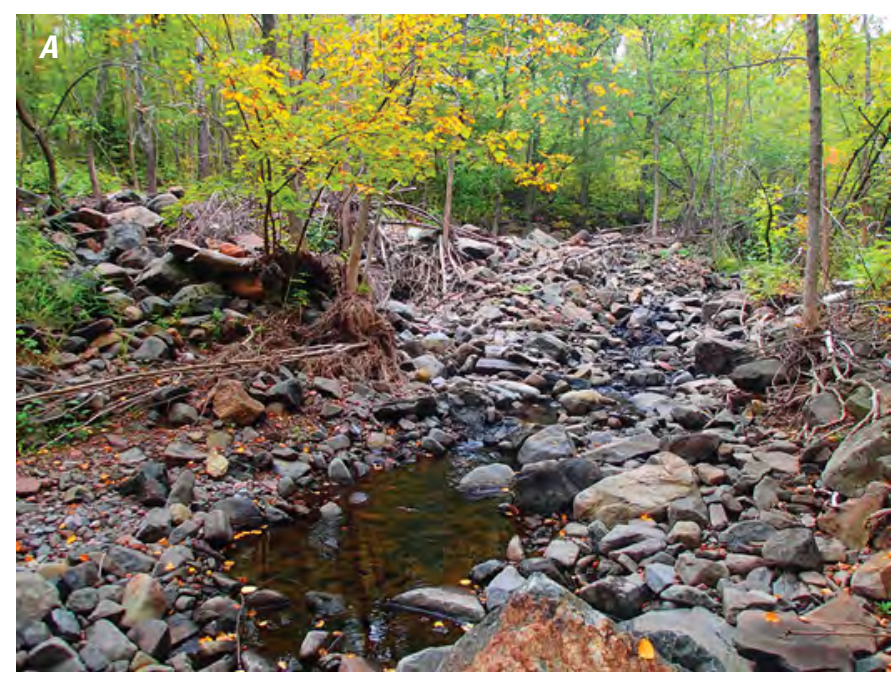

B
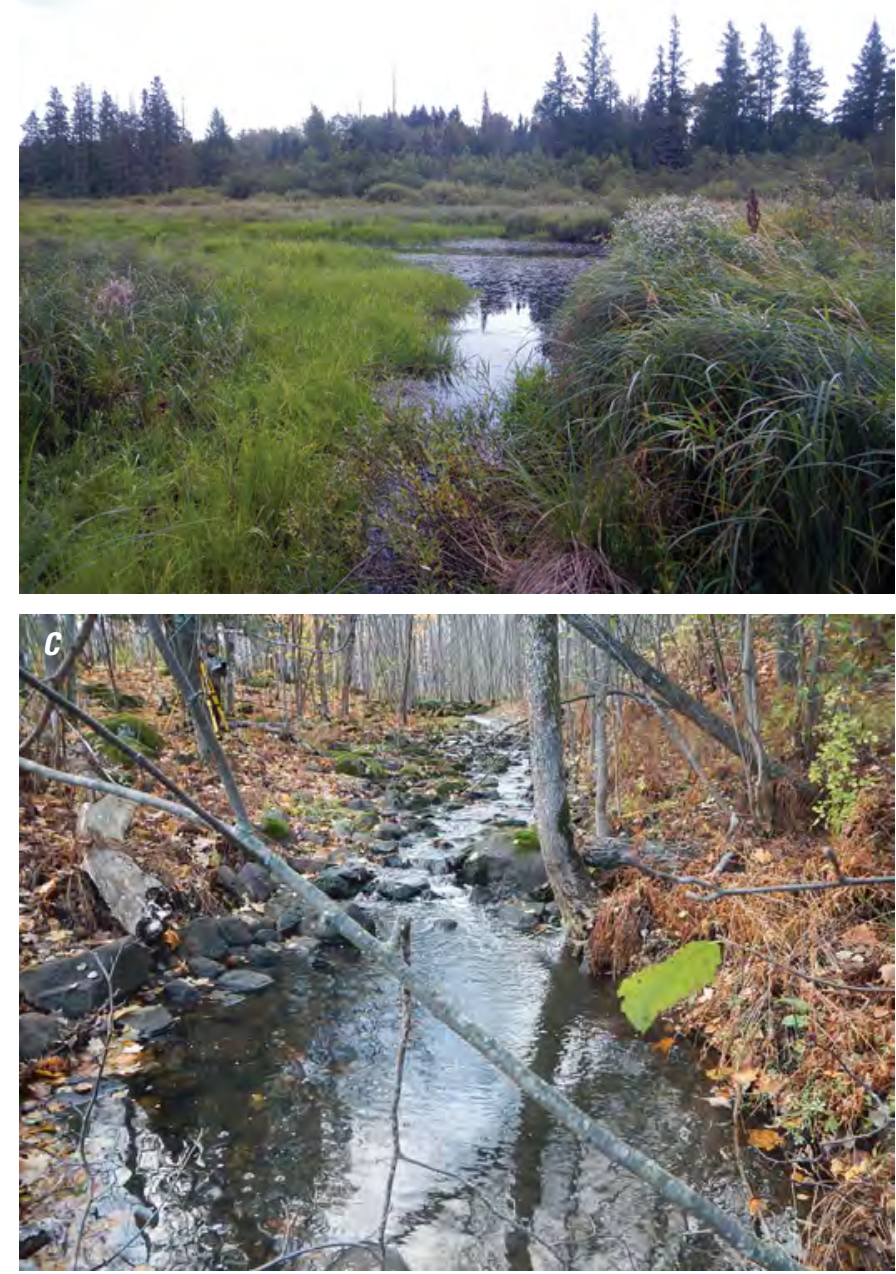

Figure 17. Sites 52 (Keene Creek upstream from Highland Avenue), 25 (Lester River at Arnold Road, Number 1), and 53 (Coffee Creek upstream from Arlington Road). A, bar deposition and coarse bed material deposited during the 2012 flood at site 52. $B$, wetland setting at site 25 . $C$, pools with soft sediment deposition at site 53 . zones below bedrock falls and rapids. Four of the intensive sites (23, 30, 34, and 45), all middle main stems, had large wood-forced pools, reinforcing the importance of large wood on providing additional pool structure. Middle main stems also had the most planebed channel types, which is also a potential sign of a lack of large wood and excessive gravel supply, that overruns potential pool-riffle or step-pool channel bedform types along the same slope ranges (table 4; fig. 4).

\section{Bank, Terrace, and Bluff Erosion}

Measurements of recently eroding banks, terraces, and bluffs at 36 intensive and rapid-full sites indicated that wetland (segment categories W and W.3) and main-stem bedrock (segment categories B) sites had the least amount of erosion and middle and lower main stems (segment categories M.3, M1, M2, L2, L1, A) had the most (fig. 20). Low amounts of bank erosion are expected in wetland streams with no valley development where low slopes limit the amount of erosive forces that can act on thickly vegetated low banks (fig. 4). Bedrock sites have mostly erosion-resistant bedrock sides, limiting the amount of erosion. Middle main stems and lower main stems with entrenched valleys have the highest amount of erosion because of the proximity of valley sides to the channel meanders with moderate to steep slopes and ample flood flows. Sites that had relatively high amounts of eroding banks, such as site 14, functioned as sources of coarse material—gravel, cobble, and boulders - to downstream sites during the 2012 flood (figs. 21A and 21B). Sites 14 and 42 (Amity Creek and Keene Creek, respectively; both from segment category L2) had full range of erosion between them; site 42 had no erosion compared to a high of 5 square meters $\left(\mathrm{m}^{2}\right)$ per meter of reach length for site 14. Even though the slope of site 42 was similar to site 14 at 2 percent, and both are along lower main stems, there are multiple local factors that account for less erosion at site 42-the reach is in an alluvial valley setting, banks have been artificially hardened with large rock and planted trees, and the drainage area is less than one-half that of site 14 (fig. 21C; table 1).

\section{Longitudinal Continuum of Geomorphic Responses to the 2012 Flood}

Plotting a comparison of 2003-4 and 2013 photographs of representative sites along the longitudinal profiles of Lester River, Miller Creek, Mission Creek, and Keene Creek illustrate how geomorphic responses to the 2012 flood reflected segment categories in an upstream to downstream progression (fig. 22). Along Lester River (fig. 22A), the upper main stem flows through wetlands, with gentle slopes and ditches (site 25), which had little change after the 2012 flood. Farther downstream, the entrenched valley is cut into glacial outwash and ice-contact deposits, and the slope increases (sites 30 and 23). Evidence of valley side failures and landslides were present, and bank erosion and widening were common outcomes 

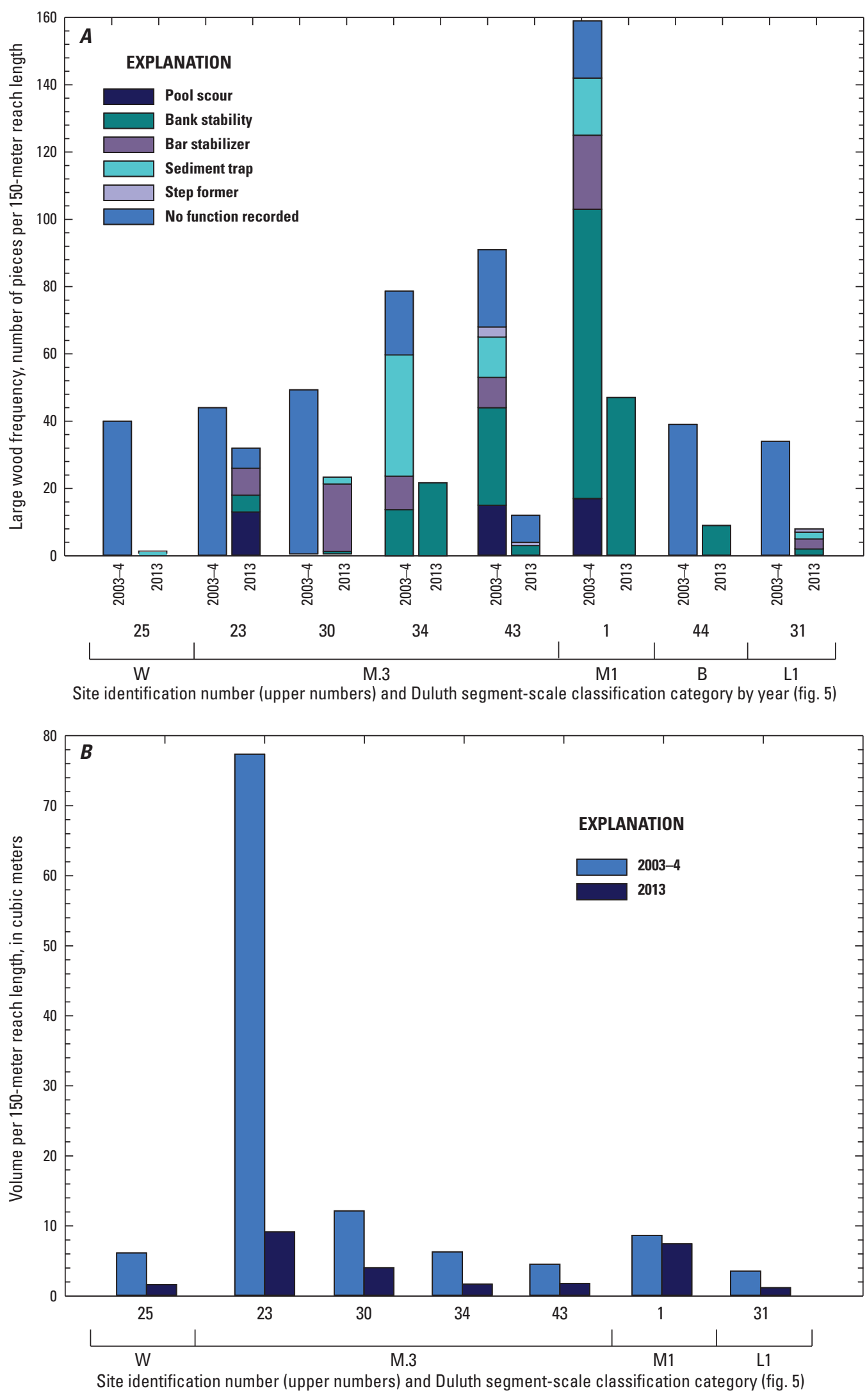

Figure 18. Large wood per 150-meter reach length at intensive sites. $A$, comparison of frequency and function at 2003-4 and 2013 intensive sites. B, comparison of volume of wood at 2003-4 and 2013 intensive sites. $C$, frequency and function at all 2013 intensive sites. 


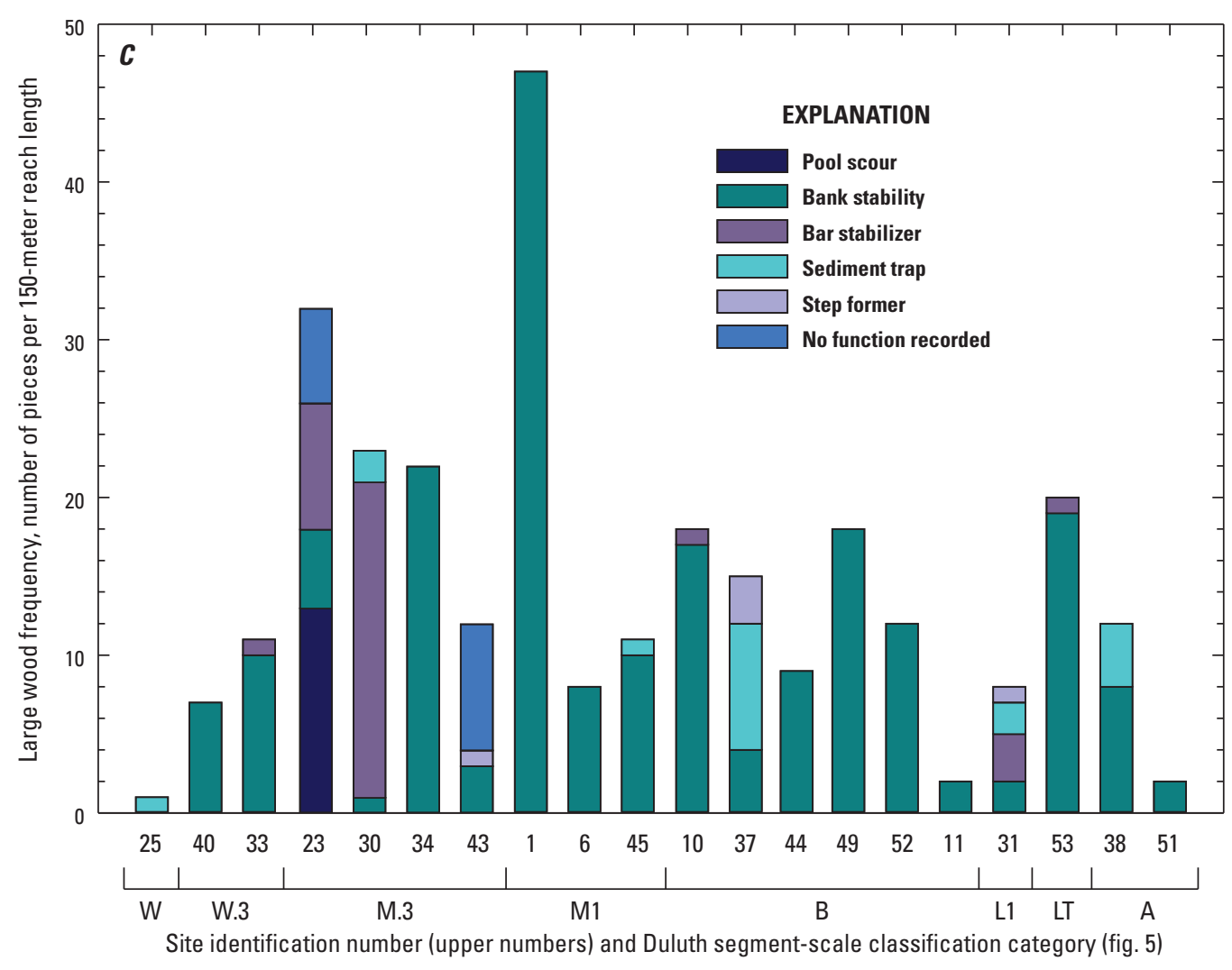

Figure 18. Large wood per 150-meter reach length at intensive sites. $A$, comparison of frequency and function at 2003-4 and 2013 intensive sites. $B$, comparison of volume of wood at 2003-4 and 2013 intensive sites. $C$, frequency and function at all 2013 intensive sites.-Continued from the 2012 flood. It is likely that, at about this point along the main stem, tributaries and the middle main stem became sediment sources. Sediment deposition in the channel and in overbank areas was more common at site 23 than at site 30 , along with large wood jams (table 4-1). The channel showed signs of widening, and bank erosion was common, but there was less lateral migration, and valley side failures were less common than upstream. Farther downstream at site 31, the steep bedrock channel showed scour along channel margins and channel expansion. In 2003-4, site 31 functioned as a transfer zone, and sediment and large wood were transported through the reach and downstream. In 2013 there was more bar deposition than expected, possibly because of the severity of the flood or local channel constrictions caused by bridges downstream.

The length of Miller Creek is much less than Lester River, but Miller Creek also begins with gently sloping wetland ditches (site 33, fig. 22B) that had little change after the 2012 flood. Downstream, site 34 is in the transition from glacial deposits to bedrock and in 2003-4 had evidence for recent (within 5 years) channel widening, avulsion (sudden channel movement), and flood scour, likely from urbanization in the immediate basin. In 2013, geomorphic processes were similar to those in 2003-4 (table 4-1). Downstream, in the steep reach affected by Duluth-complex gabbro bedrock (site 44), the cascade-type channel showed signs of expansion in the channel flow area in sites with bedrock banks or channel widening in areas with unconsolidated banks. Site 34 functioned mainly as a transfer reach for upstream sources of sediment and upstream or bank-derived large wood. Artificially-placed rock kept incision to a minimum. Sites 7 and 37 downstream are examples of bedrock channels with slopes greater than 6 percent. Site 37 had bar formation from the 2012 flood. Downstream from the bedrock-controlled zone, the channel had an artificial planebed at site 36 . This reach had major accumulations of coarse sediment after the 2012 flood.

The longitudinal profile for the middle main stem of Mission Creek (fig. 22C) is more concave than the profiles for Lester River (fig. 22A) and Miller Creek (fig. 22B) because Mission Creek flows through sedimentary rock instead of the Duluth Complex bedrock (fig. 7), although the upper main stems of the three creeks have similar low slope wetlands. Near the lower end of Mission Creek, in an area of slight steepening after the washout of a brush catcher (fig. 23), site 39 had extensive erosion during the 2012 flood, and site 38 farther downstream had widening and bar deposition.

The Keene Creek longitudinal profile is representative of a smaller tributary with some wetland and low slope sites that quickly transition to a very steep middle main stem flowing on gabbro intrusive bedrock (fig. 22D). Lower main-stem sites had substantial gravel accumulation and aggradation after the 2012 flood such as shown in the comparison photographs of site 42 (fig. 22D). 


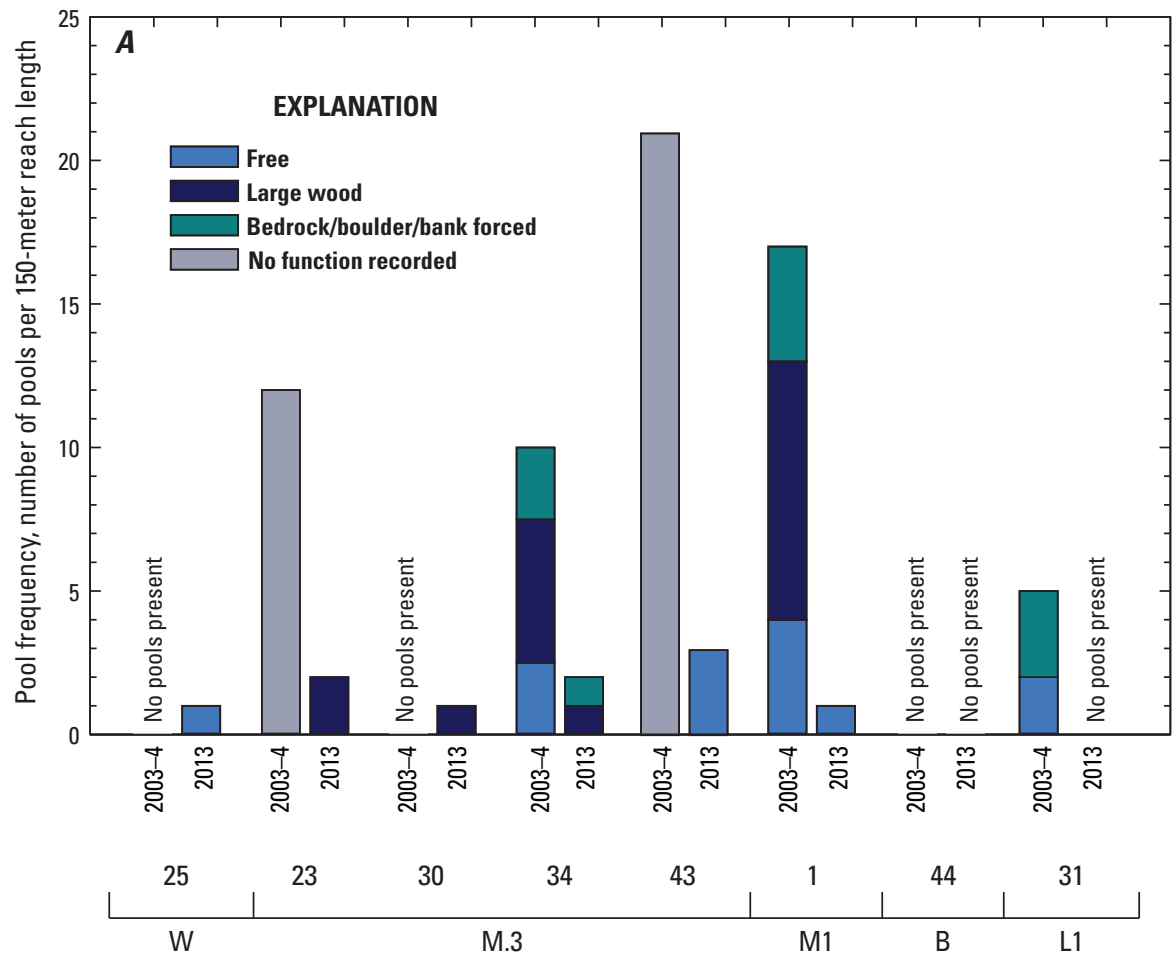

Site identification number (upper numbers) and Duluth segment-scale classification category by year (fig. 5)

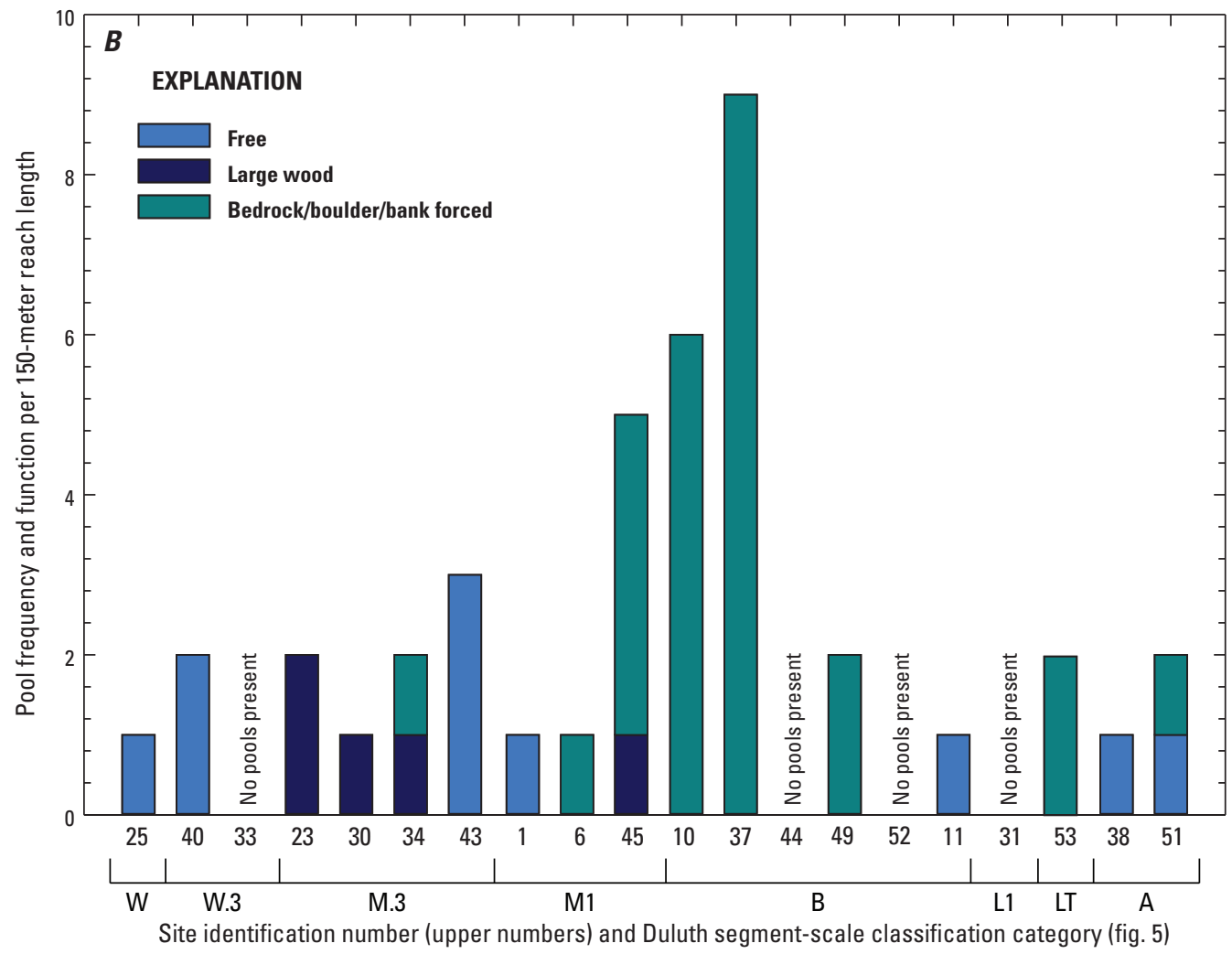

Figure 19. Comparison of pool frequency and function per 150-meter reach length at intensive sites in the Duluth, Minnesota, area. A, 2003-4 and 2013 intensive sites. B, all 2013 intensive sites. 


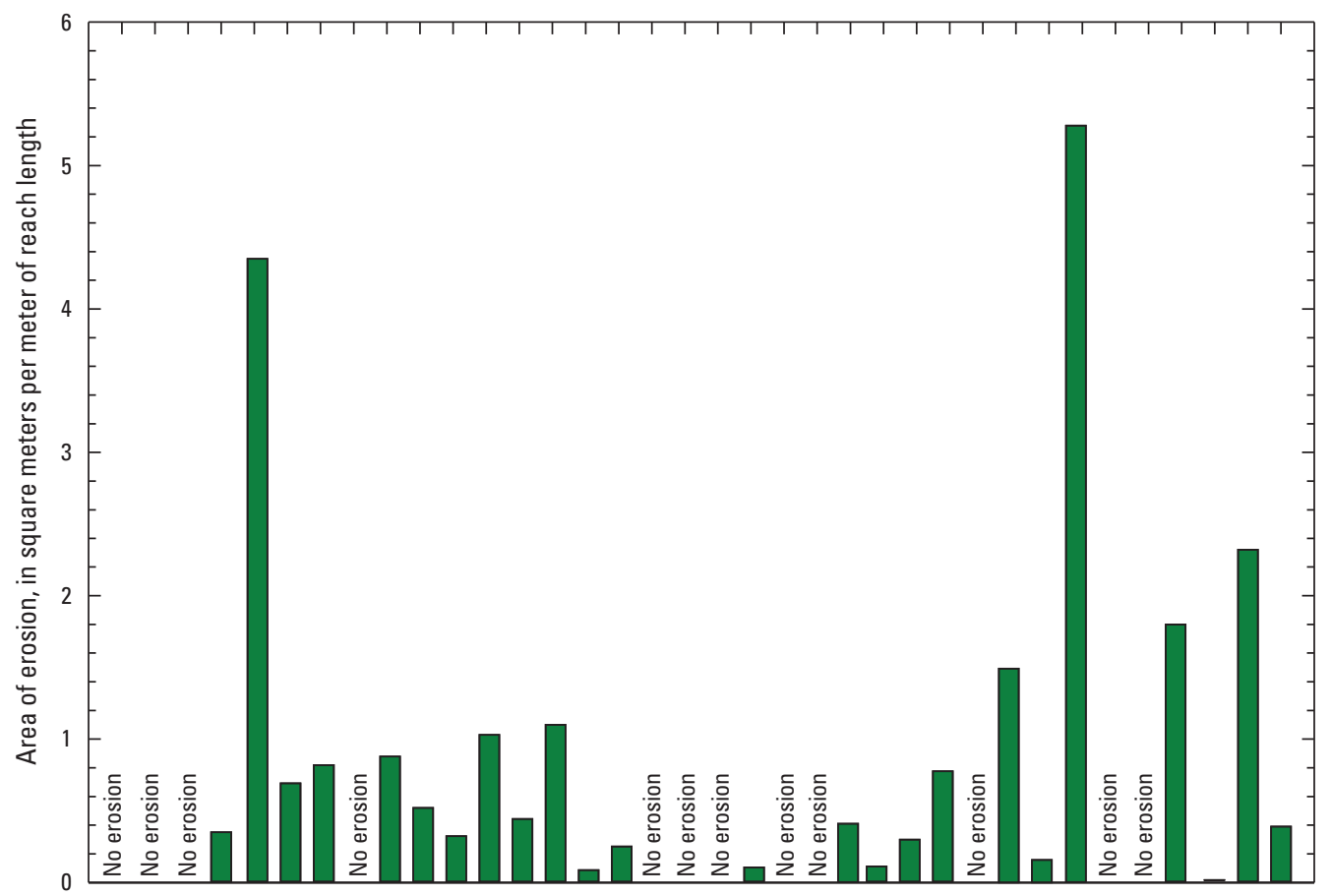

Figure 20. Area of eroding banks, terraces, and bluffs for 2013 intensive sites in the Duluth, Minnesota, area.

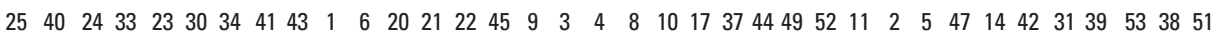
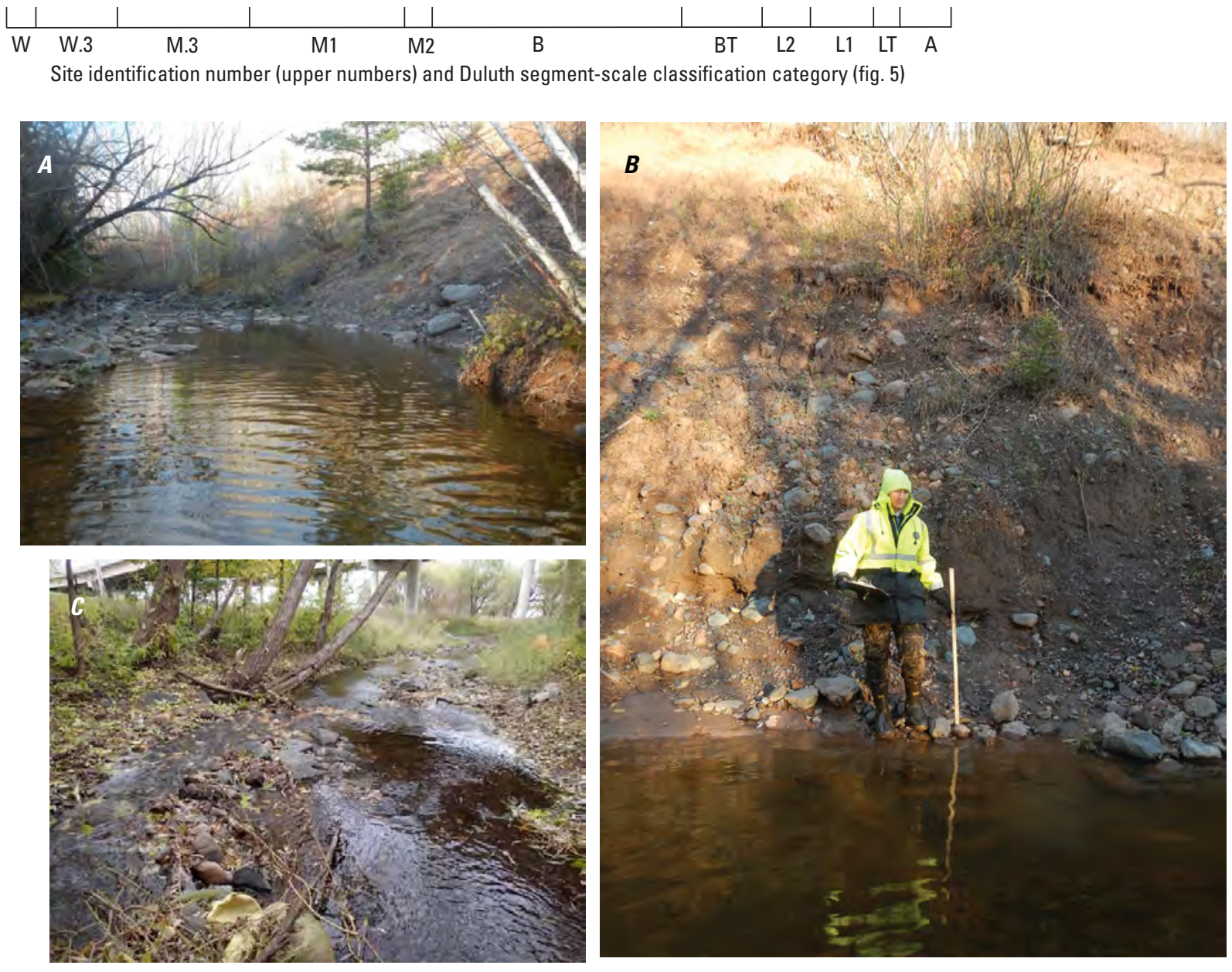

Figure 21. Comparison of erosion at selected sites in the Duluth, Minnesota, area. $A$ and $B$, site 14 (Amity Creek at Occidental Road, Amity Creek Park, Number 3) that had excessive bank erosion associated with the 2012 flood. C, site 42 (Keene Creek at Bristol Street) that did not have bank erosion. 


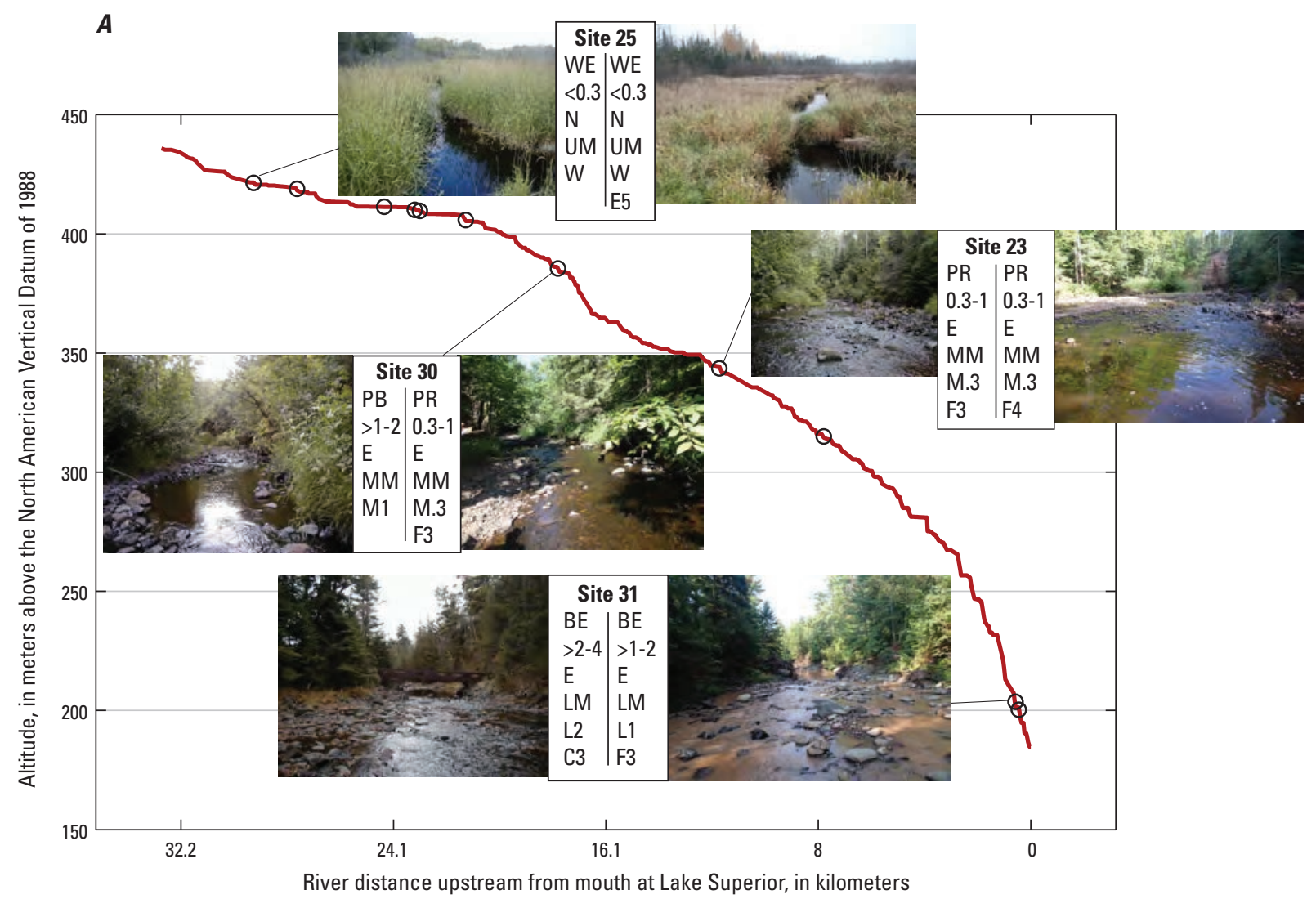

EXPLANATION

\begin{tabular}{|c|c|c|c|}
\hline \multicolumn{4}{|c|}{ Geomorphic assessment site identification number } \\
\hline 2003-4 classification & Site & 31 & 2013 classification \\
\hline Channel type (Fitzpatrick and others, 2006; table 2) & $\mathrm{BE}$ & $\mathrm{BE}$ & Channel type (table 4) \\
\hline Segment slope category, in percent (table 1-1) & $>2-4$ & $>1-2$ & Segment slope category, in percent (table 1-1) \\
\hline $\begin{array}{r}\text { Valley type (Fitzpatrick and others, 2006; fig. 6) } \\
\text { k position (Fitzpatrick and others, 2006; table 1-1) }\end{array}$ & $\begin{array}{l}\mathrm{E} \\
\mathrm{LM}\end{array}$ & $\begin{array}{l}\text { E } \\
\text { LM }\end{array}$ & $\begin{array}{l}\text { Valley type (Fitzpatrick and others, 2006; fig. 6) } \\
\text { Drainage network position (Fitzpatrick and others, 2006; table 1-1) }\end{array}$ \\
\hline egory (Fitzpatrick and others, 2006; table 2, fig. 5) & $\mathrm{L} 2$ & L1 & Duluth segment-scale classification category (table 1) \\
\hline Rosgen stream type (fig. 9) & C3 & F3 & Rosgen stream type (fig. 9) \\
\hline
\end{tabular}

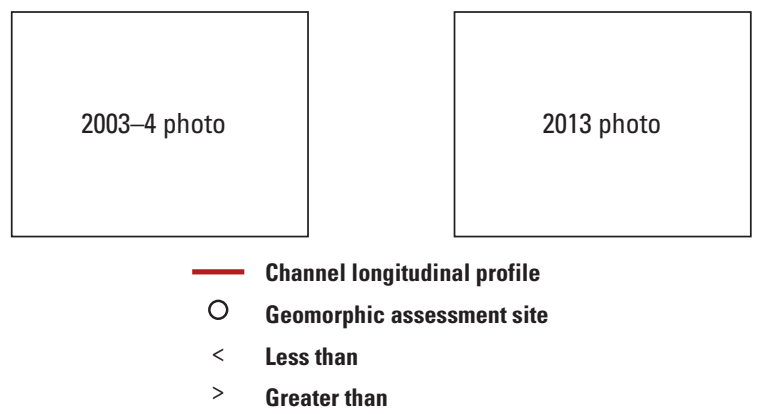

Figure 22. Longitudinal profiles with comparison photographs showing effects from the 2012 flood. $A$, Lester River. $B$, Miller Creek. $C$, Mission Creek. D, Keene Creek. 


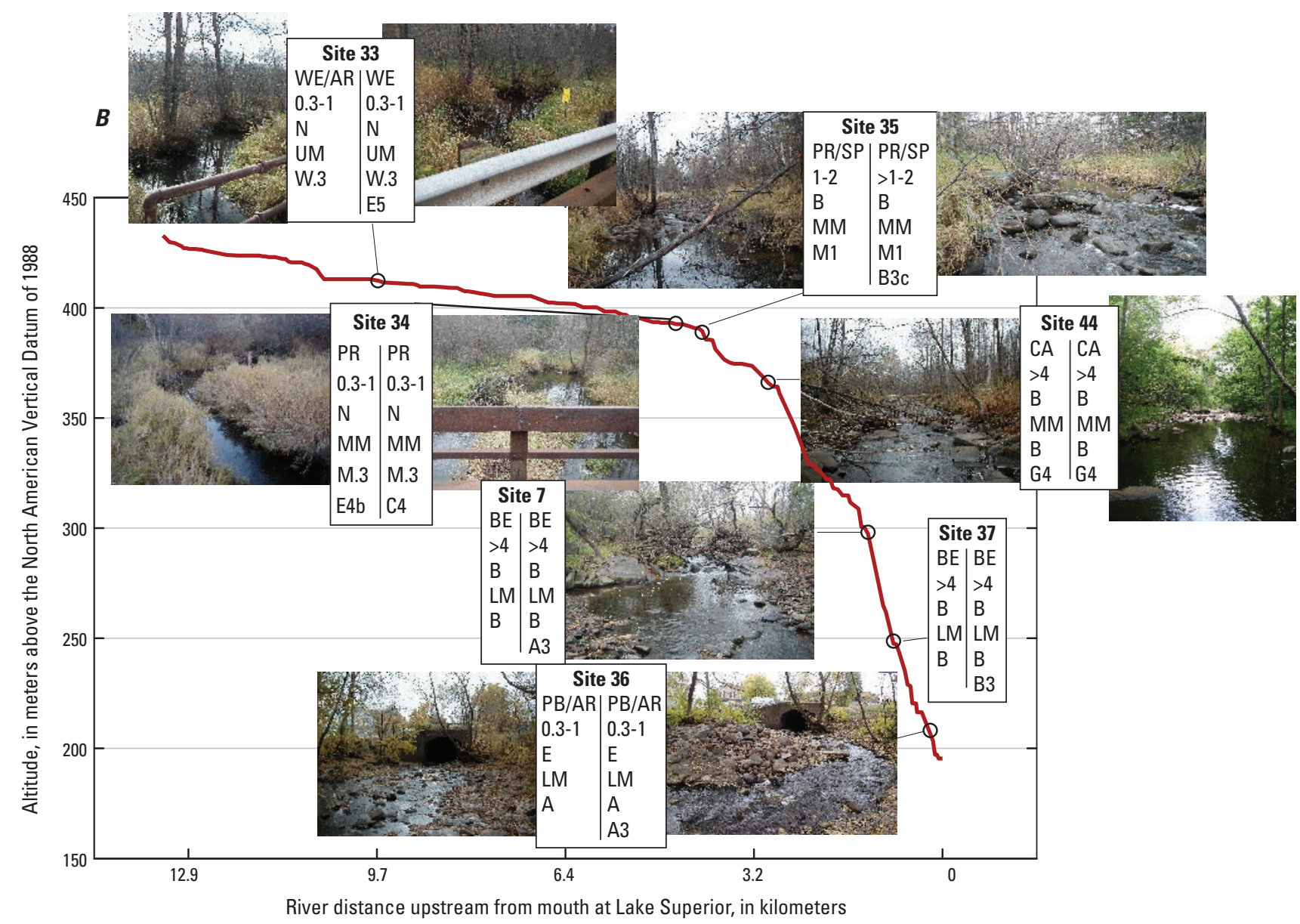

\section{EXPLANATION}

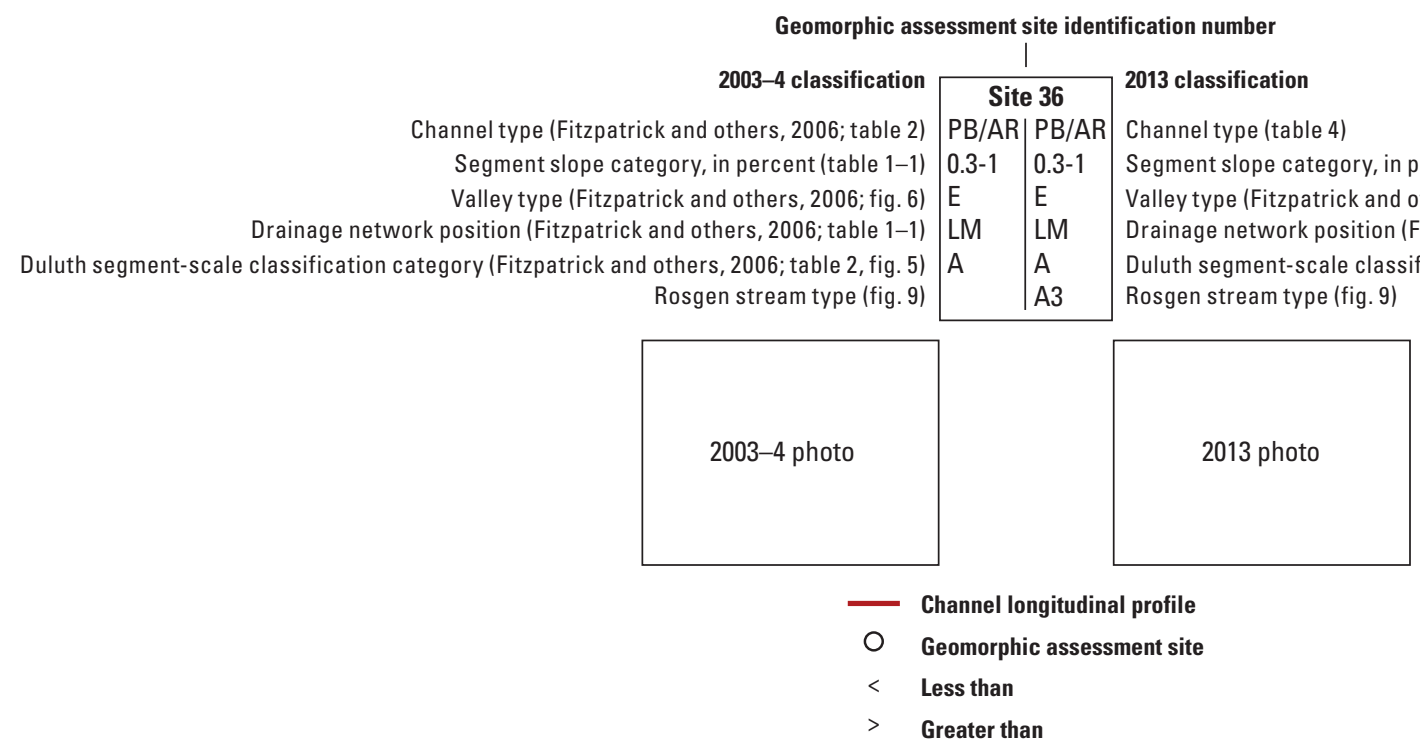

Figure 22. Longitudinal profiles with comparison photographs showing effects from the 2012 flood. $A$, Lester River. $B$, Miller Creek. $C$, Mission Creek. D, Keene Creek. 
C

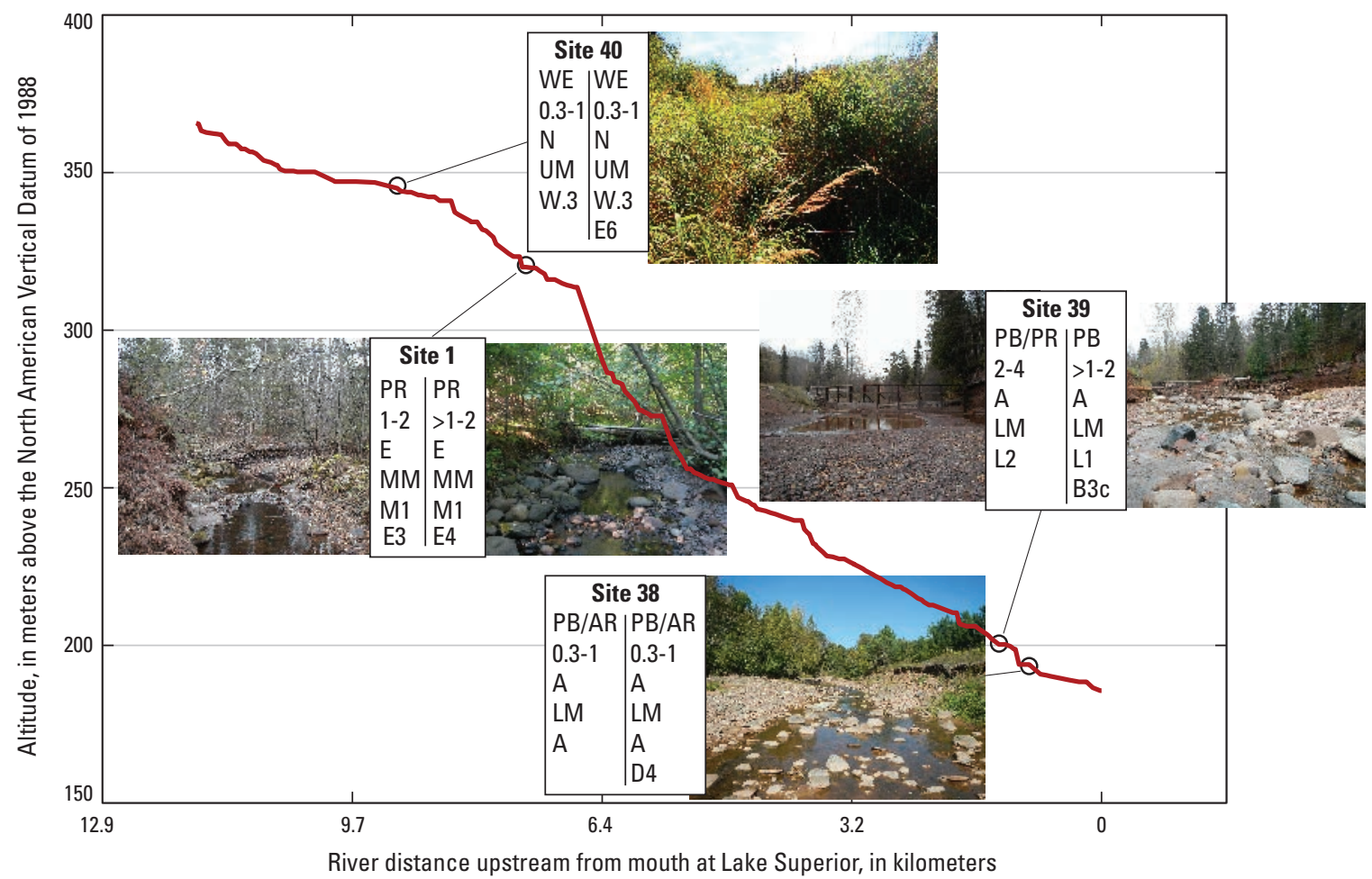

EXPLANATION

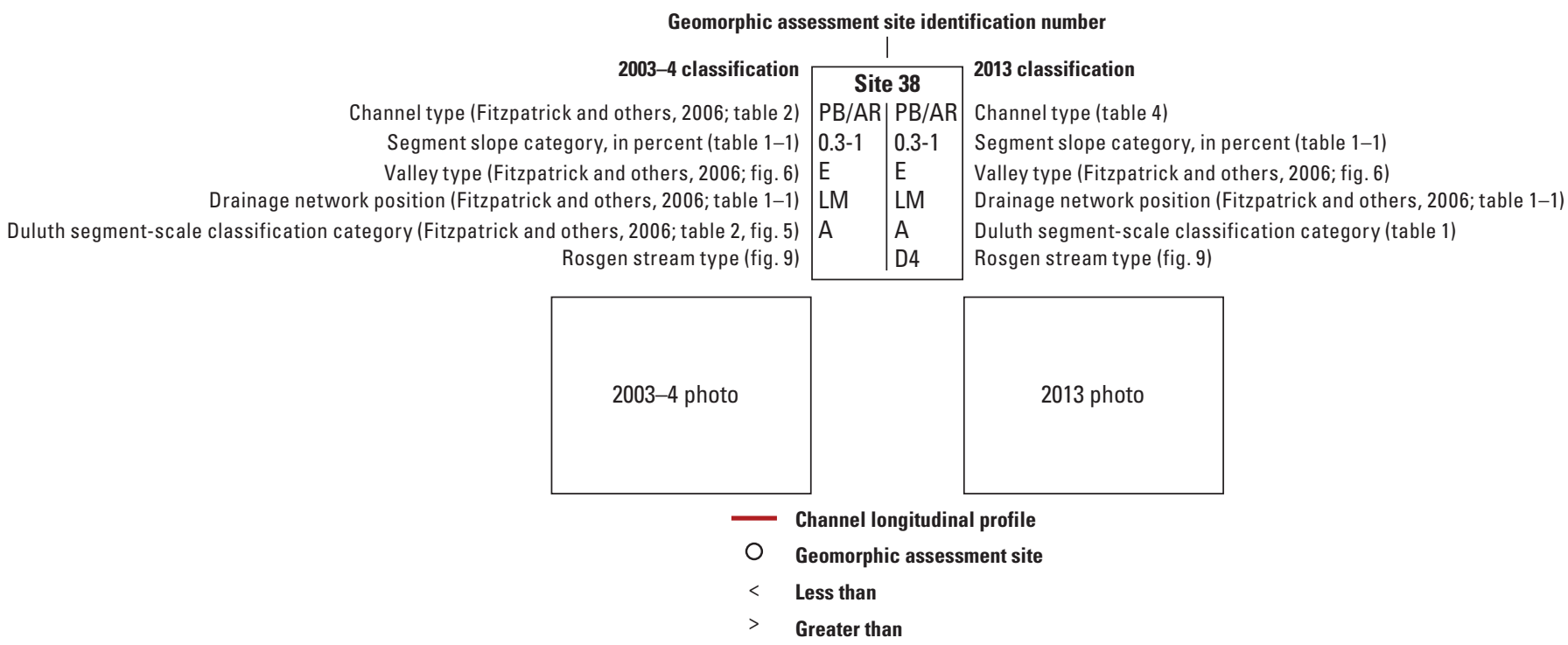

Figure 22. Longitudinal profiles with comparison photographs showing effects from the $2012 \mathrm{flood}$. $A$, Lester River. $B$, Miller Creek. $C$, Mission Creek. D, Keene Creek. 


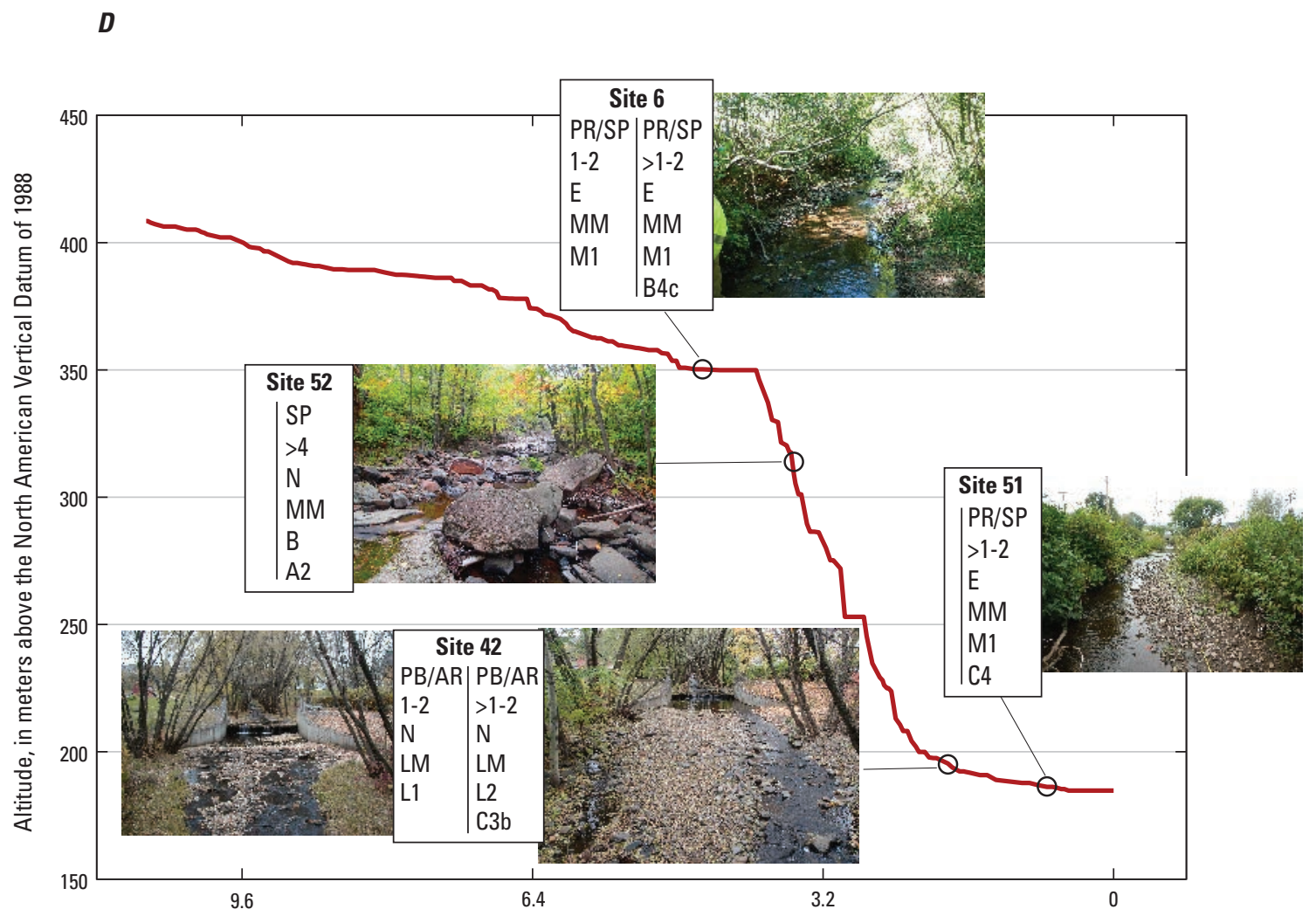

River distance upstream from mouth at Lake Superior, in kilometers

EXPLANATION

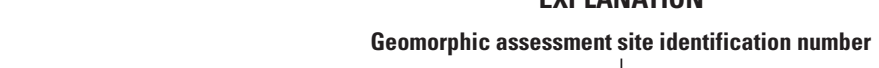

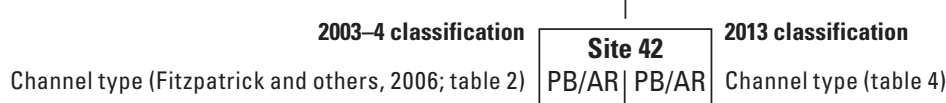

\begin{tabular}{l|l|l|l} 
Segment slope category, in percent (table 1-1) & $1-2$ & $>1-2$ & Segment slope category, in percent (table 1-1)
\end{tabular}

\begin{tabular}{l|l|l|l} 
Valley type (Fitzpatrick and others, 2006; fig. 6) & $\mathrm{N}$ & $\mathrm{N}$ & Valley type (Fitzpatrick and others, 2006; fig. 6)
\end{tabular}

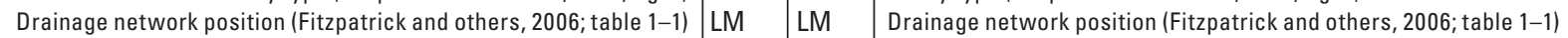

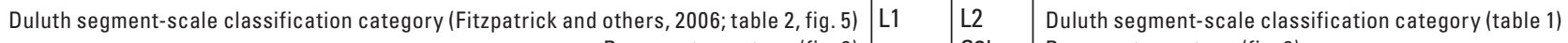

Rosgen stream type (fig. 9)

\begin{tabular}{l|l} 
L2 & Duluth segment-scale classific \\
C3b & Rosgen stream type (fig. 9)
\end{tabular}

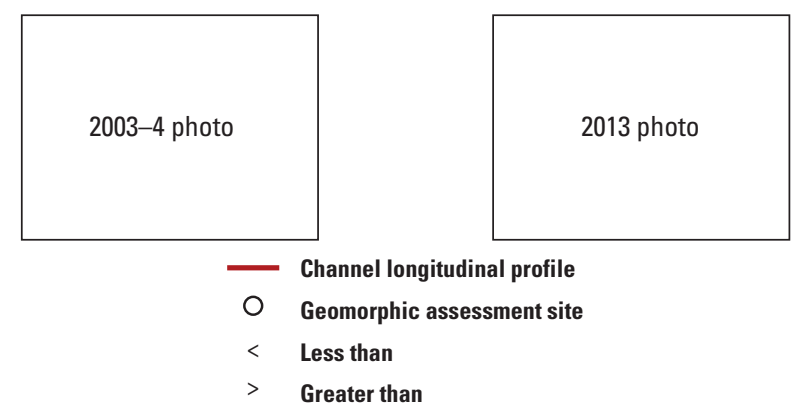

Figure 22. Longitudinal profiles with comparison photographs showing effects from the $2012 \mathrm{flood}$. $A$, Lester River. $B$, Miller Creek. $C$, Mission Creek. D, Keene Creek. 

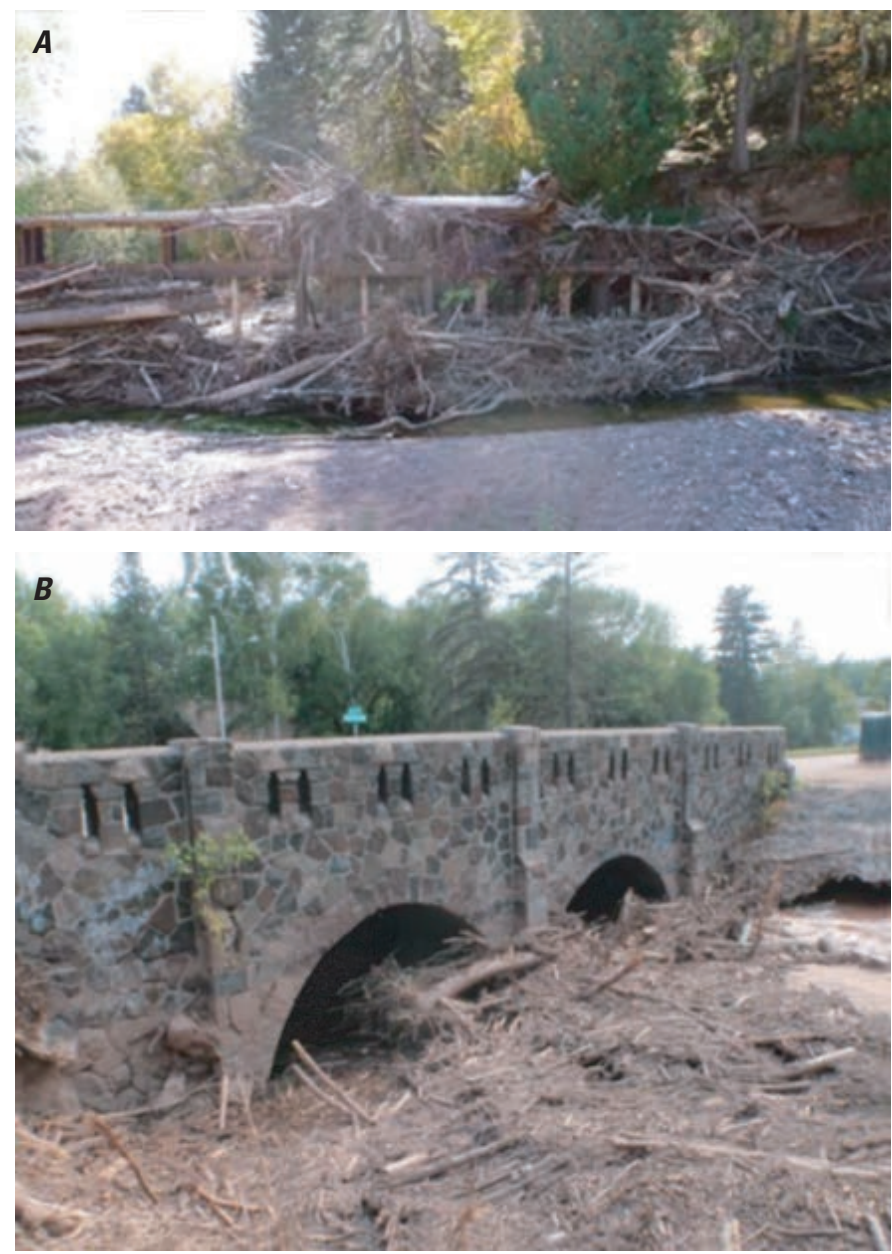

Figure 23. Large wood accumulation along Mission Creek after the 2012 flood. $A$, at the brush catcher. $B$, upstream side of bridge at State Highway 23 (Photographs by Molly Wick, Wisconsin Department of Natural Resources.)

\section{Implications for Infrastructure Repair and Future Rehabilitation}

One of the major outcomes of the 2012 flood was midchannel bar formation along main stems upstream from the many channel constrictions in the Duluth area, such as bridges and culverts. On a local scale, the buildup of coarse sediment during extreme events should be expected, given that the sampled sites were in urban areas with many stream crossings (fig. 24); thus, overwidened channels were formed from erosive flood flows and also from deposition of coarse sediment, such as was observed for the lower main stem of Mission Creek (fig. 12B). During future, more moderate floods, the presence of these bars may divert flows into banks and abutments, causing further bank erosion and widening, and possibly causing scour near bridge abutments. Large cobbles and boulders, and to some extent large deposits of gravel, will likely stay in place during moderate floods, especially if they become vegetated between floods. In situations like this where bank erosion is being driven by flow deflection around bars, removal of the bar material deposited in 2012 upstream from a bridge or culvert would likely protect bridge structures from future damage.

In more natural sites with known bluff erosion, it will be important to monitor channels that are locally migrating into the toes of bluffs because of bar formation. Once these bluffs become unstable, they can remain a large source of sediment into the future (Fitzpatrick and others, 1999, 2005). Runoff from hiking trails and storm sewers/street runoff along the tops of bluffs may contribute to additional erosion, mass wasting, and gullying.

The general geomorphic sensitivity categories associated with the 2003-4 Duluth-area segment-scale classification are only somewhat helpful in regard to potential negative effects from the 2012 flood on road infrastructure near stream crossings (fig. 24). As mentioned previously, middle main stems, bedrock, and lower main stems had locally specific bar deposition, which may affect subsequent flows in the vicinity of bridges and increase the potential for bank erosion and channel widening. In general, wetland segments W and W.3 had little geomorphic change and would keep their potential sensitivity as low to moderate. Middle main stems (segment categories M.3, M1, and M2) would remain the same at moderate to high sensitivity. Segment categories B, L2, and L1 had low to low/moderate sensitivity. In regard to the 2012 flood, these categories would instead have a range from low to high, with high sensitivity being locally specific. The segment category A already had a low to high range and would be the same in regard to the 2012 flood.

Large wood decreased in study sites after the 2012 flood throughout the Duluth area. There was already a lack of large wood noted in the 2003-4 assessments (Fitzpatrick and others, 2006). The changes in frequency, volume, and function of wood indicate a potentially wide-ranging negative effect on channel bedform diversity and the aquatic ecosystem (Beschta and Platts, 1983). Because much of the streams are still lined with mature trees, some wood will likely be replaced with time; thus, with time, some of the function of the wood should return. The immediate lack of wood available to trap sediment, however, also indicates a possible reduction in the stream's ability to mitigate sediment loads and a decrease in flow resistance (Cummins and Lauff, 1969; Beschta and Platts, 1986; Minshall, 1984; Montgomery and others, 1995). The loss of wood working to stabilize gravel bars will likely cause increases in coarse sediment transport rates during future floods and reduce stable substrate for benthic organisms. The postflood loss of pool volume also indicates a loss of associated aquatic habitat. Step-pool bedforms also dissipate erosive energy to downstream sites. In urban areas, large wood in streams is usually viewed as negative because it can block and damage culverts, bridges, and road crossings (fig. 23).

A summary of observed correspondence among the three classifications used in the Duluth area based on expected slope has some potential implications for stream restoration (table 5). The Duluth-area specific segment-scale 


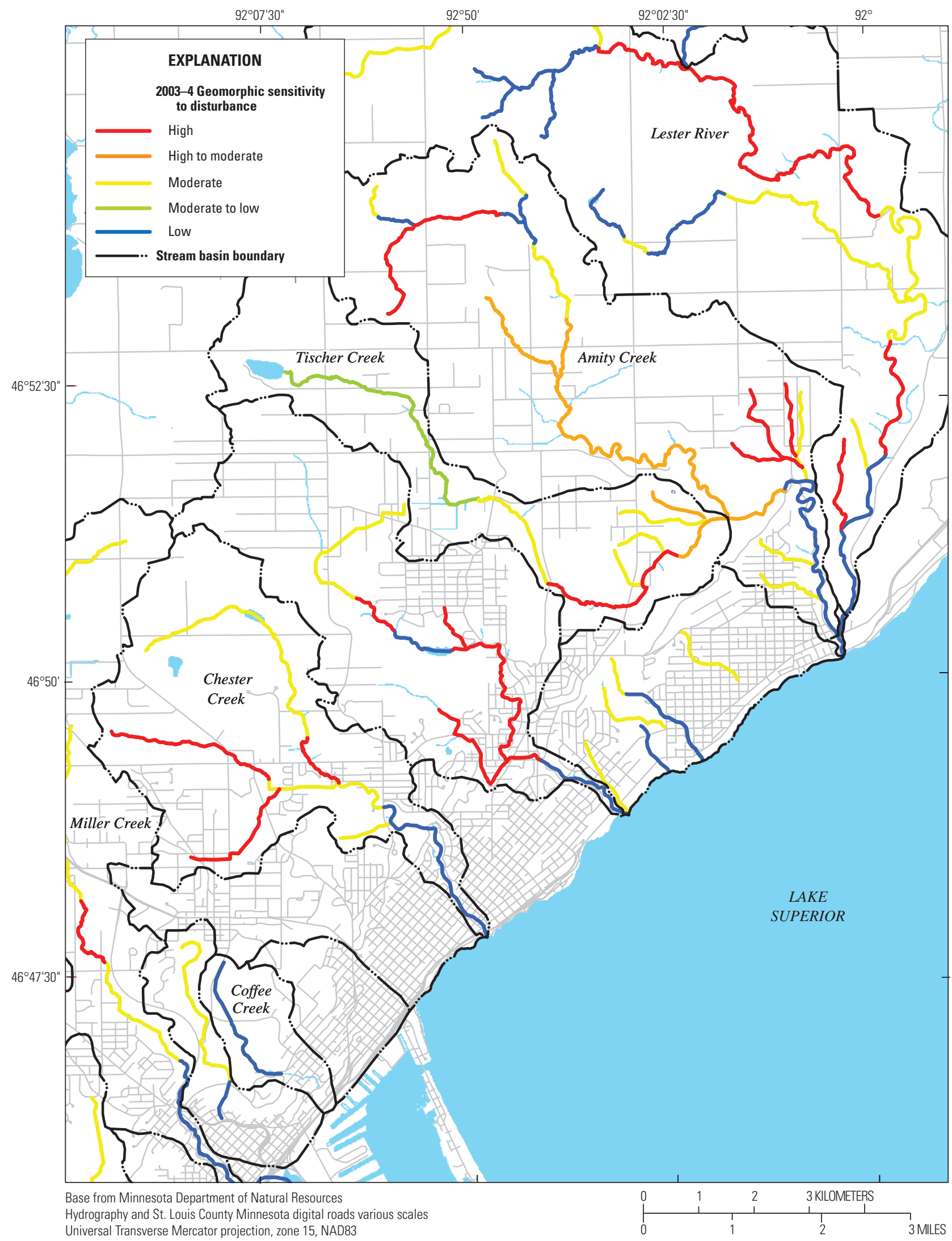

Figure 24. Overlay of roads in the Duluth, Minnesota, area with 2003-4 segment-scale classification by geomorphic sensitivity to disturbance (from Fitzpatrick and others, 2006). 
Table 5. Observed correspondence between the Duluth segment-scale classification (Fitzpatrick and others, 2006) and Duluth channel types and Rosgen Level II stream types for sites sampled in 2013 based on segment-averaged slope.

[Expected slope ranges, in percent, are shown in parentheses. Dark shading indicates expected correspondence, considering slope and position in the basin. $<$, less than; >, greater than; --, no site]

\begin{tabular}{|c|c|c|c|c|c|c|c|c|c|c|c|}
\hline & \multicolumn{11}{|c|}{ Number of sites in Duluth segment-scale classification category (fig. 5) } \\
\hline & $\underset{(<0.3)}{\mathbf{W}}$ & $\begin{array}{c}\text { W.3 } \\
(0.3-1)\end{array}$ & $\begin{array}{c}\text { M.3 } \\
(0.3-1)\end{array}$ & $\underset{(>1-2)}{M 1}$ & $\begin{array}{c}\text { M2 } \\
(>2-4)\end{array}$ & $\underset{(>4)}{B}$ & $\begin{array}{c}\text { BT } \\
(>4)\end{array}$ & $\begin{array}{c}\text { L2 } \\
(>2-4)\end{array}$ & $\begin{array}{c}\text { L1 } \\
(>1-2)\end{array}$ & $\begin{array}{c}\text { LT } \\
(>2-4)\end{array}$ & $\begin{array}{c}A \\
(0.3-1)\end{array}$ \\
\hline \multicolumn{12}{|c|}{ Duluth channel types (Fitzpatrick and others, 2006; modified Montgomery and Buffington, 1996) } \\
\hline Wetland $(<0.3-1)$ & 5 & 2 & -- & -- & -- & -- & -- & -- & -- & -- & -- \\
\hline Bedrock $(>8)$ & -- & -- & -- & -- & 1 & 8 & 2 & 1 & 3 & 1 & -- \\
\hline Colluvial (4-8) & -- & -- & -- & -- & -- & -- & 2 & -- & -- & -- & -- \\
\hline Cascade (4-8) & -- & -- & -- & -- & -- & 2 & 1 & -- & -- & -- & -- \\
\hline Step-pool (2-8) & -- & -- & -- & -- & -- & 1 & -- & -- & -- & -- & -- \\
\hline Planebed (1-4) & -- & 1 & 2 & 3 & -- & -- & -- & 2 & 4 & -- & 1 \\
\hline Pool-riffle (1-2) & -- & 1 & 3 & 4 & -- & -- & -- & -- & -- & -- & 1 \\
\hline \multicolumn{12}{|c|}{ Rosgen Level Il stream types (Rosgen, 1994; 1996) (fig. 9) } \\
\hline $\mathrm{A}(4-10+)$ & -- & -- & -- & -- & - & 5 & 4 & - & 6 & 1 & - \\
\hline $\mathrm{B}(<2-10)$ & -- & -- & -- & 3 & 1 & 5 & 1 & 2 & -- & -- & -- \\
\hline $\mathrm{C}(<0.1-4)$ & 2 & 3 & 1 & 3 & -- & -- & -- & 1 & -- & -- & 1 \\
\hline $\mathrm{D}(<0.1-4)$ & -- & -- & -- & -- & -- & -- & -- & -- & -- & -- & 1 \\
\hline $\mathrm{DA}(<0.5)$ & -- & -- & -- & -- & -- & -- & -- & -- & -- & -- & -- \\
\hline $\mathrm{E}(<2-4)$ & 3 & 1 & 2 & 1 & -- & -- & -- & -- & -- & -- & -- \\
\hline $\mathrm{F}(<2-4)$ & -- & -- & 2 & -- & -- & -- & -- & -- & 1 & -- & -- \\
\hline $\mathrm{G}(<2-4)$ & -- & -- & -- & -- & -- & 1 & -- & -- & -- & -- & -- \\
\hline
\end{tabular}

classification — based on mapping characteristics of drainage network position, slope, geologic setting, and valley typewas useful for describing geomorphic responses to the 2012 flood because it incorporated the local geologic setting and overall landform effects on the Duluth-area streams' specific longitudinal distribution of slope, substrate, and sediment transport characteristics. However, on the reach level, channel types and Rosgen stream types varied within segment categories, with some falling in the expected slope ranges and others not. Some of the variability in the correspondence is from local variability in the segment-averaged slope. Others are likely caused by local differences in coarse sediment supply and transport capacity.

In recognition of similar comparison studies among Rosgen Level II stream types $(1994,1996)$ and the Montgomery and Buffington (1997) channel types (Buffington and Montgomery, 2013), this study confirms the usefulness in looking at multiple classifications in terms of prioritizing sites that need immediate mitigation to protect urban infrastructure, less timecritical sites that likely will return to preflood conditions in a couple of decades, and sites that might benefit in the future for long-term urban-related rehabilitation. The complement of the modified Montgomery and Buffington (1997) channel types and Rosgen Level II $(1994,1996)$ stream types has usefulness for habitat and hydraulic applications; however, the quantitative reach-scale geomorphic measurements were necessary to describe the magnitude and spatial variability in geomorphic responses to an extreme flood, such as the one that hit the Duluth-area in 2012.

\section{Summary and Conclusions}

In 2013, the U.S. Geological Survey, in cooperation with the Minnesota Pollution Control Agency, completed a geomorphic assessment of 51 Duluth-area stream sites in 20 basins to describe and document the stream geomorphic changes associated with the June 2012 flood. Heavy rainfall caused flood peaks with annual exceedance probabilities of less than 0.002 (flood recurrence interval of greater than 500 years) on large and small streams in and surrounding the Duluth area. A geomorphic segment-scale classification previously developed in 2003-4 by the U.S. Geological Survey for Duluth-area streams was used as a framework to characterize the observed flood-related responses along a longitudinal continuum from headwaters to rivermouths at Lake Superior related to drainage network position, slope, geologic setting, and valley type. Field assessments in 2013 followed and expanded on techniques used in 2003-4 at intensive and rapid sites. A third level of assessment was added in 2013 to increase the 
amount of quantitative data at a subset of 2003-4 rapid sites. Characteristics of channel morphology, channel bed substrate, exposed bars and soft sediment deposition, large wood, pools, and bank erosion were measured; and repeat photographs were taken. Additional measurements in 2013 included identification of Rosgen Level II stream types.

Two types of channel classifications were used for the 2013 study that complemented the 2003-4 Duluth segmentscale geomorphic classification - a modified Montgomery and Buffington channel types that focused on channel bedforms and the Rosgen Level II stream types that focused on channel morphology. The two classifications, based on different scales and sources of geomorphic data, provide a reach-scale communication tool to help describe local geomorphic and sediment changes associated with system-wide geomorphic responses to the 2012 flood.

The 2003-4 Duluth, Minnesota, geomorphic segmentscale classification was useful for giving a larger spatial context and longitudinal continuum to help explain geomorphic responses to the June 2012 flood. The comparative analyses of field data collected in 2003-4 and again in 2013 indicated notable geomorphic changes, some of them expected and others not. A summary of findings related to the 2012 flood along the longitudinal continuum of segment categories is as follows:

- Gently sloping wetland streams in the headwaters remained relatively unchanged, with negligible changes in channel morphology or sediment dynamics.

- Middle main stems with entrenched valleys had widening and bank/bluff erosion. Gravel deposition and bar formation were locally common, indicating that sediment supply exceeded transport capacity, especially in sites with lower slopes or upstream from channel width constrictions.

- For bedrock streams, minor incision, bar formation, and bank/bluff erosion were observed in sites with a mix of bedrock and unconsolidated deposits.

- Lower main stem and alluvial streams had variable bank/bluff erosion, widening, bar formation, and aggradation. These sites had high amounts of coarse sediment transport rates during the 2012 flood, and any constrictions of the flood flows caused large depositional bar formation.

Overall, the proportion of gravel substrate increased as a result of more gravel supply to stream channels from local bank, terrace, and bluff erosion along middle main stem sites. Gravel bars formed during the 2012 flood will continue to affect channel morphology in the vicinity of infrastructure-related constrictions by causing local bank erosion, scour, and channel widening. There was a decrease in large wood and pools after the 2012 flood throughout the basins. This has immediate negative implications on stream habitat for fish and benthic invertebrates.
This study provided quantitative data from which to describe the geomorphic responses of Duluth-area streams to the catastrophic 2012 flood and documented spatially dependent effects on channel morphology, substrate, large wood, pools, and erosion. The 2013 data will serve as a baseline comparison for future monitoring of continued geomorphic responses and feedbacks from the large supply, transport, and deposition of coarse sediment during the 2012 flood. Results from this study can be used by local managers in postflood reconstruction efforts and provide baseline information for continued monitoring of geomorphic responses to the June 2012 flood.

\section{Acknowledgments}

The field work for the 2013 assessment was completed by two teams of technicians and scientists from the U.S. Geological Survey Minnesota and Wisconsin Water Science Centers (WSCs): Gerald Storey, Molly McCool, Joel Groten, and Erich Kessler from the Minnesota WSC; and Nick Buer, Joe Hoechst, and Kyle Raimer from the Wisconsin WSC. Scott Bennett, Chris Sanocki, Brent Mason, and John Lund from the Minnesota WSC assisted with developing geographic information system maps, diagrams, and associated analyses. Thorough technical reviews by Scott Anderson (Washington WSC) and Cynthia Rachol (Michigan WSC) are much appreciated and greatly improved the content of the report.

\section{References Cited}

Bent, G.C., and Waite, A.M., 2013, Equations for estimating bankfull channel geometry and discharge for streams in Massachusetts: U.S. Geological Survey Scientific Investigations Report 2013-5155, 62 p., accessed June 2, 2015, at http://dx.doi.org/10.3133/sir20135155.

Beschta, R.L., 1979, Debris removal and its effects on sedimentation in an Oregon Coast Range stream: Northwest Science, v. 53, no. 1, p. 71-77.

Beschta, R.L., 1983, The effects of large organic debris upon channel morphology - A flume study: Fort Collins, Colo., Simons, Li \& Associates, D.B. Simons Symposium on Erosion and Sedimentation [Proceedings], p. 8-63-8-78.

Beschta, R.L., and Platts, W.S., 1986, Morphological features of small streams - Significance and function: Journal of the American Water Resources Association, v. 22, no. 3, p. 369-379. [Also available at http://dx.doi. org/10.1111/j.1752-1688.1986.tb01891.x.] 
Buffington, J.M., and Montgomery, D.R., 2013, Geomorphic classification of rivers, in Shroder, J.F., and Wohl, Ellen, eds., Fluvial Geomorphology: San Diego, Calif., Academic Press, Treatise on Geomorphology, v. 9 , p. 730-767.

Cinotto, P.J., 2003, Development of regional curves of bankfull-channel geometry and discharge for streams in the non-urban, Piedmont Physiographic Province, Pennsylvania and Maryland: U.S. Geological Survey Water-Resources Investigations Report 03-4014. [Also available at https:// pubs.er.usgs.gov/publication/wri034014.]

Cummins, K.W., and Lauff, G.H., 1969, The influence of substrate particle size on the microdistribution of stream macrobenthos: Hydrobiologia, v. 34, no. 2, p.145-181. [Also available at http://dx.doi.org/10.1007/BF00141925.]

Czuba, C.R., Fallon, J.D., and Kessler, E.W., 2012, Floods of June 2012 in northeastern Minnesota: U.S. Geological Survey Scientific Investigations Report 2012-5283, 42 p. with 3 appendixes, accessed May 15, 2014, at http://pubs. usgs.gov/sir/2012/5283/.

Fitzpatrick, F.A., Knox, J.C., and Whitman, H.E., 1999, Effects of historical land-cover changes on flooding and sedimentation, North Fish Creek, Wisconsin: U.S. Geological Survey Water-Resources Investigations Report 99-4083, 12 p. [Also available at http://wi.water.usgs.gov/pubs/ WRIR-99-4083/.]

Fitzpatrick, F.A., Peppler, M.C., DePhilip, M.M., and Lee, K.E., 2006, Geomorphic characteristics and classification of Duluth-area streams, Minnesota: U.S. Geological Survey Scientific Investigations Report 2006-5029, accessed May 15, 2014, at http://pubs.usgs.gov/sir/2006/5029/.

Fitzpatrick, F.A., Peppler, M.C., Saad, D.A., Pratt, D.M., and Lenz, B.N., 2015, Geomorphic, flood, and ground-waterflow characteristics of Bayfield Peninsula streams, Wisconsin, and implications for brook trout rehabilitation: U.S. Geological Survey Scientific Investigations Report 20145007, 80 p. [Also available at http://dx.doi.org/10.3133/ sir20145007.]

Fitzpatrick, F.A., Peppler, M.C., Schwar, H.E., Hoopes, J.A., and Diebel, M.W., 2005, Monitoring channel morphology and bluff erosion at two installations of flow-deflecting vanes, North Fish Creek, Wisconsin, 2000-03: U.S. Geological Survey Scientific Investigations Report 2004-5272, 34 p. [Also available at http://pubs.usgs.gov/sir/2004/5272/.]

Fitzpatrick, F.A., Waite, I.R., D’Arconte, P.J., Meador, M.R., Maupin, M.A., and Gurtz, M.E., 1998, Revised methods for characterizing stream habitat in the National Water-Quality Assessment Program: U.S. Geological Survey WaterResources Investigations Report 98-4052, 67 p. [Also available at http://pubs.usgs.gov/wri/wri984052/.]
Gibson, R.J., Haedrich, R.L., and Wernerheim, C.M., 2005, Loss of fish habitat as a consequence of inappropriately constructed stream crossings: Fisheries, v. 30, no. 1, p. 10-17. [Also available at http://dx.doi.org/10.1577/15488446(2005)30[10:LOFHAA]2.0.CO;2.]

Goebel, J.E., Mickelson, D.M., Farrand, W.R., Clayton, L., Knox, J.C., Cahow, A., Hobbs, H.C., and Walton, M.S., Jr., 1983, Quaternary geologic map of the Minneapolis 4 degrees by 6 degrees quadrangle, United States: U.S. Geological Survey Miscellaneous Investigations Series, IMAP 1420(NL-15), scale 1:1,000,000.

Gurnell, A.M., Gregory, K.J., and Petts, G.E., 1995, The role of coarse woody debris in forest aquatic habitats: implications for management: Aquatic Conservation-Marine and Freshwater Ecosystems, v. 5, no. 2, p. 143-166. [Also available at http://dx.doi.org/10.1002/aqc.3270050206.]

Heede, B.H., 1972, Flow and channel characteristics of two high mountain streams: U.S. Department of Agriculture Forest Service, Research Paper, RM-96.

Helsel, D.R. and Hirsch, R.M., 2002, Statistical methods in water resources: U.S. Geological Survey Techniques of Water-Resources Investigations, book 4, chap. A3, 522 p.

Henning, William, 2011, User guidelines for single base real time GNSS positioning (ver. 2.1, August 2011): National Geodetic Survey, Positioning America for the Future, 131 p., accessed June 2, 2015, at http://www.ngs.noaa.gov/ PUBS_LIB/NGSRealTimeUserGuidelines.v2.1.pdf.

Hobbs, Howard, 2004, Late Wisconsinan Superior-Lobe deposits in the Superior Basin northeast of Duluth, in Severson, M.J., and Heinz, Julie, eds., Institute on Lake Superior Geology_Field Trip Guidebook: Institute on Lake Superior Geology, 50th, May 4-9, 2004, Duluth, Minn. [Proceedings], v. 50, pt. 2, p. 86-98.

Keller, E.A., and Swanson, F.J., 1979, Effects of large organic material on channel form and fluvial processes: Earth Surface Processes and Landforms, v. 4, p. 361-380.

Leverett, Frank, 1929, Moraines and shore lines of the Lake Superior Basin: U.S. Geological Survey Professional Paper 154-A, 72 p.

Lisle, T.E., 1986, Stabilization of a gravel channel by large streamside obstructions and bedrock bends. Jacoby Creek, northwestern California: The Geological Society of America Bulletin, v. 97, no. 8, p. 999-1011. [Also available at http:// dx.doi.org/10.1130/0016-7606(1986)97<999:SOAGCB>2. 0.CO;2.] 
Miller, J. D., Jr., Green, J.C., Severson, M.J., Chandler, V.W., and Peterson, D.M., 2001, Geologic map of the Duluth Complex and related rocks, northeastern Minnesota: Minnesota Geological Survey Miscellaneous Map Series M-119, scale 1:200,000 and 1:500,000.

Minnesota Department of Natural Resources, 2002, GAP land cover, tiled raster: Minnesota Department of Natural Resources, Division of Forestry, digital data, 30-meter resolution.

Minnesota Department of Natural Resources, 2015, Minnesota's Digital Elevation Project: Minnesota Department of Natural Resources Web page, accessed June 14, 2015, at http://www.dnr.state.mn.us/maps/lidar/index.html.

Minshall, G.W., 1984, Aquatic insect-substratum relationships, in Resh, V.H. and Rosenberg, D.M., eds., The Ecology of Aquatic Insects: New York, Praeger, p. 358-400.

Montgomery, D.R., and Buffington, J.M., 1993, Channel classification, prediction of channel response, and assessment of channel condition: Washington State Timber/Fish/Wildlife, Report TFW-SH10-93-002, 84 p.

Montgomery, D.R., and Buffington, J.M., 1997, Channelreach morphology in mountain drainage basins: The Geological Society of America Bulletin, v. 109, no. 5, p. 596-611. [Also available at http://dx.doi.org/10.1130/00167606(1997)109<0596:CRMIMD>2.3.CO;2.]

Montgomery, D.R., and Buffington, J.M., 1998, Channel processes, classification, and response, in Naiman, R.J., and Bilby, R.E., eds., River ecology and management—Lessons from the Pacific Coastal ecoregion: New York, SpringerVerlag, Inc., p. 13-42.

Montgomery, D.R., Buffington, J.M., Smith, R.D., Schmidt, K.M., and Pess, George, 1995, Pool spacing in forest channels: Water Resources Research, v. 31, no. 4, p.1097-1105. [Also available at http://dx.doi.org/10.1029/94WR03285.]

National Oceanic and Atmospheric Administration, 2008, Lidar 101-An introduction to lidar technology, data, and applications: Charleston, S.C., National Oceanic and Atmospheric Administration, Coastal Services Center, 61 p., accessed June 15, 2015, at https://coast.noaa.gov/data/digitalcoast/pdf/lidar-101.pdf

Rosgen, D.L., 1985, A stream classification system, riparian ecosystems and their management-Reconciling conflicting uses: Fort Collins, Colo., Rocky Mountain Forest and Range Experiment Station RM-120, p. 91-95.

Rosgen, D.L., 1994, A classification of natural rivers: Catena, v. 22, p. 169-199.

Rosgen, D.L., 1996, Applied river morphology: Pagosa Springs, Colo., Wildland Hydrology Books, 351 p.
Rosgen, D.L., 2001, A stream channel stability assessment methodology: Proceedings of the Seventh Federal Interagency Sedimentation Conference, March 25-29, 2001, Reno, Nevada, p. II-18-II-26.

Rosgen, D.L., Silvey, H.L., and Frantila, D., 2008, River stability field guide: Pagosa Springs, Colo., Wildland Hydrology Books, $244 \mathrm{p}$.

Rosgen, D.L., 2009, Watershed Assessment of River Stability and Sediment Supply (WARSSS): Fort Collins, Colo., Wildland Hydrology Books, 628 p.

Rydlund, P.H., Jr., and Densmore, B.K., 2012, Methods of practice and guidelines for using survey-grade global navigation satellite systems (GNSS) to establish vertical datum in the United States Geological Survey: U.S. Geological Survey Techniques and Methods, book 11, chap. D1, 102 p. with appendixes. [Also available at http://pubs.usgs.gov/ $\mathrm{tm} / 11 \mathrm{~d} 1 /$.]

Saunders, J.W., and Smith, M.W., 1962, Physical alteration of stream habitat to improve brook trout production: Transactions of the American Fisheries Society, v. 91, no. 2, p. 185-188. [Also available at http://dx.doi.org/10.1577/15488659(1962)91[185:PAOSHT]2.0.CO;2.]

Simon, Andrew, and Hupp, C.R., 1992, Geomorphic and vegetative recovery processes along modified stream channels of west Tennessee: U.S. Geological Survey Open-File Report 91-502, 142 p. [Also available at http://pubs.usgs. gov/of/1991/ofr_91-502/.]

Smith, R.D., Sidle, R.C., and Porter, P.E., 1993, Effects on bedload transport of experimental removal of woody debris from a forest gravel-bed streams: Earth Surface Processes and Landforms, v. 18, no. 5, p. 455-468. [Also available at http://dx.doi.org/10.1002/esp.3290180507.]

Sullivan, Kathleen, Lisle, T.E., Dolloff, C.A., Grant, G.E., and Reid, L.M., 1987, Stream channels-The link between forests and fishes, in Salo, E.O., and Cundy, T.W., Streamside management-Forestry and Fishery Interactions: Proceedings of a symposium held at the University of Washington, February 12-14, 1986, p. 39-97.

St. Louis County Minnesota, 2014, Mapping applicationsGIS web mapping applications to explore county data: St. Louis County Minnesota Web page, accessed June 14, 2015, at http://www.stlouiscountymn.gov/LANDPROPERTY/ Maps/MappingApplications.aspx.

University of Minnesota-Duluth Geology Department, Minnesota Geological Survey, and Minnesota Department of Natural Resources, 1997, Geomorphology of Minnesota: digital data, scale 1:100,000.

Thorne, C.R., 1998, Stream reconnaissance handbook: Chichester, West Sussex, John Wiley and Sons, 133 p. 
U.S. Geological Survey, 2016, National Water Information System-USGS 04015300 Knife River near Two Harbors, MN: accessed June 24, 2016, at http://waterdata.usgs.gov/ $\mathrm{mn} /$ nwis/uv?site_no=04015330.

Wolman, M.G., 1954, A method of sampling coarse river-bed material: Transactions of the American Geophysical Union, v. 35, no. 6, p. 951-956.

Young, B.M., Fitzpatrick, F.A., and Blount, J.D., 2015, Stream geomorphic and habitat data from a baseline study of Underwood Creek, Wisconsin, 2012: U.S. Geological Survey Data Series 947, 14 p., plus data files. [Also available at http://dx.doi.org/10.3133/ds947.] 

Appendixes 1-4 


\section{Appendix 1. Summary of Duluth-Area Segment Classification Characteristics at the 51 Study Sites, 2013}

A summary of Duluth-area segment classification characteristics at the 512013 study sites and slope comparison to the 2003-4 assessments are presented in table 1-1 as a Microsoft巴 Excel spreadsheet available at http://dx.doi.org/10.3133/ sir20165104. The spreadsheet contains additional segmentscale information for drainage network position, valley type, bedrock type, glacial landform/deposits, and dominant land cover. Notes on changes in segment or channel type designation also are included. A list of abbreviations used in table 1-1 are included as a worksheet named “Abbreviations.”

Table 1-1. Summary of Duluth-area segment characteristics at the 512013 study sites and slope comparison to the 2003-4 study sites.

\section{Appendix 2. Reach Maps of Intensive Sites}

This appendix contains Portable Document Format (PDF) files of reach maps for the 20 intensive assessments in 2013 (figs. 2-1 through 2-20, available at http://dx.doi.org/10.3133/ sir20165104); intensive assessments were completed at 8 of these sites in 2003-4. The maps contain survey points for reference marks, benchmarks, Globel Positioning System, cross sections, and longitudinal profiles. Reach boundaries are included. Light detection and ranging from 2012 is provided as a backdrop.

Figure 2-1. Reach map for intensive assessment at site 1, Mission Creek at Stenman Road, Duluth, Minnesota, 2013 and 2003-4.

Figure 2-2. Reach map for intensive assessment at site 6, Keene Creek at Skyline Road, Duluth, Minnesota, 2013.

Figure 2-3. Reach map for intensive assessment at site 10, Tischer Creek at Skyline Road and Vermillion Road, Duluth, Minnesota, 2013.

Figure 2-4. Reach map for intensive assessment at site 11, Amity Creek at Occidental Road, Lester Park, Duluth, Minnesota, 2013.

Figure 2-5. Reach map for intensive assessment at site 23, Lester River at North Tischer Road, Duluth, Minnesota, 2013 and 2003-4.
Figure 2-6. Reach map for intensive assessment at site 25, Lester River at Arnold Road, Number 1, Duluth, Minnesota, 2013 and 2003-4.

Figure 2-7. Reach map for intensive assessment at site 30, Lester River at Highway 37, Jean Duluth Road, Duluth, Minnesota, 2013 and 2003-4.

Figure 2-8. Reach map for intensive assessment at site 31, Lester River near Lester River Road, Duluth, Minnesota, 2013 and 2003-4.

Figure 2-9. Reach map for intensive assessment at site 33, Miller Creek at Swan Lake Road, Duluth, Minnesota, 2013.

Figure 2-10. Reach map for intensive assessment at site 34, Miller Creek upstream from Chambersburg Avenue, Duluth, Minnesota, 2013 and 2003-4.

Figure 2-11. Reach map for intensive assessment at site 37, Miller Creek at 10th Street, Duluth, Minnesota, 2013.

Figure 2-12. Reach map for intensive assessment at site 38, Mission Creek at Highway 23, Duluth, Minnesota, 2013.

Figure 2-13. Reach map for intensive assessment at site 40, Mission Creek at Helburg Road, Duluth, Minnesota, 2013.

Figure 2-14. Reach map for intensive assessment at site 43, Chester Creek at Triggs Road, Duluth, Minnesota, 2013 and 2003-4.

Figure 2-15. Reach map for intensive assessment at site 44, Miller Creek at Lake Superior College, Duluth, Minnesota, 2013 and 2003-4.

Figure 2-16. Reach map for intensive assessment at site 45, U.S. Steel Creek upstream from Highway 23, Duluth, Minnesota, 2013.

Figure 2-17. Reach map for intensive assessment at site 49, Kingsbuy Creek downstream from Interstate 35, Duluth, Minnesota, 2013.

Figure 2-18. Reach map for intensive assessment at site 51, Keene Creek between Grand Avenue and 59th Avenue West, Duluth, Minnesota, 2013.

Figure 2-19. Reach map for intensive assessment at site 52, Keene Creek upstream from Highland Avenue, Duluth, Minnesota, 2013.

Figure 2-20. Reach map for intensive assessment at site 53, Coffee Creek upstream from Arlington Road, Duluth, Minnesota, 2013. 


\section{Appendix 3. Data Associated with Cross-Section and Longitudinal Profiles at Intensive Sites}

This appendix contains data associated with cross-section and longitudinal profiles for the 20 sites at which intensive assessments were completed in 2013; intensive assessments were completed at 8 of these sites in 2003-4. The data are presented in a Microsoft ${ }^{\circledR}$ Excel spreadsheet for each of the 20 sites available at http://dx.doi.org/10.3133/sir20165104. Within each spreadsheet are five worksheets. The first worksheet is named "Abbreviations" and contains explanations for the abbreviations used in the other four worksheets. The second worksheet is named "RawData," and presents the raw data collected for the channel topographic cross sections and longitudinal profiles using electronic total stations or real-time network global positioning systems from the U.S. Geological Survey Wisconsin or Minnesota Water Science Centers. The second worksheet is named "RawToUTMconversion," and contains the conversion of the raw data into real world coordinates of Universal Transverse Mercator (UTM), Zone 16 coordinates.

The fourth worksheet is named "Cross Sections" and contains data and graphical plots of channel cross sections for the 2013 intensive assessment and for the 2003-4 assessment if an assessment was completed. Three to seven channel cross sections were surveyed at each intensive site. These cross sections characterized typical riffles, runs, and pools. Semipermanent benchmarks (rebar stakes) were established at each cross section. Topographic survey points, usually about 20 points along a transect, included terrace and flood-plain altitudes if necessary, tops of banks, bankfull altitudes, bank slopes, channel toe, channel bed and thalweg, or any other major change in slope. Some of the transects are listed as "abbreviated," which means they contain fewer points, usually nine, for left and right top of banks, left and right bankfull stage, left and right water's edge, left and right bank toe, and thalweg.

The fifth worksheet is named "Longitudinal Profile," and contains the water surface and thalweg profiles for the 2013 intensive assessment and for the 2003-4 assessment if an intensive assessment was completed. Water-surface and channel thalweg points were surveyed along the reach, with points taken at intervals of one channel width as well as at all local slope breaks. These long profiles were used to compute water surface and streambed slopes from riffle to riffle and for the reach. Regression equations are presented for the slope for each profile (Helsel and Hirsch, 2002).

\section{Reference Cited}

Helsel, D.R. and Hirsch, R.M., 2002, Statistical methods in water resources: U.S. Geological Survey Techniques of Water-Resources Investigations, book 4, chap. A3, 522 p.

\section{Appendix 4. Summary of Field Assessment Data for Each Site}

This appendix contains a summary of field assessment data for reaches in the 2013 assessment. The field assessment data are presented in a Microsoft $\AA$ Excel spreadsheet containing five worksheets available at http://dx.doi.org/10.3133/ sir20165104. The first worksheet is named "Abbreviations," which is a list of abbreviations used in the appendix 4 tables.

The second worksheet is table $4-1$, which provides a summary of reach geomorphic characteristics and processes at the 51 study reaches in the 2013 assessment and comparison to the 2003-4 assessment. The third worksheet is table 4-2, which presents channel morphology and substrate metrics and resulting Rosgen Level II stream types for 2013. Comparable stream types for 2003-4 data are included in table 4-2. The fourth worksheet is table 4-3, which is a summary of bankfull width and depth for the 20 sites with intensive assessments in 2013. The fifth worksheet is table 4-4, which presents streambed particle size and rank for the 20 sites with intensive assessments in 2013.

Table 4-1. Summary of reach geomorphic characteristics and processes at the 51 study reaches in the 2013 assessment and comparison to the 2003-4 assessment.

Table 4-2. Channel morphology and substrate metrics and resulting Rosgen Level II stream types for 2013. Comparable stream types for 2003-4 data are included for comparison.

Table 4-3. Summary of bankfull width and depth for the 20 sites with intensive assessments in 2013.

Table 4-4. Streambed particle size data and rank used to calculate Rosgen Level II stream types for 19 of the 20 sites with intensive assessments in 2013. 
Publishing support provided by:

Rolla Publishing Service Center

For more information concerning this publication, contact: Director, USGS Minnesota Water Science Center

2280 Woodale Drive

Mounds View, Minnesota 55112

(763) 783-3100

Or visit the Minnesota Water Science Center Web site at: http://mn.water.usgs.gov/ 



\section{通}

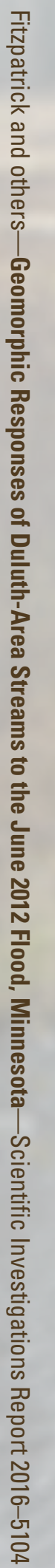

